Министерство образования и науки Республики Казахстан Западно-Казахстанский инновационно-технологический университет

КУЗНЕЦОВА А.Н.

\title{
Диалог: содержание и форма педагогической деятельности
}

Уральск, 2021 
Рецензенты:

Пересветов H.H. - кандидат педагогических наук, профессор кафедры педагогики ЗКИТУ.

Собянин Ф.И. - доктор педагогических наук, профессор ЗКИТУ

Кузнецова А.Н.

Диалог: содержание и форма педагогической деятельности./ А.Н. Кузнецова - Уральск: Полиграфсервис, 2021. - 112 с.

\section{ISBN}

В монографии представлен анализ теоретических и эмпирических исследований диалогического взаимодействия. Проблема диалога рассмотрена автором с точки зрения зарубежных и отечественных исследователей, произведено соотнесение понятия «диалог» и «диалоговое обучение» с родственными категориями философской и психологической науки, выделены основные характеристики диалогического воздействия и факторы, влияющие на процесс диалогического обучения. Культура диалога рассматриваются в аспекте педагогических технологий в лингвистике с позиций имплицитности, эксплицитности и аргументативности в межкультурной коммуникации, моделирования ценностных ориентиров в социальном дискуссионном диалоге.

Работа адресована всем, кто интересуется проблемами современного социогуманитарного знания, кто стремится к поиску средств продуктивного межкультурного диалога - преподавателям, студентам, магистрантам.

$$
\text { УДК }
$$

ББК

ISBN
Глоссарий с комментариями

и примерами

Введение …………........................................................... 8

Глава 1. Формирование диалоговых умений учащихся в современной педагогической литературе, практике творчески работающих учителей ....

Глава 2. Виды и типы обучающего диалога ....

Глава 3. Методы и приемы обучения монологической и диалогической речи

Глава 4. Собственный педагогический опыт формирования диалоговых умений обучащихся среднего звена общеобразовательного учреждения

Заключение

Выводы .87

Список использованной и рекомендованной литературы 105

Приложения 112

(C) Кузнецова А.Н., 2021 


\section{ГЛОССАРИЙ}

Коммуникативная культура - система знаний, норм, ценностей и образов поведения, принятых в обществе, и умение органично, естественно и непринужденно реализовывать их в деловом и эмоциональном общении

Общение - взаимодействие двух или более людей, состоящее в обмене между ними информацией.

Коммуникация - сообщение, передача информации посредством речи или иных знаковых систем в процессе взаимодействия.

Монолог - речь одного лица, обращенная к слушателю или к самому себе.

Беседа - разговор, обмен мнениями.

Группа-собраниелюдей, включённых впознавательнокоординированную деятельность, сознательно или бессознательно подчинённую общей цели.

Диалог - (от греческого разговор, беседа) -

1) форма устной речи, разговор двух или нескольких лиц; речевая коммуникация посредством обмена репликами в отличии от монолога как речи одного говорящего;

2) (перен.) переговоры, свободный обмен мнениями.

Рефлексия - свойство человеческого мышления, которое направлено на осмысление собственной деятельности, критический анализ её.

Дискуссия - спор, обсуждение какого-нибудь вопроса на собрании, в печати, в беседе.

Основная цель современного школьного образования - целостное и многоаспектное развитие личности школьника, его социальная адаптация, эффективная реализация в сфере будущей профессиональной деятельности. Необ- ходимым условием успешной социализации, интеллектуального и эмоционального развития личности является повышение общей и коммуникативной культуры. Разработанные единые государственные образовательные стандарты обращают особое внимание на развитие коммуникативной компетенции школьников - способности человека решать языковыми средствами те или иные коммуникативные задачи в разных сферах и ситуациях общения. Использование языка как средства общения требует от говорящего знания многих правил и норм, которые должен учитывать носитель языка. Где, когда, что, как говорят, какое значение придается отдельным словам и выражениям в зависимости от конкретных обстоятельств - все это регулируется коммуникативной компетенцией.

Коммуникативная культура - одно из определяющих свойств человека двадцать первого века.

Коммуникативная культура представляет собой систему знаний, норм, ценностей и образов поведения, принятых в обществе, и умение органично, естественно и непринужденно реализовывать их в деловом и эмоциональном общении.

Коммуникативная культура выражается в умении устанавливать гуманистические, личностноориентированные взаимоотношения с другим человеком. Понятие «коммуникативная культура» представлено рядом компонентов:

- способность к согласованию и соотнесению своих действий с другими, принятию и восприимчивости других, подбору и предъявлению аргументов, способность к выдвижению альтернативных объяснений, обсуждению проблемы, пониманию и уважению мнений других;

- потребность в другом как партнере коммуника- 
ции, к расширению границ коммуникаций, к сопоставлению точек зрения;

- готовность к гибкому тактичному взаимоотношению с другим, к рефлексивной деятельности, к проектированию коммуникативных умений и применению их в новой ситуации.

В диалоге осуществляются важнейшие проявления человеческих отношений:

- взаимоуважение,

- взаимодополнение,

- взаимообогащение,

- взаимопонимание

- сопереживание,

- сотворчество.

Отмечаем, что в настоящее время коммуникативная культура рассматривается лингвистами как понятие многозначное. Применительно к задачам обучения русского языка и литературы в школе следует говорить о воспитании языковой личности, владеющей нормами русского литературного языка, обладающей даром слова, т.е. способной правильно воспринимать устную и письменную речь, свободно пользоваться словом для выражения своих мыслей и чувств в устной и письменной форме, соблюдающей этические нормы общения.

В педагогике в настоящее время диалог признается как особая ценность; рассматривается как средство формирования субъект-субъектных отношений; используются понятия «культура диалога», «диалогическая компетентность», тезисы: «диалог - педагогический принцип формирования коммуникативной компетентности учащихся», «диалог - базовый принцип коммуникативного содержания образования»; разрабатываются диалогиче- ские технологии обучения (текстуально-диалогическая образовательная технология, технология проблемнодиалогического обучения, технология); разрабатываются различные диалогические подходы в образовании.

Уже несколько лет ведущей в моей педагогической деятельности является работа по формированию коммуникативной культуры обучающихся. Накопленным материалом я бы хотелась поделиться.

Перед вами определения понятий, которые будут иметь непосредственное отношение к теме научного исследования, освящённом в монографии.

- Взаимодействие двух или более людей, состоящее в обмене знаковых систем в процессе взаимодействия. (Коммуникация)

- Речь одного лица, обращенная к слушателю или к самому себе. (Монолог)

- Разговор, обмен мнениями. (Беседа)

- Собрание людей, включённых в познавательнокоординированную деятельность, сознательно или бессознательно подчинённую общей цели. (Группа)

- (От греческого «разговор, беседа») - ) форма устной речи, разговор двух или нескольких лиц; речевая коммуникация посредством обмена репликами в отличии от монолога как речи одного говорящего;) (перен.) переговоры, свободный обмен мнениями. (Диалог)

- Свойство человеческого мышления, которое направлено на осмысление собственной деятельности, критический анализ её. (Рефлексия)

- Спор, обсуждение какого-нибудь вопроса на собрании, в печати, в беседе. (Дискуссия) 


\section{ВВЕДЕНИЕ}

Красноречие, умение правильно, выразительно и точно говорить всегда было необходимой частью культуры личности, красноречие формировалось в процессе обучения и высоко ценилось. Сегодня важным результатом происходящих изменений в понимании учебного процесса является использование диалога в педагогической деятельности. Объективной предпосылкой обращения к диалогу участников процесса обучения выступает соответствующий отбор и построение содержания образования

Диалог, по мнению авторов краткого словаря иностранных слов - это разговор между двумя или несколькими лицами. Это обобщенное мнение двух и более людей, которое все больше и больше получает распространение, как метод обучения в современных общеобразовательных школах. Авторы краткого психологического словаря считают, что диалог - это попеременный обмен репликами двух и более людей. Эта форма общения была распространена в философских и научных произведениях античности и Нового времени (Платон, Дидро, Ксенофонт и др.). Значение диалога для школьной психологии и педагогики заключается в том, что у ребенка диалог представляется универсальной составляющей речевого общения. Близкое к этим суждениям мы встречаем в высказываниях авторов БСЭ т. 8, которые считают, что диалог - это вид речи, характеризующийся ситуативностью (зависимостью от обстановки).

Диалог всегда противопоставляется монологу. Из сказанного, видимо следует, что научных изданиях и популярной литературе мы, к сожалении, пока не встре- чаем единства мнений авторов. Однако это не снимает остроты и актуальности проведения дальнейшего научного поиска по выработке методических рекомендаций для специалистов по поиску оптимальных путей обучения учащихся диалогу, диалоговой речи на уроках языковых дисциплин в современной общеобразовательной школы. Анализ школьной практики позволил нам обнаружить противоречие, состоящее в том, что диалог как идеальная форма, идеальная цель (вербализованная в представлениях учителей) и диалог как реальное деятельностное воплощение цели - это два не совпадающих друг с другом феномена. Данное противоречие позволило сформулировать проблему исследования: педагоги испытывают потребность в диалоге как новой идеальной форме обучения, но не владеют технологией его организации в своей профессиональной деятельности. Связанная с этим ситуация непроявленности приемов организации диалога в педагогической практике обусловлена, с одной стороны, проблемой неосознанного (непрофессионального) отношения педагогов к организации учебного процесса, с другой - неразработанностью приема как особой педагогической категории в научной литературе. Даже тогда, когда педагоги осознанно подходят к построению совместной деятельности на уроке, они часто соотносят педагогические приемы с разным содержанием деятельности: идентифицируя свою деятельность с диалогом, вносят в ее содержание ценностно-соподчинительную связь (Е.Н. Ильин); отождествляют с «монстростроительством» (С.Ю. Курганов) или проблемным обучением (К.Г. Митрофанов) и т.п.

Неотрефлексированность педагогических приемов организации диалога для педагогов, обращающихся к нему 
в своей педагогической практике, отсутствие существенных признаков, позволяющих фиксировать диалог в реальном педагогическом процессе, приводит к подмене его «псевд од налогом», который принципиально ничего в образовательной практике не меняет. Это обстоятельство дискредитирует диалог и лишает перспективы его развития в учебном процессе.

Анализ научной литературы убеждает нас в том, что выявленное противоречие обнаруживает себя и на теоретическом уровне. В философских исследованиях диалог представляет собой «выяснение, актуализацию, формирование ценностных смысловых позиций друг друга» (Б.А. Пархонский); определяется как смыслообразующий, смыслотворческий процесс, «передача смысла себя» (В.И. Кабрин); «державный принцип человеческого существования» (В.С. Библер); «центральная метафора» современной культуры (Н.А. Безменова); «особое системное целое» (В.А. Дмитриенко). Обращение к диалогу связано со сменой научных парадигм (А.П. Огурцов, Е.Ф. Тарасов), с существованием иной «матрицы», иного типа мышления (Т.Г. Григорьева), с анализом текста или культуры (А.А. Брудный, Ю.М. Лотман). Диалог трактуется как «мгновенное, «сиюминутное» высказывание (А. Шлегель); «разговор с глазу на глаз» (Г. Гадамер) и рассматривется как «устная речь, протекающая в условиях непосредственного контакта» (И.В. Нестеров).

В психологических работах диалог определяется как «взаимопонимание, основанное на интуиции, импровизации, на равноправии действующих и взаимоотносящихся сторон, опирающихся на наличие альтруистических и эмпатийных особенностей личности» (Ю. Кушнер, А. Маслоу, К.Г. Митрофанов, Т.К. Мухина, К.Роджерс); «не просто обмен информацией, а взаимодействие его участников» (А.А. Бодалев, А.С. Спиваковская); «составляющий компонент сотрудничества, выступающий как двусторонний процесс» (Т.А. Флоренская, А.У. Хараш); «возрождение живого слова» (Т.Г. Григорьева), возникновение «мы-реакции», «мы-решения» (А.К. Болотова); связывается с определенного рода поведением (Н.А. Исаева, К.Н. Поливанова, В.И. Слободчикова) и с заложенным в нем механизмом саморазвития

И.А. Костенченко). При этом обращение к диалогу обусловлено стремлением «очеловечить», оживить учебный процесс. Исследованию диалога как особого рода деятельности, обнаруживающей субъектность педагога и ребенка посвящены работы крупнейших отечественных психологов (Л.С. Выготский, В.В. Давыдов, А.Н. Леонтьев, Д.Б. Эльконин). Однако в собственно педагогическом контексте проблема диалога разработана, на наш взгляд, недостаточно глубоко.

Обращение к педагогической литературе позволило нам зафиксировать различные теоретические направления, пути анализа диалога в культуре, различные способы деятельности в нем, условия и механизмы его реализации; обнаружить исследования природы, сущностных характеристик, функций диалога. Диалог рассматривается в нескольких аспектах: как особая форма подачи культурологических знаний, позволяющая поместить ребенка в культуру прошлой эпохи, «спор нескольких образов мира» (С.Ю. Курганов); спор равноправных собеседников (В.В. Сериков, Г.В. Левин); диалог культур (культуры учителя и ученика) (В.Э. Тамарин); способ преодоления ряда «антиномий» процесса обучения (Ю.В. Сенько), реализации проблемного обучения (Э.Н. Недзвицкая, В. 
Казанская); «творческая свобода в русле заданной темы» (Е.Н. Ильин); реализация партнерских оснований в деятельности (Г.Г. Гранин, В.Н. Куницына). Под диалогом понимают не только форму обучения, но и метод исследования личности ребенка (В .А- Сухомлинский), «возможность личностного становления» (К.Г. Митрофанов); отождествляют с активными методами обучения, игровым моделированием (Е.В. Кучерова), с эвристическим приемом усвоения монологического знания (Ю.И. Зуев); рассматривают не только как один из моментов обучения, но и как неотъемлемый компонент технологии обучения (В.В. Сериков); специальным образом организованную ситуацию общения (В. Казанская); самую простую нерасчлененную форму взаимодействия В.П. Долматов), аргументацию, защиту своей собственной позиции и выработку совместного решения (Г.В. Левин).

Сущность диалогического общения видят в общении равноправных субъектов (Н.А. Ильина, В.В. Иванов), связывая представление о диалоге с особой формой и целостной моделью совместной деятельности, с одним из способов соорганизации участников совместной деятельности педагога и учащихся (Г.Н. Прозументова, Е.Н. Ковалевская); рассматривают как смыслообразующий, смыслотворческий процесс, «передачу смысла себя» (В.И. Кабрин); как «особое системное целое» (В.А. Дмитриенко). Однако, несмотря на то, что диалогическое отношение «пронизывает» весь процесс обучения, целенаправленного, специального приобщения учащихся к диалогу не ведется (Ю.В. Сенько). Почти во всех изученных нами подходах практически не встречается каких-либо конкретных технологий, методик организации диалога, не указываются возможные пути его реа- лизации в учебном процессе; не обнаруживается реальных оснований, с помощью которых можно выделить педагогические приемы, адекватные диалогу как особой по содержанию и форме педагогической деятельности. Очевидным является то, что диалог как педагогическая форма пока еще не осмыслен и не описан: под его содержанием понимают все ту же традиционную передачу знаний, поэтому методика его организации напоминает методику традиционного урока. Все это обусловливает необходимость разработки диалога в учебном процессе на уровне его технологий. 


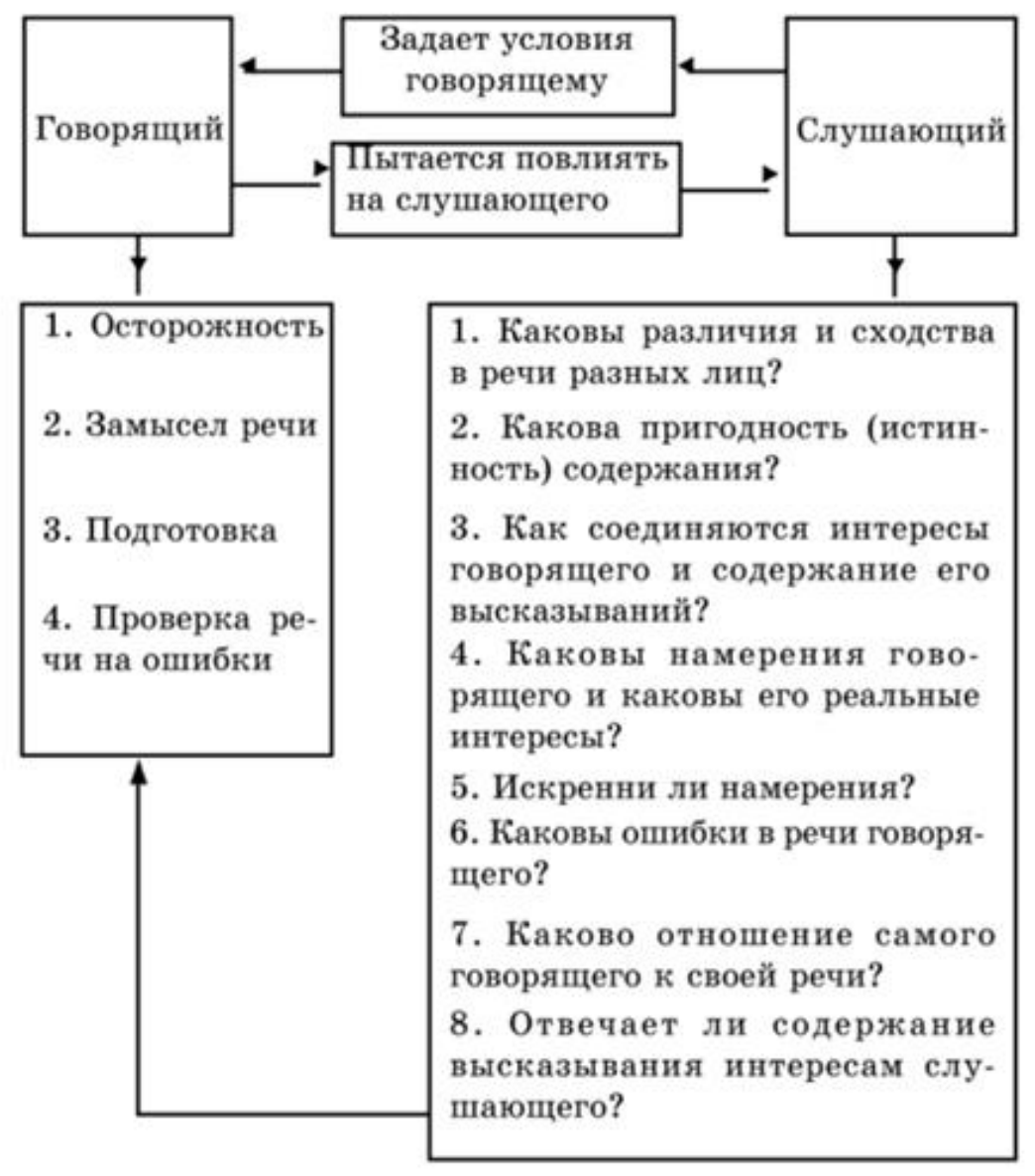

Рисунок 1. Алгоритм действий говорящего и слушающего.
ГЛАВА 1.

\section{Формирование диалоговых умений} учащихся в современной педагогической литературе, практике творчески работающих учителей

Считается, что в Европе в систематическое использование диалог, как независимую литературную форму ввёл Платон: указывают на его ранние эксперименты с жанром,который сицилийские поэты Софрон и Эпихарм культивировали на половину столетия ранее. Эти работы, которыми восхищался и которым подражал Платон, не сохранились, но учёные воображают и представляют их как сыгравших небольшую роль, обычно представляя только этих двух исполнителей. Мим Герод может дать нам некоторое представление о сфере, в которой они работали.

Платон ещё более упростил эту форму и свёл её к чисто аргументированному разговору, не затронув при этом забавный элемент - играющих персонажей. По всей видимости, он начал работать с этим жанром около 405 года до н. э. и к 400-му году он совершенствуется в диалоге, особенно в связи с Сократом, который, правда, уже умер к тому времени, но который считался мастером этого жанра. Все его философские сочинения, кроме Апологии, используют эту форму.

После Платона диалог стал основным литературным жанром в античности, в котором были написаны некоторые значимые работы на латинском и греческом языках. Так, вскоре после Платона Ксенофонт написал свою работу - Пир; а Аристотель написал несколько философских диалогов в стиле Платона, ни один из которых, к со- 
жалению, не сохранился. После этого в большинстве эллинистических (философских) школ появились свои собственные диалоги. Цицерон написал несколько очень важных диалогов, среди которых - Оратор, Республика, а также работу, которая была утеряна - Гортензия (последняя цитируется Августином как работа, которая привила ему пожизненную любовь к философии).

Таблица 1. Устная дописьменная речь.

\begin{tabular}{|l|l|c|}
\hline \multicolumn{3}{|c|}{ Устная дописьменная речь. } \\
\hline \multicolumn{1}{|c|}{ Диалог } & \multicolumn{1}{|c|}{ Молва } & \multicolumn{1}{|c|}{ Фольклор } \\
\hline $\begin{array}{l}\text { Ораторика (запрет на } \\
\text { воспроизведение текста) }\end{array}$ & $\begin{array}{l}\text { Сценическая речь(запрет на } \\
\text { различие между написанным } \\
\text { и устным текстом) }\end{array}$ \\
\hline $\begin{array}{l}\text { Гомилетика } \\
\text { (запрет на исчерпание содержания } \\
\text { в одном выступлении) }\end{array}$ & \\
\hline
\end{tabular}

\begin{tabular}{|c|c|c|}
\hline $\begin{array}{l}\text { Судебная речь } \\
\text { (запрет на речь } \\
\text { не о конкретных } \\
\text { событиях и лицах) }\end{array}$ & $\begin{array}{l}\text { Совещательная } \\
\text { речь (запрет } \\
\text { на отсутствие } \\
\text { прогноза о } \\
\text { событиях) } \\
\end{array}$ & $\begin{array}{l}\text { Показательная речь } \\
\text { (Запрет на } \\
\text { неупоминание текущих } \\
\text { событий) }\end{array}$ \\
\hline $\begin{array}{l}\text { Учебная речь } \\
\text { (запрет на } \\
\text { невведение нового } \\
\text { материала) }\end{array}$ & $\begin{array}{l}\text { Проповедь } \\
\text { (запрет на } \\
\text { упоминание } \\
\text { кого-либо из } \\
\text { аудитории) }\end{array}$ & $\begin{array}{l}\text { Пропаганда } \\
\text { (запрет на неосвещение } \\
\text { текущих актуальных } \\
\text { событий) }\end{array}$ \\
\hline
\end{tabular}

В английской не драматургической литературе диалог не получил широкого распространения до тех пор, пока Беркли не использовал его в 1713 году в своём трактате. Три диалога между Гиласом и Филонусом. Воображаемые 16 разговоры Лэндора (1821-1828) являются наиболее известным английским примером диалога в XIX веке, хотя диалоги сэра Артура Хэлпса также привлекали к себе внимание и были популярными.В Германии Виланд использовал эту форму для нескольких важных сатирических произведений, опубликованных между 1780 и 1799 гг. Итальянские писатели коллекционировали (собирали) диалоги, следуя модели Платона,

Платонический диалог, как отдельный жанр, в котором проявились особенности Сократа как говорящего с одним или с несколькими собеседниками и обсуждался некий философский вопрос, возродился в некоторых литературных опытах в XX веке.

Философские диалоги, с Сократом и без него, как персонажем, по-прежнему используется от случая к случаю философами при попытках писать привлекательные и философские литературные произведения, попытках схватить тонкие нюансы и живой обмен в дискурсе в том виде, в каком они действительно имеют место в интеллектуальном разговоре.

Мартин Бубер придал диалогу ключевую позицию в своей теологии. В своей наиболее влиятельной работе, озаглавленной I and Thou (Я и Ты), он заботливо выращивает и продвигает сквозь всю работу диалог, но не как целенаправленную попытку сделать выводы или просто выразить точку зрения, но как необходимейшее условие подлинных отношений между человеком и человеком, человеком и Богом. Его озабоченность глубинной природой подлинного диалога привела к так называемой философии диалога.

Русский философ и семиотик Михаил Михайлович Бахтин теорией диалога подчёркивал власть дискур- 
са, углубляющего понимание множества перспектив и точек зрения и создание бесчисленного множества возможностей. Бахтин считал, что всё живое взаимосвязано, и поэтому диалог создаёт новое понимание для ситуаций, которые требуют изменения. В своих значимых работах Бахтин выстроил лингвистически-философскую методологию определения диалога, его природы и значения: ${ }^{[7]}$

Диалогические отношения имеют специфическую природу: они не могут быть редуцированы ни до чисто логических (даже если это диалектические), ни до лингвистических (композиционно-синтаксических) отношений. Они возможны только между завершёнными высказываниями различающихся говорящих субъектов... Там где нет слов и нет языка, не может быть никаких диалогических отношений; они не могут существовать среди объектов и логических величин (понятий, суждений и т. д.). Диалогические отношения предполагают язык, но они не живут в системе языка. Они невозможны между элементами языка

Согласно А. Ф. Копьеву, у М. М. Бахтина можно выделить два взаимосвязанных значения понятия диалог: первое более общее, состоит в том, что диалог - это некоторая общечеловеческая реальность, условие формирования сознания человека и второе более узкое значение: диалог как событие общения человека

Бразильский педагог Паулу Фрейре, известный вкладом в развитие народного образования, развивал теорию диалога как метода педагогики. Фрейре отмечал, что ведение диалоговой коммуникации в среде, характеризующейся уважением и равенством, позволяет учащимся и учителям учиться друг у друга. Великий защитник угне- тённых людей, Фрейре применял на практике принцип диалога, который выявляет и связывает ценности людей. Педагогика диалога ориентирована на более глубокое понимание, на разработку неких позитивных изменений в мире.

Сегодня принцип диалога используется в школах, общественных центрах, корпорациях, федеральных агентствах, а также другие социальных образованиях и институтах, позволяя людям, как правило, в небольших группах, делиться своим видением и опытом относительно сложных вопросов и проблем. Диалогический подход используется для того, чтобы помочь людям решать давние конфликты и выстраивать более глубокое понимание спорных вопросов. Диалог - это не судейство, не взвешивание и принятие решений, а понимание и обучение. Диалог опровергает стереотипы, создает доверие и позволяет людям быть открытыми к перспективам, которые сильно отличаются от их собственных.

В последние 2-3 десятилетия по всему миру развиваются быстрорастущие движения в поддержку диалога. Так, например, в Америке появилась Национальная коалиция за диалог и обсуждение. Появляются группы и организации (например, Worldwide Marriage Encounter; Retrouvaille), помогающие людям, находящимся в браке, гармонизировать свои отношения через обучение диалогическому методу, который помогает людям в паре узнать больше друг о друге без «угрожающих поз».

Диалог - это деликатный процесс. Множество препятствий тормозит диалог и способствует конфронтации, такой, как дискуссия и дебаты. Общими препятствиями являются страх, показ или осуществление власти, недоверие; внешние влияния, отвлечения и плохие усло- 
вия коммуникации могут препятствовать любому развитию диалога

Равноправный диалог - это одна из его форм, которая происходит, когда различные участники диалога рассматриваются скорее с точки зрения справедливости (обоснованности, вескости) их аргументов, их содержания, чем с точки зрения оценки мощности и власти тех позиций, которые они занимают, и которые их защищают.

Структурированный диалог представляет собой вид диалогических практик, разработанных как средство ориентации, направления диалогического дискурса к проблеме понимания и согласования действия. Большинство традиционных диалогических практик не структурированы или частично структурированы и потому недостаточно помогают в выяснении различных перспектив и точек зрения в проблемной области. Дисциплинированная, организованная форма диалога, в которой участники соглашаются следовать определённой структуре, организации, или содействию, упрощению, позволяет группам решать сложные проблемы и разделять между участниками результаты того общего решения.

Алеко Христакис и Джон Н. Варфилд были разработчиками новой школы диалога .Основанием для привлечения структурированного диалога является анализ демократической формы диалога, осуществляемый снизу вверх. Оно свидетельствует о том, что диалог должен быть структурирован, что позволит ему обеспечить достаточное разнообразие заинтересованных сторон и, как следствие, представит проблему системно. Это также позволит сбалансировать голоса заинтересованных сторон и участников в ходе диалогического процесса. Под техникой общения или коммуникативной техникой понимают совокупность средств(приёмов),используемых людьми для формирования желательных эффектов в процессе общения. Средства общения разделяются на словесные (вербальные) и несловесные ( невербальные). Словесная техника состоит из способов организации текста и риторических приёмов. Несловесные компоненты техники включают в себя мимику, пантомимику (позы, жесты), контакт глаз тон, темп и интонацию речи, а также пространственно-временную организацию коммуникативной ситуации.

Ряд авторитетных специалистов в области коммуникации считают, что владение невербальными компонентами техники более важно для установления желательных отношений, чем владение вербальными компонентами. Даже если это и не совсем верно, точнее говоря, верно не для всех коммуникативных ситуаций, акцент на невербальную составляющую общения оправдан тем, что в повседневной жизни ей уделяется меньше внимания, чем она того заслуживает.

Считается, что невербальные реакции в меньшей степени контролируются сознанием и поэтому являются более надёжными индикаторами неискренности, чем содержание словесных высказываний. При этом наименее управляемы невербальные компоненты речи( темп, тональность, интонирование), если сравнивать их с мимикой и жестикуляцией, которые контролируются в большей степени. Экспериментально доказано, что легче распознать намеренный обман по телефону, чем в ситуации разговора с глазу на глаз, и это объясняется как раз тем, что в непосредственном контакте внимание уделяется преимущественно мимике, а в телефонном разговоре оно полностью сосредоточено на интонации и темповых характеристиках речи. 
Современные исследования общения гораздо больше внимания уделяют именно невербальной технике, что же касается собственно словесной составляющей общения, то ей больше везло в предшествующие эпохи, когда риторика была весьма уважаемым и почётным предметом. Правда, в последнее время наблюдается возрождение интереса к искусству красноречия, что позволяет надеяться на существенное обогащение наших знаний в этой области. А пока приходиться довольствоваться рецептами, известными со времен Цицерона и Квинтилиана, особенно в трактовке основных вопросов ораторского искусства, в технике составления речи, в признании ценности культуры в образовании оратора. От Цицерона воспринята, прежде всего, теория тройного деления стиля на простой, средний, высокий, которые оратор должен использовать уместно. Ведь цель речи подаётся в эмоциональном воздействии на слушателей, а также силе убеждения и доказательств.

Необходимо подчеркнуть особую важность согласования используемой лексики с невербальным контекстом. Например, торжественная речь неуместна в камерной обстановке, а её сопровождение невербальными знаками фамильярности производит комическое впечатление.

Разделение техники общения на технику говорения и технику слушания имеет направление в чём-то схожее с направлением дихотомии (раздвоенность, последовательное деление на две части, более связанные внутри)»невербальное-вербальное». И здесь современная наука делает акцент на технике слушания, опять таки потому, что в реальной жизни ей уделяется меньшее внимание. Действительно, нас учили говорить, но об учении слушанию до недавнего времени не было даже разговора.
Анализ коммуникативной практики показал, что далеко не всегда партнёры по общению выбирают лучшие средства организации слушания. Рассмотрим подробнее оба эти компонента общения.

Техника слушания. Процесс слушания можно разделить на две фазы: фазу поддержки и фазу комментирования. Обычно слушающий сопровождает речь говорящего разнообразными движениями( жестами: кивки, покачивание головой...). Это вокально-мимико-пантомимическое сопровождение выполняет роль поддержки и служит знаком слушания для говорящего и средством организации внимания для слушающего.

Фаза комментирования представлена более развёрнутыми репликами, которые произносятся, когда говорящий завершил какой-то фрагмент своей речи и ожидает развёрнутой реакции собеседника. Слушающий на время становится говорящим и комментирует сказанное ему. Здесь часто используются такие типы высказываний, как критика и выражение несогласия (Я думаю, вы не правы..), согласие и одобрение (Я согласен с Вашим мнением...), поучения, советы (Думаю, нужно...) и парафразпередача основной мысли собеседника своими словами. Особый вид реакций- переключения, которые могут быть тематическими (переводящими разговор на другой предмет) и стилистическими (например, обращение сказанного в шутку).

Техника слушания относительно независима от стратегии, однако эта независимость не абсолютна, и можно отметить преимущественное применение определённых педагогических техник при реализации разных установок на слушание. Есть слушание-для-говорения и есть слушаниедля-понимания. В первом случае собеседник выслушива- 
ется до тех пор, пока не созрела ответная реплика. При реализации данной установки характерно использование наводящих вопросов на фазе дифференциации (поддержки).На фазе комментирования превалируют оценочные суждения, интерпретация, советы и переключения.

При реализации установки слушания-для-понимания на фазе дифференциации чаще используются уточняющие вопросы, а на фазе комментирования- парафраз, который предваряет высказывание своей точки зрения. Парафраз наряду с уточняющими вопросами представляет собой средство для достижения взаимопонимания. Как уже отмечалось, парафраз это передача собственными словами высказанных мыслей и чувств собеседника. Использование собственных выводов и фраз свидетельствует об осмыслённости восприятия. И что особенно важно- неправильные интерпретации могут тут же быть исправлены партнёром.

Компетентное использование парафраза предполагает учёт наблюдения за информацией, если слушающий учитывает весть контекст диалогового общения.

Техника диалогового говорения включает в себя как вербальный, так и невербальный компоненты. По поводу последнего нужно сказать, что жестикуляция, как невербальный компонент общения, выполняет две функции. Во-первых, с её помощью у слушающего создаётся образное представление о предмете разговора, во-вторых, она используется для регуляции темпа речи (градации).

Относительно собственно вербальной техники надо отметить значительную роль выбора адекватного лексического слоя, что наряду с уместным использованием невербальной техники обеспечивает успешность установления и поддержания контакта в диалоге.
Стилю учебно-диалогового общения противопоказано излишне частое применение стилистических фигур (кроме учебных диалогов на уроках риторики, стилистики, русской литературы, на которых применение художественных средств русского литературного языка является признаком хорошего тона и чистой родной речи).Хорошим примером здесь может стать новый стиль научных публикаций, в которых нередко используются яркие образные сравнения и метафоры.

Ресурсы, которыми обладает индивид для организации эффектного общения в диалоговом обучении (дискуссии, дебаты, круглые столы...), не исчерпываются его коммуникативными навыками (техникой диалогового общения), которые определяются ( см.на рис 2):

- Оценивание информации, формулирование аргументов и объяснение сложных ситуаций и проблем.

- Определение и анализ различных точек зрения и мировоззрения

- Понимание различий в общении

- Оценивание действий, выводов и последствий.

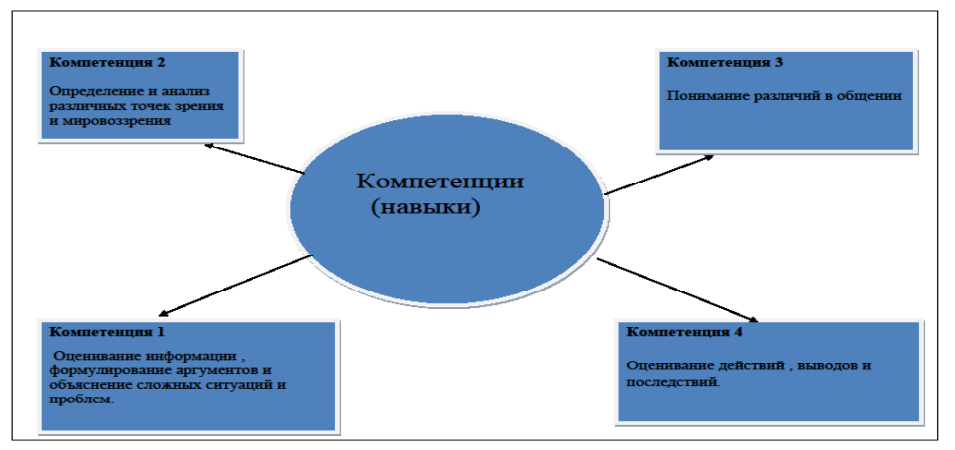

Рисунок 2 Компетенции,необходимые для организа- 
ции эффективного общения.

Можно сделать вывод: в настоящее время особенности социокультурной ситуации, усиление значимости не только выбора человеком своих поведенческих стратегий, но и его компетентности во взаимодействии с другими выводит задачу формирования коммуникативной компетентности в число приоритетных. Однако решение этой задачи сталкивается с неразработанностью коммуникативного подхода в образовании, учитывая формирование речевой компетентности в читательской грамотности $(\mathrm{CM}$. таблицу 2)

Таблица 2. Компетенции и содержательные области основного направления исследования по читательской грамотности.

\begin{tabular}{|l|l|}
\hline $\begin{array}{l}\text { Формирование } \\
\text { кечевой } \\
\text { в читатентности } \\
\text { грамотности }\end{array}$ & Компетенции \\
Содержательные области \\
Нахождение информации \\
Сплошной текст \\
Интерпретация текста \\
Несплошной текст \\
Рефлексия на содержание или на форму текста и \\
на его анализ,оценку \\
Смешанный текст \\
Составной текст
\end{tabular}

Вместе с тем анализ основной формы организации учебного процесса в массовой образовательной школеурока- показывает, что его содержание не включает формирование коммуникативной компетентности в качестве существенной и самостоятельной педагогической задачи. Это обуславливает дефицит взаимодействий, коммуникации педагога и учащихся и актуализирует (См.таблицу 2) необходимость реализации иного коммуникативного подхода; разработку разных моделей педагогической коммуникации для использования в организации урока, для оценки компетентностей в читательской грамотности, осуществление экспериментального исследования по использованию педагогических принципов реализации коммуникативного подхода .

Так же актуализируется необходимость раскрытия содержания коммуникативного подхода к организации образования, основанного на концептуальных идеях и положениях теории коммуникации (действия, рациональности, практики языкового понимания), которые будут осуществляться через когнитивную оценку, предназначенную для выявления способностей учащихся среднего звена критически изучать глобальные проблемы; распознавать внешние влияние на взгляды и мировоззрение, выявление развитости лингвистических и коммуникативных навыков, а это невозможно без развития познавательного процесса, посредством диалогового обучения. На основе этого, мы можем выделить основные принципы и компоненты педагогической диалоговой технологии, необходимой при формировании речевой компетентности, учитывающей процесс смыслообразования в формировании аргументированной базы ответа по проблемному вопросу (См. таблицу 3) 
Таблица 3. Основные принципы и компоненты педагогической диалоговой технологии

\begin{tabular}{|c|c|}
\hline Принципы: & Компоненты: \\
\hline $\begin{array}{l}\text { - проблемности и опти- } \\
\text { мальности; }\end{array}$ & $\begin{array}{l}\text { - коммуникатор (преподаватель, ко- } \\
\text { торый задаёт смысловую направлен- } \\
\text { ность диалога, ставит смысловую за- } \\
\text { дачу, создаёт смысловую установку и } \\
\text { является транслятором направления } \\
\text { смыслообразования учащегося); }\end{array}$ \\
\hline $\begin{array}{l}\text { - поэтапной подачи инфор- } \\
\text { мации; } \\
\text { - завершенности и неза- } \\
\text { вершённости диалога(на } \\
\text { осмысление); }\end{array}$ & $\begin{array}{l}\text { - мотив и цель смыслообразования } \\
\text { (то, что должно в диалоге вербализо- } \\
\text { вать личностный смысл); }\end{array}$ \\
\hline $\begin{array}{l}\text { - децентрации(или де- } \\
\text { централизации)(механизм } \\
\text { развития познавательного } \\
\text { процесса); }\end{array}$ & $\begin{array}{l}\text { - содержание (потенциальное поле } \\
\text { для образования смыслов); }\end{array}$ \\
\hline \multirow[t]{3}{*}{$\begin{array}{l}\text { - параллельного взаимодей- } \\
\text { ствия. }\end{array}$} & $\begin{array}{l}\text { - код коммуникации (устный или } \\
\text { письменный диалог, аргументирован- } \\
\text { ный или исследовательский); }\end{array}$ \\
\hline & $\begin{array}{l}\text { - } \text { рецепиент (т,е. ученик,у которо- } \\
\text { го учитываются мотивационно- } \\
\text { смысловые особенности речи); }\end{array}$ \\
\hline & $\begin{array}{l}\text { - результат (обратная связь, выявляю- } \\
\text { щая особенности смыслообразования } \\
\text { в процессе диалогового обучения, со- } \\
\text { относимого с уровнем учебного ре- } \\
\text { зультата). }\end{array}$ \\
\hline
\end{tabular}

Учитывая основные принципы и компоненты педагогической диалоговой технологии (вербальные и невербальные), мы выделяем такие виды вербальной технологии, как диалог: устный и письменный, аргументированный и исследовательский, так как именно эти виды формируют обратную связь, выявляющую особенности смыслообразования в процессе диалогового обучения, соотносимого с уровнем учебного результата

Среди диалоговых технологий мы выделяем: проблемно-поисковые диалоги, семинары-дискуссии, учебные дискуссии, эвристические ( вопросно-ответная методика доведения учащихся до самостоятельного познания) и кумулятивные ( используется с целью обмена знаниями, участники проявляют толерантность) беседы, анализ конкретных ситуаций.

Например,семинар-дискуссия (групповая дискуссия) образуется как процесс диалогического общения участников, в ходе которого, по нашему мнению, происходит формирование практического опыта совместного участия в обсуждении и разрешении теоретических и практических проблем. Мы предлагаем поэтапный алгоритм действий преподавателя- предметника и ученика(См.таблица 4)

Таблица 4. Поэтапный алгоритм действий преподавателя-предметника и ученика в ходе групповой дискуссии

\begin{tabular}{|c|c|}
\hline $\begin{array}{l}\text { Действия } \quad \text { преподавателя- } \\
\text { предметника: }\end{array}$ & Действия ученика: \\
\hline $\begin{array}{l}\text { - организовывает такую подго- } \\
\text { товительную работу, которая } \\
\text { обеспечит активное участие в } \\
\text { дискуссии каждого обучающе- } \\
\text { гося; }\end{array}$ & $\begin{array}{l}\text { - учится точно выражать свои мыс- } \\
\text { ли в сообщениях, докладах, высту- } \\
\text { плениях, активно отстаивать свою } \\
\text { точку зрения, аргументировано } \\
\text { возражать, опровергать ошибоч- } \\
\text { ную позицию соученика, имея до- } \\
\text { статочную доказательную базу по } \\
\text { теме; }\end{array}$ \\
\hline
\end{tabular}




\begin{tabular}{|l|l|}
\hline - определяет проблему и от- \\
$\begin{array}{l}\text { дельные подпроблемы, кото- } \\
\text { рые будут рассматриваться на } \\
\text { семинаре; }\end{array}$ & $\begin{array}{l}\text { ния собственной деятельности, что } \\
\text { его интеллектуальной и личност- } \\
\text { ной активности, включённости в } \\
\text { процесс учебного познания. }\end{array}$ \\
\hline - подбирает основную и до- & \\
$\begin{array}{l}\text { полнительную литературу для } \\
\text { докладчиков и выступающих; }\end{array}$ & \\
\hline - распределяет функции и фор- \\
$\begin{array}{l}\text { мы участия обучающихся в } \\
\text { коллективной работе; }\end{array}$ \\
\hline - готовит учеников к роли оп- \\
понента( тот, кто оппонирует- \\
возражает), логика; \\
\hline - руководит всей работой се- \\
минара; \\
\hline $\begin{array}{l}\text { - подводит итоги состоявшей- } \\
\text { ся дискуссии; }\end{array}$ \\
\hline $\begin{array}{l}\text { - задаёт вопросы, делает от- } \\
\text { дельные замечания, уточняет } \\
\text { основные положения доклада } \\
\text { ученика; }\end{array}$ \\
\hline $\begin{array}{l}\text { - фиксирует противоречия в } \\
\text { рассуждениях. }\end{array}$ \\
\hline
\end{tabular}

В ходе нашей исследовательской работы в тестировании, анкетировании, семинарах-дискуссиях по разным предметам, т.е. по общей теме нашего исследования принимали участие многие педагоги-предметники, члены администрации общеобразовательных школ. Итак, учитывая технические компоненты, применяемые в учебном диалоге при формировании речевой компетентности учащихся среднего звена общеобразовательных школ, можно сделать вывод: эффективность учебной дискуссии,учебного диалога как формирующей базы в речевой компетентности зависит от таких факторов, как: -подготовка слушания-для-говорения и слушаниядля-понимания по предложенной проблеме;

-информированность и компетентность учеников по обсуждаемой теме;

- семантическое однообразие (все термины, понятия должны быть одинаково поняты всеми учениками);

- корректность поведения участников;

- использование наводящих вопросов на фазе дифференциации ( поддержки);

- важность согласования используемой лексики с невербальным контекстом;

- умение преподавателя проводить дискуссию 
ГЛАВА 2.

Виды и типы обучающего диалога

Основное назначение диалоговой технологии обучения - научить выстраивать диалог на уроке на основе коммуникативной направленности и гуманистической парадигмы обучения. Знание основных типов и видов учебного диалога поможет успешному использованию данной технологии в учебной практике. Итак, на основе имеющихся данных, дадим точное определение терминам, напрямую связанным с диалоговым обучением.

Диалог - вид речевой коммуникации, состоящий в последовательном обмене репликами двух и более участвующих сторон.

Беседа - вид диалога, ориентированный на обмен информацией в ходе общения.

Разговор - разновидность беседы, использующаяся в межличностном общении.

Интервью (от англ, interview - опрос, собеседование) - разновидность беседы, при котором преимущественно одна из сторон задает вопросы с целью получения необходимой информации. Может реализовываться как в межличностном, так и в социально ориентированном общении.

Пресс-конференция - разновидность беседы в социально-ориентированном общении, заключающаяся в ответах на вопросы представителей средств массовой информации. В отличие от интервью имеет характер полилога.

Брифинг (от англ, brief - короткий, недолгий) краткая пресс- конференция, посвященная одному вопросу.
Обсуждение - вид диалога, представляющий собой разбор и оценку рассматриваемой проблемы в ходе общения.

Дебаты - обсуждение проблемных вопросов жизни и деятельности организации, региона, страны с конкретными предложениями, выводами по обсуждаемым проблемам.

Прения - индивидуальные регламентированные публичные выступления с изложением мнений, предложений по обсуждению темы доклада.

Спор - вид речевой коммуникации, характеризующийся столкновением точек зрения участвующих сторон.

Диспут (от лат. dispute - обсуждаю) - публичный спор с целью выработки однозначной позиции по какойлибо проблеме. Решение но результатам диспута принимается либо арбитром, либо путем общего голосования.

Дискуссия (от лат. dicussio - рассуждение) - вид спора, в рамках которого обсуждается проблема, с целью поиска оптимального (истина) или достижения взаимоприемлемого решения (компромисс).

Полемика (от лат. polemikos - враждебный) - вид спора, направленный на победу, утверждение одной точки зрения относительно предмета спора.

Нетрудно заметить, что эта классификация характеризуется нарастанием противоречий между участниками диалога от беседы к спору( См рис 3) 


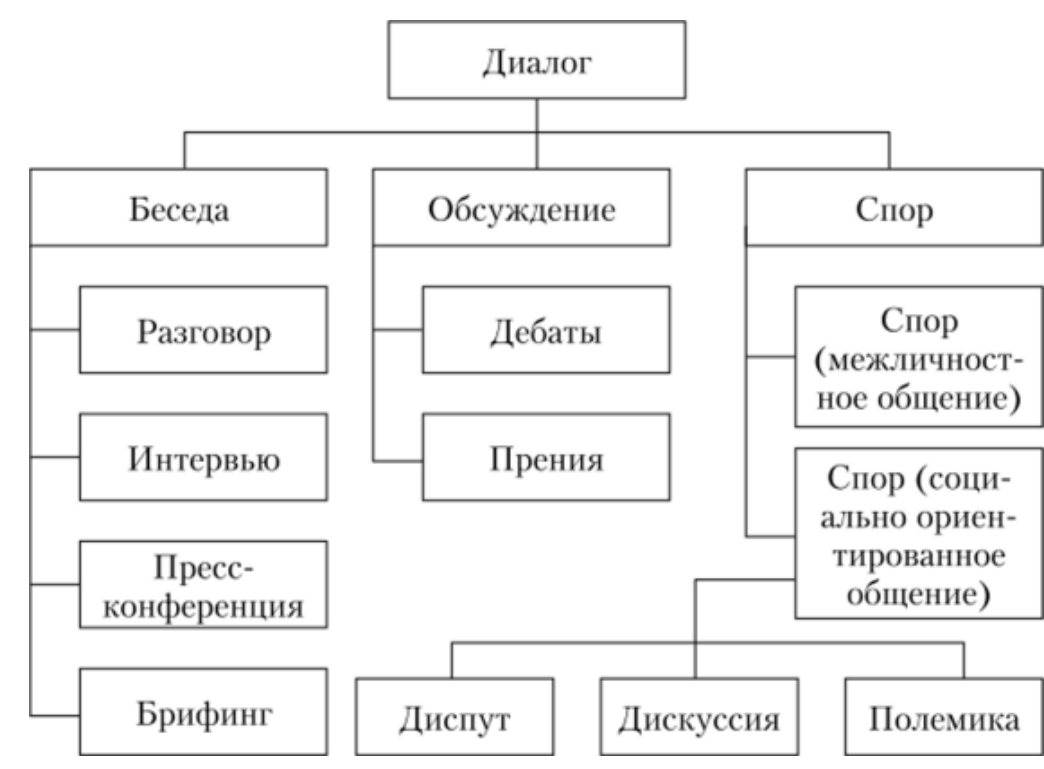

Рисунок 3.Типы диалога.

Отличительным признаком спора в межличностном общении является то, что его предмет не выходит за рамки частных интересов спорящих. Напротив, предмет спора в социально ориентированном общении затрагивает проблемы, вызывающие общественный интерес, характеризующиеся высокой социальной значимостью.

Заинтересованность в предмете взаимодействия и речевая активность участников достигает максимума в дискутивно-полемических разновидностях диалога. Рассмотрим их подробнее.

Диспут является древнейшей разновидностью спора, находившей широкое применение в научной, учебной и общественно-политической деятельности. Диспуты служили мерилом схоластической учености в Средние века - неудивительно, что в их проблематике преобладал 34 церковно-богословский аспект, как, например, в одном из первых известных диспутов по этой теме - Парижском диспуте между христианскими теологами и еврейскими раввинами по поводу антихристианской направленности Талмуда . По форме диспут представлял собой судебный процесс, закончившийся после победы христиан массовым сожжением иудейских книг.

Главный недостаток диспута заключается в наличии арбитра, чье мнение априорно предполагается самым квалифицированным. Это до определенной степени сковывает активность участников диспута, особенно если в качестве арбитра выступает лицо, наделенное административными полномочиями. С другой стороны, ангажированность арбитража предопределяет результаты диспута, снижая объективность выработанных в ходе его точек зрения; нетрудно, например, предположить, что результаты Парижского диспута могли бы быть другими, если бы в состав судей входили не только католики.

Таким образом, очевидно, что из видов спора целям и условиям использования в образовательном процессе в наибольшей степени отвечает дискуссия.

Стилистически жанр дискуссии относится к научному стилю речи, обслуживающему сферу научнопедагогической деятельности. Выработка умений и навыков владения этим стилем обучающимися, как уже отмечалось, является важнейшей педагогической задачей.

Дискуссия, в равной степени ориентированная на поиск истины или достижение компромисса, является диалектическим спором, практическим пособием по применению диалектического метода и средством развития критического мышления обучающихся. Ди а лекти ка объясняет природу развития мышления чисто риториче- 
ски, через триаду «тезис - антитезис - синтез». Наличие тезиса, т.е. применительно к научно-педагогической коммуникации какой-либо идеи, гипотезы, или научной теории, объективно предполагает возможность существования и антитезиса, в котором отражаются слабые стороны тезиса. Борьба между тезисом и антитезисом, выражающаяся во всестороннем анализе их сильных и слабых мест, продолжается до тех пор, пока не будет найдено какое-либо решение (синтез), в определенном отношении выходящее за рамки тезиса и антитезиса, но вобравшее их достоинства и минимизировавшее присущие им недостатки. Процесс научного синтеза, таким образом, тесно связан с дискуссией, в которой раскрываются и сравниваются различные аспекты тезиса и антитезиса. Для того чтобы дискуссия состоялась, необходимо прежде всего высказать тезис, суметь заметить противоречия в тезисе и сформулировать на их основе антитезис.

Бесконфликтная природа дискуссии наилучшим образом способствует воспитанию толерантности и развитию навыков общения. Бесконфликтность не означает отсутствие заинтересованности участников в утверждении своей точки зрения. Просто в дискуссии это подразумевает не стремление к победе в споре любой ценой, а получение интеллектуального удовлетворения от преобладания тезисов и аргументов своей позиции. Толерантность присуща дискуссии объективно, ибо условием вывода нового знания является понимание того, что было сделано до тебя, и стремление изложить свою точку зрения таким образом, чтобы она была понята и продолжена твоими последователями. Научное знание всегда относительно, и это является одним из главных оснований толерантности научной педагогической коммуникации.
Таблица 5.

Типы учебного диалога и их характеристика

\begin{tabular}{|l|l|}
\hline Типы диалога & Характеристика \\
\hline Мотивационный & $\begin{array}{l}\text { Отражает интерес его участников к теме, } \\
\text { диалогической форме общения }\end{array}$ \\
\hline Критический & $\begin{array}{l}\text { Характеризует критическое осмысление } \\
\text { содержания диалога, гипотетическое рас- } \\
\text { смотрение любых решений проблемы }\end{array}$ \\
\hline Конфликтный & $\begin{array}{l}\text { Отличается противоречивостью отноше- } \\
\text { ния личности к предмету проблемы }\end{array}$ \\
\hline Самопрезентирующий & $\begin{array}{l}\text { Демонстрация личностью выгодного для } \\
\text { неё имиджа }\end{array}$ \\
\hline Автономный & $\begin{array}{l}\text { Внутренний диалог, выражающий прове- } \\
\text { дение защитной реакции личности }\end{array}$ \\
\hline Рефлексивный & $\begin{array}{l}\text { Указывает на способность личности ве- } \\
\text { сти самоанализ }\end{array}$ \\
\hline Самореализующий & $\begin{array}{l}\text { Характеризуется моментом утверждения, } \\
\text { самораскрытия личности }\end{array}$ \\
\hline Смыслотворческий & $\begin{array}{l}\text { Характеризуется поиском личностью } \\
\text { ценностей }\end{array}$ \\
\hline Духовный & $\begin{array}{l}\text { Глубинное проникновение в содержание, } \\
\text { друг в друга }\end{array}$ \\
\hline
\end{tabular}

Анализируя типы и виды диалоговых технологий можно сделать вывод: организация уроков-диалогов связана также с определённым видом диалога:

1. Информационный, когда в процессе восприятия каждый партнёр получает новую информацию;

2. Интерпретационный, когда в ходе диалога происходит обмен мнениями, оценка известных обоим (многим) партнёрам фактов, их интерпретация. 


\section{ГЛАВА 3}

Методы и приемы обучения

монологической и диалогической речи.

Ведущей идеей в преподавании языковых дисциплин в современной общеобразовательной школе является коммуникативная цель, которая и определяет весь взаимосвязанный учебно-воспитательный процесс.

Одной из основных форм речевого общения, а это и есть основное направление нашего научного поиска, является диалогическая речь, в методике обучения которой и существуют противоречия.

В широком смысле слова диалог понимается как «акт непосредственного общения двух людей, протекающего в форме перемежающихся, ситуативно- обусловленных речевых действий (поступков); акт, возникающий по инициативе одного из говорящих в процессе его деятельности в тот момент, когда обстоятельства этой деятельности создают перед ним проблему, которую он может решить только путем вовлечения в эту деятельность другого лица (собеседника), в силу чего их общение развивается в направлении решения данной проблемы и угасает с ее разрешением» (Г.М.Кучинский).Таким образом, потребность вступления в диалогический контакт связан у учащихся с определенным побуждающим мотивом и порождаемой им речевой задачей, в реализации которых и проявляется инициативность говорящего; последняя может быть выражена в стремлении говорящего уведомить, информировать, получить информацию, уточнить, конкретизировать, доказать, обосновать, убедить и т.д. своего собеседника. То есть, воздействовать на своего партнера по общению с помощью речевых средств.
Несмотря на то, что диалогическая речь сложнее монологической с точки зрения разнообразия и количества используемых речевых образцов, тем не менее, с точки зрения последовательности в обучении устной речи все же предпочтение следует отдать этой формеобщения. Ведь именно через диалог отрабатываются и запоминаются отдельные речевые образцы, целые структуры, которые затем используются в монологической речи собеседников.

При обучении школьников диалогической речи решаются следующие основные задачи:

Во-первых, дать определение и раскрыть понятие диалога во всем его многообразии, особенно, в его естественной форме, чтобы учащиеся могли убедиться, что именно вопросно-ответная форма - лишь частный, хотя и самый распространенный случай диалогического общения. На различных примерах учителю следует показать ученикам, что речь лишь тогда будет живой, естественной и на самом деле диалогической, если в содержании реплик будут включаться приветствия, сообщения, приглашения, выражение различного рода чувств (удивления, благодарности, уверенности, сомнения, оценка фактов и т.п.).

Во-вторых, учителю следует обучить учащихся нужным репликам, затренировать их до уровня автоматизма при употреблении в конкретной ситуации.

И, наконец, в-третьих, учителю следует научить школьников обмениваться с этими репликами в соответствующих ситуациях, т.е. научить учащихся вести собственно диалог.

Учителю, по нашему мнению, необходимо научить учащихся, умению самостоятельно управлять диалоги- 
ческим общением, в процессе которого собеседники осуществляют регуляцию поведению партнера по общению. И все это следует делать не акцентируя внимания в плане языкового и содержательного оформления своих речевых высказываний. Отсутствие же коммуникативной общности между носителями разных языков, недостаточный лингвистический опыт усугубляют и затрудняют общение между ними особенно в случае уклонения собеседника от ответа на поставленный вопрос или нежелания говорить вообще. Нами замечено, что некоторые учащиеся хотят уклониться от естественной беседы не потому что не хотят использовать конкретные факты, а по причине слабого владения языковым материалом, диалоговой речью, в частности. Они, как показали наши наблюдения, боятся включиться в естественную беседу и, чтобы поскорее отделаться, ограничиваются ответамирепликами типа: - Да, Нет и т.п.

Задача учителя, по нашему мнению, должна сводиться к тому чтобы упреждать такую реакцию предполагаемых собеседников, формировать у учащихся коммуникативные способности управления общением, что обязательно включает в себя умения:

a) регулировать понимание воспринимаемого на слух речевого сообщения, а также;

б) активно управлять выдачей информации

Из этого, видимо, следует, что для формирования коммуникативной способностью управления диалогическим общением учащихся существует система подготовительных упражнений, которые делятся на два типа: речевые, которые непосредственно формируют умения и навыки самостоятельного высказывания, например, на иностранном языке, и тренировочные, типа структурных упражне- ний, которые помогают учащимся усвоить тот или иной аспект языка (произношение, лексику, грамматику).Наш опыт позволяет рекомендовать широкое использование разнообразных игр, которые готовят учащихся к коммуникации, обучают их быстрому реагированию и правильной реакции на стимулирующие вопросы. К таким играм, видимо, можно отнести:

Для учителя одной из самых трудных задач, по-нашему мнению, является развитие у учащихся умения самостоятельно развивать нить беседы, изменять и варьировать текстом составленного диалога.

В обучении диалогической речи немаловажное значение имеет групповой диалог. В классе, где всегда налицо группа учащихся, очень естественной может быть групповая беседа. По этой причине способность учащихся проводить естественный групповой диалог в классе можно считать одной из основных характеристик «конечного поведения», на достижение которого должно быть направлено обучение диалогической речи.

В естественном групповом диалоге на равных правах участвуют учитель и определенное количество учащихся (3-4 и более); каждый говорящий высказывается по нескольку раз; учащиеся обращаются к друг другу и к учителю непринужденно, без предварительной регламентации, в зависимости от содержания беседы.

Еще одним способом повышения качества и эффективности обучения диалогической речи можно считать и ролевую игру. Она позволяет учитывать возрастные особенности учащихся, их интересы; расширяет контекст деятельности; выступает как эффективное средство создания мотива иноязычному диалогическому общению; способствует реализации деятельностного 
подхода в обучении иностранному языку, когда в центре внимания находится ученик со своими интересами и потребностями. Ситуации общения, моделируемые в ролевой игре, позволяют приблизить речевую деятельность на уроке к реальной коммуникации, дают возможность использовать язык как средство общения. Ролевая игра способствует реализации общего методического принципа коммуникативной направленности обучения иностранному языку.

Особое значение ролевая игра приобретает в обучении иноязычной диалогической речи именно на среднем этапе обучения, то есть у школьников подросткового возраста. Известно, что учащихся переходного возраста характеризует «чувство взрослости»: подростки стремятся быть похожими на взрослых, представлять себя взрослыми и совершать соответствующие речевые поступки. Ролевая игра как раз и обеспечивает общение на взрослом уровне, позволяет детям проявлять инициативу и самостоятельность, реализует их стремление к самоутверждению. Ее применение на данном этапе способствует усилению мотивации к изучению иностранного языка и тем самым поддержанию ее на старшей ступени обучения.

Разумеется, на средней ступени обучения, невозможно научить учащихся всем особенностям диалогической речи. Однако беседа учащихся по возможности должна быть более жизненной и сохранять основные, присущие ей качества. Так, учащиеся должны уметь правильно начать беседу, употребив одно из наиболее употребительных приветствий. Они должны уметь задать вопрос и ответить на него как в краткой форме, так и в виде небольшого монологического высказывания. Ученики на данном этапе обучения должны уметь поддержать разговор, развить мысль собеседника и довести диалог до его логического конца.

Различные приемы формирования диалогической речи имеют положительное значение в плане подготовки учащихся умению вести свободную беседу по пройденной теме в пределах программного материала. В итоге значительно повышается эффективность урока немецкого языка, где все большее количество учащихся вовлекается в активную речевую деятельность на уроке и вне его, способствует развитию инициативности обучаемых, а также развитию и совершенствованию их умений. Как показывает практика, данные методы способствуют положительным изменениям в речи учащихся как в качественном отношении (разнообразие диалогических единиц, инициативность речевых партнеров, эмоциональность высказывания), так и в количественном (правильность речи, объем высказывания, темп речи), что свидетельствует об эффективности предлагаемой методики. Но самое главное, что надо учитывать при организации диалогического общения - это создание положительного эмоционального настроя к выполняемой учащимися деятельности, учитывая сематические формы речи в диалоговом обучении. Формы, обуславливающие взаимообщение индивидов: активные и пассивные, диалогические и монологические. 

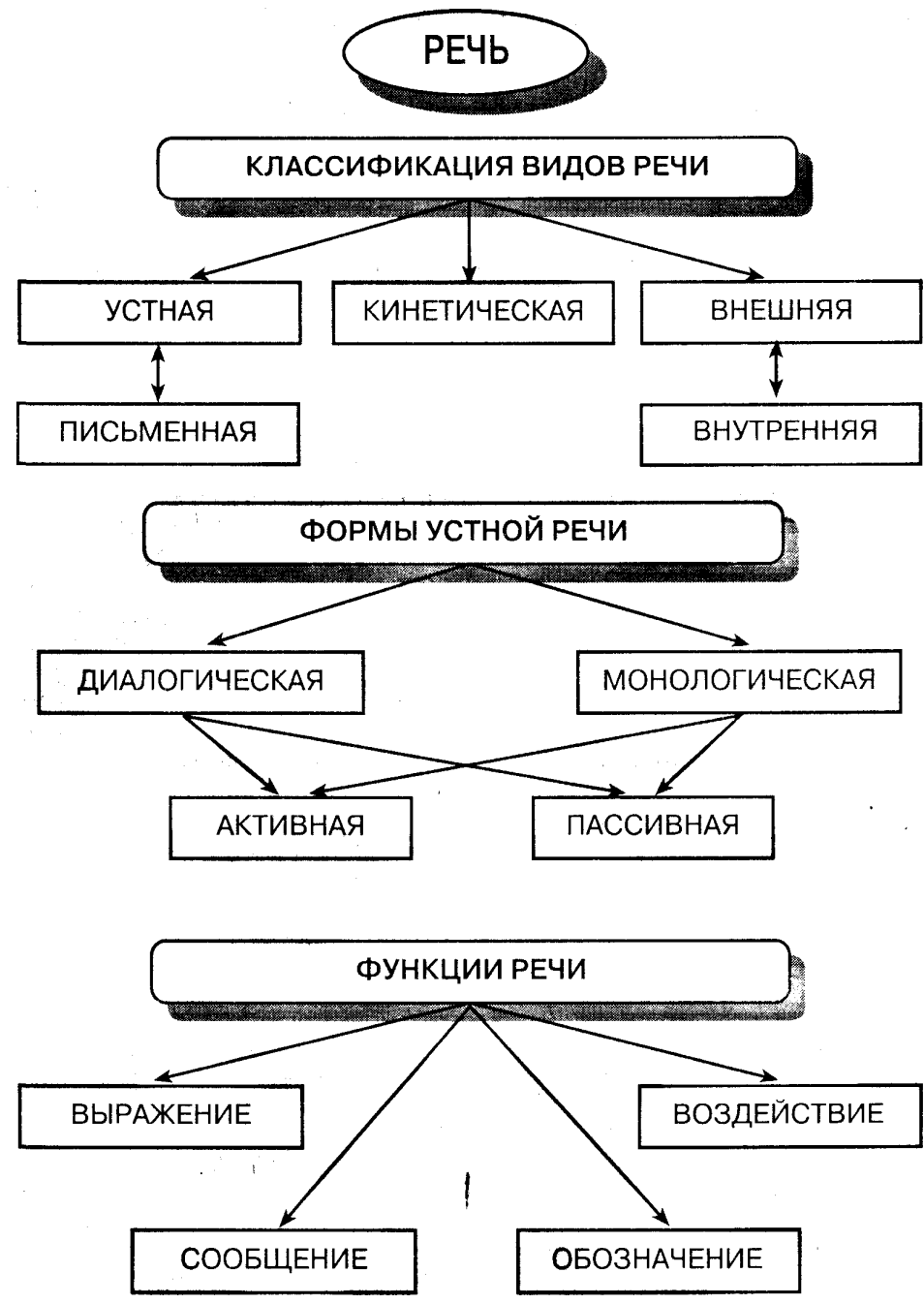

Рисунок 4. Классификация видов речи.

\section{Монологическая речь.}

Монологическая речь представляет собой связное непрерывное изложение мыслей одним лицом, обращенное к одному или нескольким лицам. Цель этой направленности, обращенности - достигнуть необходимого воздействия на слушателей.

В отличие от диалогической речи, которая является в основном ситуативной, монологическая речь преимущественно контекстна. Иногда и она может быть ситуативной, например, спонтанное высказывание - развернутые реплики в диалоге, которые можно рассматривать как краткие монологические высказывания - «микромонологи в диалоге». Монологическая речь в некоторых случаях может быть наглядно-ситуативной, если она сопровождается зрительным рядом в кинофильме, в телевизионных передачах.

Важной психологической особенностью монологического высказывания в отличие от диалогической речи является его непрерывность, которая позволяет говорящему связно и полно высказывать свои мысли.

В силу контекстности монологической речи к ней предъявляются особые требования: она должна быть понятной «из самой себя», т.е. без помощи неязыковых средств, которые часто играют большую роль в ситуативной диалогической речи. Последовательность и логичность, полнота и связность изложения мысли являются важнейшими качествами монологической речи, вытекающими из ее контекстной природы.

Как известно, монологическая речь имеет следующие коммуникативные функции:

-информативную - сообщение новой информации в 
виде знаний о предметах и явлениях окружающей действительности, описание событий, действий и состояния;

-воздейственную - убеждение кого-либо в правильности тех или иных мыслей, взглядов, убеждений, действий; побуждение к действию или предотвращению действия;

-эмоционально-оценочную.

Для каждой из перечисленных выше функций монологической речи характерны свои языковые средства выражения и особые психологические стимулы. Сравним: нейтральное в эмоциональном отношении сообщение информации с одной стороны, и стремление убедить слушателя с помощью эмоционально - выразительных средств языка - с другой.

В психологической литературе отмечается, что по сравнению с диалогической речью монологическая речь является более сложной и трудной. Она требует от говорящего умения связно и последовательно излагать свои мысли, выражать их в ясной и отчетливой форме. При овладении монологической речью на иностранном языке эти трудности значительно осложняются в связи с тем, что обучаемые не владеют свободно языковыми средствами, которые необходимы говорящему для выражения мысли.

Методика обучения монологической речи

Целью обучения монологической речи, как уже отмечалось, является формирование умений монологической речи, под которыми понимаются умения коммуникативномотированно, логически последовательно и связно, достаточно полно и правильно в языковом отношении излагать свои мысли в устной форме.

Учащиеся должны уметь:
- рассказывать о себе, своей семье, друзьях, своих интересах и планах на будущее, сообщать краткие сведения о своем городе / селе, о своей стране и стране изучаемого языка;

- делать краткие сообщения, описывать события / явления (в рамках пройденных тем), передавать основное содержание, основную мысль прочитанного или услышанного, выражать свое отношение к прочитанному / услышанному, давать краткую характеристику персонажей;

- использовать перифраз, синонимические средства в процессе устного общения.

Для формирования умений монологической речи следует четко спланировать и методически правильно организовать процесс обучения этому виду речевой деятельности.

Выделяют 2 пути обучения монологической речи - дедуктивный и индуктивный.

При обучении монологической речи по индуктивному пути предлагаются следующие этапы работы.

1. Подготовительный этап. Цель этапа - формирование лексико-грамматических навыков на уровне фразы.

На данном этапе возможно использование следующих упражнений:

Система условно-речевых упражнений:

- Имитативные упражнения: учитель дает образец каждого речевого действия, выступающего для ученика в качестве ориентира, и затем с помощью побудительной реплики побуждает ученика к аналогичному действию.

- Упражнения на подстановку грамматических структур: с помощью реплик (Учитель осуществляет пошаговое управление действиями учащихся.) 
- Трансформация. ( Видоизменение форм.К примеру «Полезно есть овощи.» «Я знаю, но я не ем овощи.»)

2. Предречевой (сверхфразовый) уровень микромонолога. Цель этапа - формирование навыков монологической речи на уровне сверхфразового единства (соединить реплики между собой, т.е. логично простроить высказывания).

Логико-синтаксическая схема: даются начала фраз, которые обеспечивают целостность высказывания, его логичность и синтаксическую связанность.

3. Речевой этап, уровень развернутого монологического высказывания. Цель-развитие умения монологической речи на основе темы, ситуации.

Собственно-речевые упражнения: сообщи, расскажи, убеди.

При обучении монологической речи по дедуктивному пути предлагаются следующие этапы работы над текстом:

1. Предтекстовый этап. Цель этапа - побудить к прогнозированию содержания текста; обеспечить осознание коммуникативной задачи, нацеливающей на то, как читать; предоставить возможность снять часть трудностей.

2. Текстовый этап. Цель этапа - нацелить на чтение текста с разной степенью проникновения в его содержание и смысл, на информационную переработку текста в процессе чтения с целью его лучшего понимания.

Учитель предлагает задание: а теперь прочитайте текст и скажите, о чем идет речь. (Таким образом, происходит проверка правильности сделанных прогнозов и уточнение их.)

3. Проверка понимания текста. Цель этапа - осуществить контроль полноты и адекватности понимания со- держания и смысла текста в зависимости от вида чтения. На этом этапе можно провести тест на множественный выбор для проверки понимания основной информации или деталей.

4. Информационная переработка текста с целью ее присвоения. Цель - повторно вернуться к тексту и информационно его переработать, присвоить информацию и языковые средства, необходимые для порождения устноречевого высказывания.

Упражнения: - выбор заголовка из данных вариантов, -придумывание заголовка, нахождение основных мыслей, - деление текста на смысловые отрезки, ответы на вопросы, позволяющие выделить основную информацию, детали, -составление развернутого плана текста, -подбор к пунктам плана предложений из текста, уточнящего его.

5. Порождение устноречевого высказывания. Цель этапа - обеспечить осознание коммуникативной задачи, нацеливающей на порождение собственно устноречевого высказывания на основе текста или в связи с текстом.

Упражнения: - выскажи свое мнение (понравился/ не понравился текст) сформулируй главную мысль текста, кратко изложи основные факты содержания текста, перескажи текст и придумай продолжение истории, составь объявление по данной теме и др.

B7- 9классах могут использоваться опоры - наглядность, ситуация, текст, уровень владения монологической речью должен быть высоким.

Так, монологические комментарии к картинкам приобретают подлинно коммуникативный характер: монологические высказывания по поводу изображенного на картинке, возможно элементарное обсуждение художественных и идейных достоинств картинки (если она яв- 
ляется репродукцией оригинального художественного произведения).

В старших классах тексты, содержащие интересную информацию, могут послужить материалом для обсуждения. Учащиеся старших классов уже располагают определенным индивидуально-речевым опытом, который позволяет им творчески использовать этот источник информации в монологической речи. При этом возможны различные трансформации исходного текста: частичная трансформация языковых средств (пересказ близко к тексту), частичная трансформация содержания (пересказ своими словами), комментарий, интерпретация текста при его обсуждении.

Работа с (прочитанным) текстом приобретает на этом этапе особое значение. Проводятся такие творческие упражнения, как связное высказывание об основных идеях отрывка (текста), поступках героев, изложение (возможно, критическое) содержания отдельных эпизодов и сцен. Эти упражнения способствуют развитию творческой монологической речи.

Одну из важных опор для монологических высказываний представляет собой тема, потому что обучение устной иностранной речи и языку в школе в конечном итоге строится по тематическому принципу.

Отмечая тематическую связность монологической речи учащихся как одну из ее особенностей, следует указать на нерациональность заучивания наизусть готовых текстов по темам как основы для развития тематически связной монологической речи. Такая речь часто оказывается механически заученной, лишенной элементов творчества. Самое трудное при обучении иноязычной речи, в том числе монологической речи, добиваться того, чтобы ученик научился экономно и творчески использовать активный языковой материал и умел выражать свои мысли правильно и просто (но не примитивно). Этому необходимо систематически обучать.

Таким образом, можно выделить следующие основные положения:

1. Монологическая речь - одна из форм устной речи, лингвистические и психологические особенности которой необходимо учитывать при обучении.

2. Основными коммуникативными функциями речи являются информативная, воздейственная, эмоциональнооценочная.

3. Основные свойства монологических речевых умений: логичность и связность изложения мыслей; коммуникативно-мотивированное и творческое пользование языковыми средствами, правильность речи на коммуникативно-достаточном уровне.

4. Упражнения в развитии монологических умений можно классифицировать по видам опор (по наглядности, по речевой ситуации, по теме, по мотивам темы, по прочитанному или воспринятому на слух тексту) и по объему высказывания (отдельные предложения, краткие связные высказывания, полные тематические связные высказывания). 


\section{Диалогическая речь.}

Диалогическая речь своеобразнее, сложнее монологической, и с точки напряженности внимания, и с точки зрения разнообразия и качества используемых речевых образцов, тем не менее, с точки зрения последовательности в обучении устной речи все же отдается предпочтение отдается диалогической речи. Эту точку зрения мы пытались провести в наших прежних публикациях (см. список литературы), а также «За чистоту речи», - Уральск, 2021. Мы настаиваем и это согласуется с мнениями других авторов, что именно через диалог отрабатываются и запоминаются отдельные речевые образцы, целые структуры, которые используются затем в монологической речи. Уже на начальных этапах учащиеся могут, а учитель должен им помочь приобрести умение пользоваться изучаемым языком для общения.

Разработка и внедрение в образовательный процесс новых форм и технологий обучения позволяет по-новому взглянуть на основной инструмент и одновременно «вечную» проблему педагогики - учебный диалог, который является «механизмом» перехода объективированного содержания образования в личностные смыслы учащегося.Диалогическое общение на уроке - это не только способ совершенствования образовательного процесса, но и особая форма субъект-субъектного взаимодействия, при котором, как считает С. Н. Батракова, происходит «встреча позиций по сущностным проблемам. Проявляются, уточняются, дополняются, обогащаются и преобразуются взгляды, интересы и мотивы, которые в той или иной степени определяют личность» .Белякова Е. Г под дидактическим взаимодействием понимает систему взаимно обусловленных действий субъектов образовательного процесса: поведение каждого из участников выступает одновременно и стимулом, и реакцией на поведение остальных .

Диалог «учитель - ученик» обычно называют парным, но в реальной практике учебного процесса значительно чаще происходит диалог между учителем и классом. Такой «полилог», или множественный диалог, включающий нескольких коммуникантов, имеет комплексную структуру. Еще более сложную форму имеет диалог между группами учащихся, когда учитель выступает в роли своеобразного арбитра.

Практика показала, что любой учебный диалог «управляется» учителем. Это управление, по нашему мнению, должно проявляться в мягкой, косвенной, опосредованной форме - в психологической и педагогической поддержке учащихся, наводящими вопросами, остановках на пути постижения детьми «смысловых единиц жизни». Равноправными партнерами в процессе диалога учитель и учащиеся не являются, поскольку педагог, в отличие от учеников, обладает профессиональной компетентностью, однако педагогическая мудрость состоит в том, чтобы учащиеся тем не менее считали себя равноправными участниками диалогического процесса. Речь идет о равенстве как взаимном уважении, соблюдении достоинства сторон. Диалог в учебном процессе предстает в некоторой условной, имитационной форме: имея преимущество и, как правило, зная заранее ответ, учитель выстраивает педагогическую стратегию, иногда намеренно приводя поступающую от него информацию в несоответствие с той, которой владеют ученики. Учитель сознательно стремится к тому, чтобы получить от учащихся «обратную вол- 
ну» и тем самым придать учебному процессу характер «пульсации самодвижения». Ради заинтересованного и деятельного участия школьников в поисках истины, для формирования их личностного отношения к рассматриваемому содержанию, которое выступает объектом диалога, в действие приводятся различные механизмы познавательной деятельности учащихся.

Учебный материал как носитель содержания - та «личностная территория», на которой в диалоге «встречаются» учитель и учащиеся и где разворачиваются события смыслового порядка. Рассматривая диалог как дидактический механизм психологического процесса смыслообразования учащихся, важно обратить внимание на отбор содержания. Для учебного диалога необходим особый, объективно ценный материал, значимый в глазах учащихся. Таким материалом для нас являются организующие идеи, проблемные и неоднозначные вопросы учебного материала (Что принес период «оттепели» истории России?; Правильно ли поступила учительница Лидия Михайловна в рассказе В. Распутина «Уроки французского»?). Как правило, такое содержание исключает упрощенчество в учебном процессе, предполагает серьезное к нему отношение, обеспечивая таким образом предпосылки для построения диалога. Через небезразличное отношение учащихся к содержанию, к тем жизненным реалиям, которые за ним скрываются, весь диалог приобретает смысл, личностно воспринимается как значимый для них процесс ( См.рис 5).

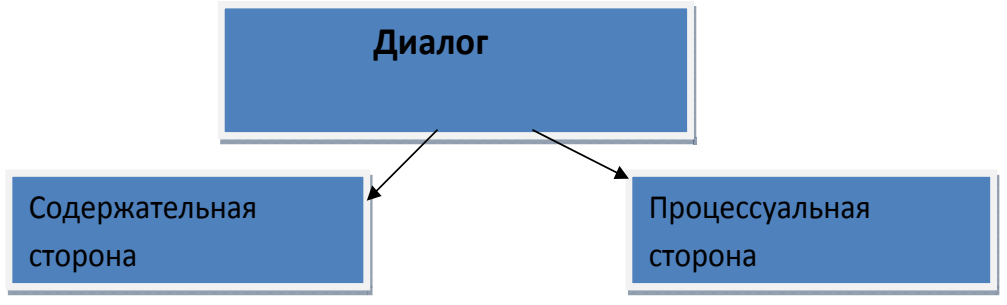

Рисунок 5. Стороны учебного диалога

Содержательная сторона диалога - лишь часть рассматриваемой проблемы. Другая часть - процессуальная - состоит в том, что диалог -беседа, но беседа особого рода. Вопрос учителя либо поступающая от него информация могут порождать со стороны учащихся неоднозначность ответов, разнообразие мнений, предположений. Для школьников учебный процесс, таким образом, значим не столько ответами, сколько вопросами, которые, в свою очередь, могут породить новые вопросы со стороны учителя, и так до бесконечности. Множественность вопросов и ответов, кооперированная деятельность учащихся - все должно быть подчинено поиску объективных или субъективных истин. На содержание вопроса учащихся, как правило, влияет их личный жизненный опыт. Значительное количество информации школьники приобретают за пределами школы, из таких источников, как телевидение, кино, Интернет, научно-популярная литература. Существенными свойствами личного опыта учащихся являются неупорядоченность впечатлений, противоречивость воспринятой информации, неоднозначность точек зрения. Современный ребенок, бессистемно и дискретно информированный по самым разным вопросам, зачастую испытывает определенные сложно- 
сти из-за наличия противоречий между той информацией, которую он получает вне стен школы, и программным материалом. Нередко именно это побуждает его обращаться с вопросами к учителю.Культурный опыт ученика по своей значимости неодинаков. Как известно, содержание сознания человека делится на актуально сознаваемое и контролируемое. Соответственно этому приобретаемый учеником опыт в общей структуре освоенного им содержания распределяется по-разному. Одна часть опыта занимает более актуальные, другая - менее актуальные зоны сознания. Актуальный опыт, т. е. то, к чему учащийся небезразличен, должен стать основой и предпосылкой формирования смысловых образований в качестве дидактического фактора .

В обучающем диалоге смыслообразующие возможности проявляются наиболее рельефно. Диалог предполагает обращение учителя прежде всего к актуально значимому для учащихся опыту, с тем чтобы задействовать скрытую силу личностного смысла, смысловых установок, смысловых конструктов и т. д.

\section{ГЛАВА 4. Собственный педагогический опыт формирования диалектических умений учащихся на занятиях в школе.}

Диалогическая речь представляет собой яркое проявление коммуникативной функции языка. Участвовать в диалоге иногда бывает труднее, чем строить монологическое высказывание. Обдумывание своих реплик, вопросов происходит одновременно с восприятием чужой речи. Участие в диалоге требует сложных умений (См.рис 6)

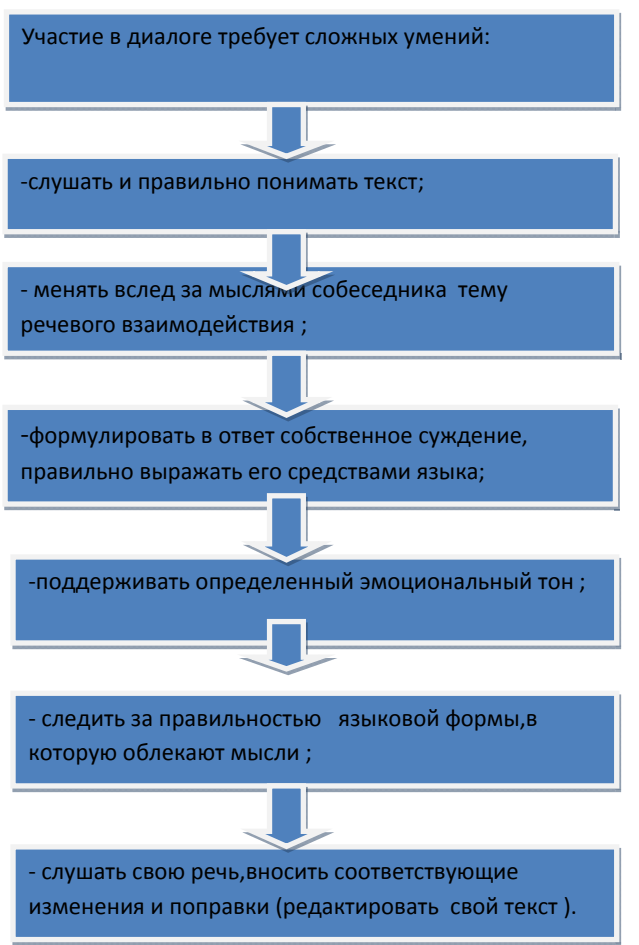

Рисунок 6. Диалоговые компетенции (умения) 
Строевой единицей диалогической речи является диалогическое единство: сочетание двух или более взаимосвязанных реплик. Чтобы овладеть этой формой речи, нужно усваивать различные типы диалогических единств.

Овладение диалогическим единством того или иного типа будет идти через группу упражнений. Вначале обучающиеся знакомятся с образцом диалогического единства. Затем они учатся строить отдельные реплики. Наконец, упражняются в составлении целого диалога. Для упражнений в диалоге предлагаются ситуативные задания. Обучение происходит поэтапно.

Первый этап. Вопросно-ответная форма речи. Вопросно-ответная форма диалогического общения наиболее типична, и она используется как для решения познавательных, так и социально-коммуникативных задач. С одной стороны, коммуникативная задача вопроса заключается в получении новой информации или уточнении уже имеющихся сведений. С другой, именно вопрос чаще всего становится инициативной диалогической репликой. Он служит не только носителем информации, но и побуждает к ответному высказыванию. Умение и желание обучающегося задавать вопросы свидетельствуют о его активном восприятии и сознательном усвоении знаний. Чтобы спросить о чем-то, дети должны уметь выделить главное, осознать проблему и верно сформулировать ее. Таким образом, обучение умению отвечать на вопросы помогает развитию умения лексико-синтаксически оформлять результаты мыслительной деятельности. Для формирования вопросно-ответной формы речи используются различные виды беседы, игры. Сначала необходимо развивать у детей умение отвечать на вопросы и задавать их. Особое внимание уделять формированию уме- ния слушать и слышать собеседника, используя для этого различные игры.

1. Стратегия «Распространение предложений»: По сюжетной картинке первый обучающийся составляет простое нераспространенное предложение, каждый следующий добавляет к нему по слову.

2.Стратегия «Снежный ком»: Требуется составить рассказ на заданную тему по кругу. Каждый участник начинает свою фразу с повторения конца фразы предыдущего.

3.Стратегия ."Merry-Go -Round" "Карусель”: обучающиеся встают в 2 круга, задают друг другу вопросы по теме «Знакомство», затем заполняют общую таблицу с информацией. Следующим заданием может быть рассказ о друге.

4. Стратегия. "Ask andanswer" "Вопрос-ответ": обучающимся предлагается поиграть в игру "Вопрос-ответ". Учитель произносит утвердительное предложение и кидает мячик любому из обучающихся, обучающиеся должны задать специальные, альтернативные или общие вопросы.

Второй этап. Обобщение. Здесь на первый план выходит общение учащихся друг с другом. Для этого создаются различные коммуникативные ситуации, игры для общения. 
Игра “Интервью”: обучающимся предлагается поиграть в игру “Интервью”, но учитель предупреждает о том, что они могут задавать только разделительные вопросы. Один из обучающихся выходит к доске и отвечает на разделительные вопросы остальных обучающихся

Третий этап. Применение полученных и усвоенных навыков. На этом этапе используются диалоги, сюжетноролевые игры, диалоги с незнакомыми взрослыми и сверстниками. Сюжетно-ролевая игра отвечает потребности детей воплотить в жизнь собственные замыслы, выразить свои переживания. В процессе игры они переходят от реализации хорошо усвоенных сюжетов к самостоятельному построению новых.

Стратегия . “Новый ученик”: Учитель сообщает детям, что у них в классе появился новый обучающийся, и детям необходимо познакомится с ним, задать необходимые вопросы. "Новый” обучающийся выходит к доске, а остальные обучающиеся задают ему различные вопросы. Тему вопросов лучше задать, причем в два приема:

1. Имя, возраст, откуда приехал, семья. (Интервью.) Затем ближе к изучаемому материалу или теме урока:

2. В каком классе, любимый предмет, т.е. необходимо сформировать у детей определенные логические схемы ведения беседы.

$$
\text { Диалог } \rightarrow \text { Схема диалога }
$$

Прямая речь $\rightarrow$ Схема прямой речи.
Можно выделить несколько типов диалога, которые позволяют особым образом предъявлять ценности, создают основу для глубокого их переосмысления и реализуют иноязычный акт коммуникации. Одним из таких типов является духовный диалог. Для него свойственны глубокое понимание сущности проблемы, высокий уровень культуры диалогического взаимодействия. Например, обучающимся предлагается познакомиться с писателем и его книгой, а затем на основе предложенной информации они должны ответить на следующие вопросы:

1. Вы еще не прочли эту книгу, но вы уже можете коечто о ней сказать.

2. Что вы ожидаете от этой книги?

3. Выскажите, пожалуйста, ваши предположения.

Возможен смыслотворческий диалог, активно включающий участников в поиск новых смыслов, в процесс определения системы индивидуальных ценностных ориентации.

1. Посмотрите на картину и скажите, какой теме она посвящена. (любовь)

2. Что вы ожидаете от серьезной любви?

3. Нравятся ли вам герои картины?

4. Что приходит вам на ум, когда вы смотрите на эту картину? Выскажите ваши предположения, чем может закончиться эта любовная история. Как по-вашему, подходит ли картине название? Как бы вы ее назвали? Обсудите содержание данной картины с вашим другом. Разыграйте диалог.

Имеет большое значение рефлексивный диалог, позволяющий оценить собственный потенциал. Например: Составьте диалог к следующим ситуациям по теме «Проблема «маленького человека «в произведениях классиков 
«.(- Кто такие «футлярные люди», что они представляют собой ?- «Счастливые и несчастливые герои «маленькой трилогии.»

Для участников субъектно-смыслового общения может стать привлекательным самореализующий диалог, назначение которого, прежде всего, в утверждении личности, полноценной самопрезентации и самовыражении.

1. Чем бы вы занялись во время поездки в незнакомую страну в качестве туриста?

2. Что бы вы делали, если бы оказались в чужой стране на долгое время или навсегда?

3. Спросите ваших одноклассников, что бы они делали, если бы очутились в США . Разыграйте диалог.

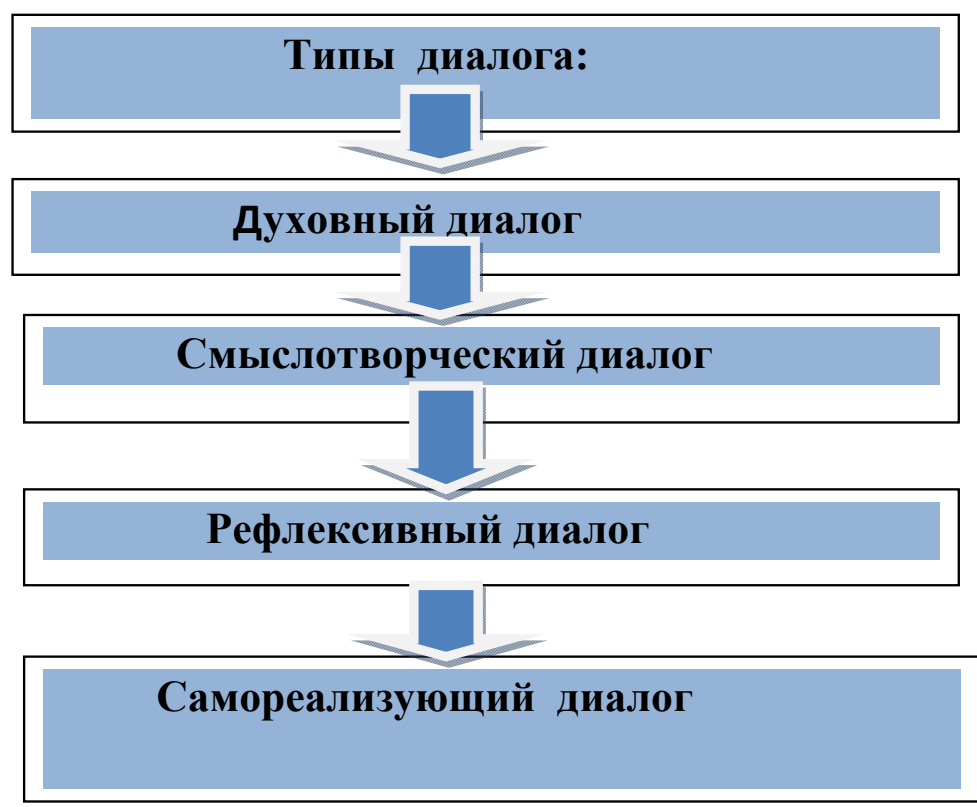

Рисунок 7. Типы диалога.

\section{Педагогический диалог как особая форма коммуникации}

Педагогический диалог как особая форма коммуникации стратегичен по своей сути, поскольку педагог, выстраивая взаимодействие с классом, осуществляет свое коммуникативное намерение, производит выбор содержания учебного материала, а также отбор лексических средств, необходимых для реализации диалога. В общем виде педагогическая коммуникативная стратегия при проектировании диалогического обучения включает в себя:

1) выбор глобального речевого намерения педагога дидактической интенции (например, намерений выявить общий пресуппозиционный фонд (наличие у говорящих совокупности знаний, представлений, взглядов, необходимых для понимания текста), скоординировать совместную деятельность, убедить, скорректировать процесс понимания);

2) отбор лексических средств, адекватных условиям педагогического взаимодействия на уроке;

3) определение объема содержания учебного материала, который передается посредством реализации избранной стратегии;

4) установление порядка речевых тактик (конкретных вопросов, реплик), позволяющих эффективно реализовать стратегию;

5) приведение в соответствие коммуникативной структуры развернутого высказывания определенному стилю (научному, разговорному).

Использование различных диалоговых стратегий в определенной последовательности позволяет более эф- 
фективно организовать процесс смыслообразования.

Диалоговые стратегии можно соотнести с основными этапами изучения новой темы в рамках классической структуры урока. Однако необходимо отметить, что, с одной стороны, этапы изучения новой темы и этапы смыслоориентированного урока могут не совпадать - эта корреляция условная и допускает стихийные изменения в связи с контекстом урока или с непредсказуемыми факторами, которые могут возникнуть в ходе урока и повлечь за собой изменения в структуре диалога. С другой стороны, учитель вправе целенаправленно распределить нижеописанные этапы изучения новой темы на несколько уроков, если стандартный урок продолжительностью сорок - сорок пять минут не позволяет реализовать все этапы и типы учебного диалога в полной мере.

Педагогические стратегии проявляются в тактиках совокупности речевых действий, приемов, которые соответствуют отдельным этапам реализации диалоговой стратегии (См. рис 8).

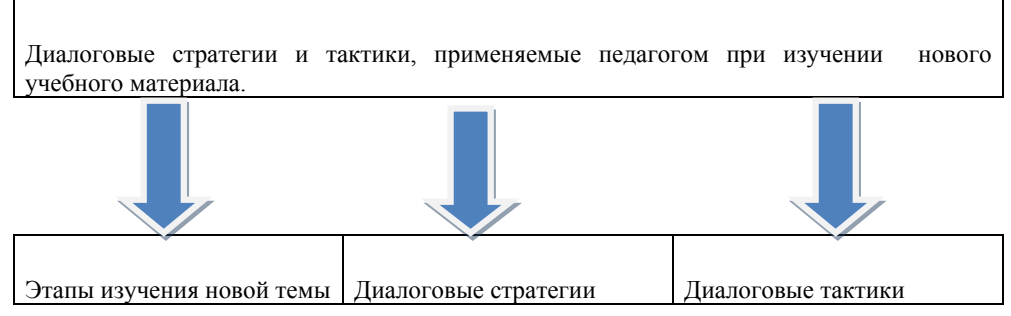

Рисунок 8. Диалоговые стратегии и тактики

Освоение нового знания Информационно- смысловая Первичное изучение (восприятие) учебного материала; по- гружение в учебный материал с привлечением культурного опыта субъектов; «вживание» в учебный материал, экстраполяция пройденного на свой личный опыт. Применение знания Оценочная Выявление ошибочных толкований; утверждение правильных толкований; эмотивная оценка. Коррекция процесса усвоения смыслов Регулятивноконтролирующая Этап «целеполагание» предполагает осознание учеником как субъектом образовательного процесса цели и значимости изучения данной темы. Этот этап может быть соотнесен с этапом «Организационный момент» в классической структуре урока . Как правило, он не занимает много времени, но при этом имеет важное значение: педагогу необходимо учитывать позицию учащегося, который оценивает происходящее, основываясь на своих интересах и предпочтениях. Учителю важно «встроить» эти интересы и предпочтения в смысловую канву урока. На данном этапе целесообразно использовать экспрессивно-риторическую стратегию, которая может быть реализована в виде следующих диалоговых тактик: формирование эмоционального настроя, самопрезентация, установление контакта. Диалоговая тактика «формирование эмоционального настроя» интенционально обусловлена намерением субъектов дидактического взаимодействия «существовать» в комфортной образовательной («рабочей») среде, при необходимости выразить свое эмоциональное отношение к происходящему и имеет целью создание необходимого коммуникативного контекста. В процессе общения на уроке очень важен эмоциональный фон коммуникации, адекватный уровень взаимоотношений, обмен эмоциями и т. п. Данная тактика реализуется в эмпатийно-личностном типе учебного диалога, используются такие типы реплик, как пожелание, приглашение к совместной деятельности, комплимент. 
Тактика «самопрезентация» имеет целью формирование определенного имиджа. Она проявляется в поведении человека, манере говорить, стиле одежды, т. е. во всем его образе.

В дидактическом аспекте для учителя очень важно умение установить контакт с обучаемым, это залог успешного коммуникативного взаимодействия, а следовательно, и продуктивного смыслообразования. Контактоустанавливающая тактика реализуется в консолидирующем типе диалога, особенность которого заключается в том, что он не несет самостоятельной смысловой нагрузки. Эта тактика использует такие структурные компоненты диалога, как приветствие, обращение, этикетные формулы. Каждый урок в школе начинается с установления контакта между учителем и учениками в ритуализованной форме. Учитель обязательно приветствует учеников, используя этикетные слова и обороты: «здравствуйте», «добрый день», «доброе утро». К этим словам могут присоединяться обращения: «ребята», «друзья мои», «юноши и девушки ».Ученики в ответ на приветствие учителя, согласно школьному этикету, обязаны встать, выражая тем самым ответное приветствие и свою готовность к занятию. Тактические ходы установления контакта прослеживаются в частом использовании учителем местоимений «мы»,«наш» (урок, тема), словосочетания «мы с вами». Обычным является употребление глаголов в форме первого лица множественного числа («записываем», «проверяем»); формы повелительного наклонения множественного числа глагола «давать»: «давайте прочитаем (вспомним, посмотрим)». Характерны для этой диалоговой тактики также такие вопросы-подсказки к ученикам, которые показывают значимость мнения, позиции школьников в ходе совместной деятельности («А как вы думаете?», «Вы согласны?»).
Все перечисленное нами позволяет выявить стремление к кооперации, так как предполагает коммуникативную и деятельностную «общность» педагога и учащихся.

На организационном этапе педагог может выбрать одну из указанных тактик либо применить последовательно. Этап «актуализация предпонимания» - переход к активизации усвоенных ранее знаний, умений, навыков учащихся, а также их личностного опыта и того «культурного фона», который уже существует в их сознании и который необходим для восприятия и понимания нового учебного материала. Как отмечает Е. Г. Белякова, на этом этапе необходимо создать ситуацию непонимания (незнания). «Предпонимание - это знание, основанное на предшествующем учебном и жизненном опыте детей» . Этап «актуализация предпонимания» сопоставим с этапом «актуализация знаний» в классической структуре урока. Учитель использует регулятивноконтролирующую диалоговую стратегию и диалоговую тактику «выявление общих пресуппозиций», что предполагает выявление того «культурного фона» учащихся, который необходим для понимания нового учебного материала и осознания знания о незнании. Данная тактика реализуется через эвристическую беседу и беседу-рассуждение (См. рис.9)

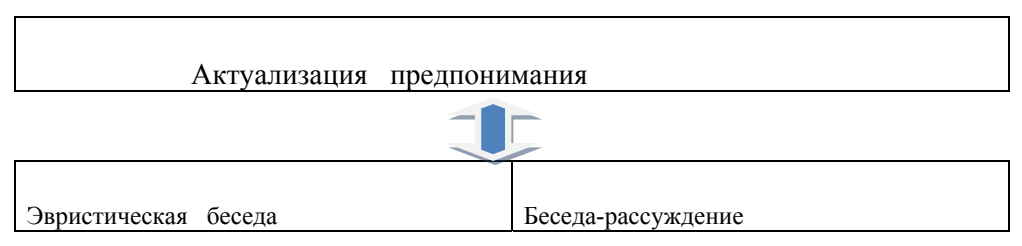

Рисунок 9. Актуализация предпонимания. 
Этап «освоение нового знания», в зависимости от объема содержания новой темы, может длиться в течение одного или нескольких уроков. Данный этап предполагает использование информационно-смысловой стратегии, которая последовательно реализуется в трех тактиках: первичное изучение учебного материала; погружение в учебный материал с привлечением культурного опыта субъектов; «вживание» в учебный материал и экстраполяция пройденного на свой личный опыт.Диалоговой тактике «первичное изучение учебного материала» соответствует такой тип учебного диалога, как диалогистолкование, форма реализации - эвристическая беседа, в ходе которой происходит первичное освоение знания, его интерпретация. Обратимся к примеру использования данной тактики на уроке литературы в 8-м классе:

\section{Первичное изучение учебного материала}

Учитель: Скажите, пожалуйста, где происходит действие повести «Ася»?

1-й ученик: Основное действие - в Германии.

Учитель: Поточнее, пожалуйста.

1-й ученик: В маленьком городе на Рейне.

Учитель: Интересно, а почему же не в России, ведь герой повести -русский человек?

1-й ученик: А может быть, это надо, чтобы показать контраст?

Учитель: Так, так, интересно, какой контраст?

2-й ученик: Да, нет, мне кажется, что автор хочет показать,

что ... ну, русский человек оказывается в чужой стране, в

изоляции, что ли. То есть автор помещает героев в чуждую им среду, с тем чтобы яснее выявить их характеры.
В приведенном диалоге мы с помощью эвристической беседы раскрываем объективную учебную информацию. Учителю важно проверить осознанность усвоения текста, акцентировать внимание учащихся на важных вопросах, необходимых для понимания всего произведения. При этом педагог задает вопросы, не только проверяющие первичное понимание текста учениками, но и инициирующие мышление учеников. Согласно таксономии Б. Блума, уровень этого диалога соответствует мышлению на уровнях «знание» и «понимание». Необходимо отметить важность создания ситуации, при которой у учащихся появится «знание о незнании» и потребность в дальнейшем понимании проблемы, где посредником в осмыслении выступит учитель.Следующей диалоговой тактике, используемой нами в изучении новой темы, «погружение в учебный материал с привлечением культурного опыта субъектов» - соответствует так называемый диалог-включенность. Формы реализации - беседа, дискуссия, диспут.

Часто ученики при ответе на вопрос учителя ориентируются на формулировку, т. е. на «вербальную составляющую», которая помогает им найти ответ в тексте. При этом они часто не вдумываются в вопрос. Для того чтобы помочь школьникам объективно оценить содержание текста, педагог должен задавать такие вопросы, которые потребуют от них другой формулировки, иного выражения того же содержания. Несмотря на то, что ответы на эти вопросы можно найти в тексте, формулировка вопроса, который задает учитель, должна отличаться от формулировок текста учебника. Подготовить такие вопросы для учителя, как правило, труднее, но они помогают ученику более точно интерпретировать текст на уровне анализа знаний. 
В ходе беседы и дискуссии нам необходимо задавать вопросы, инициирующие привлечение знаний, личностного жизненного опыта учащихся, позволяющие активно выразить собственное мнение по изучаемому вопросу, например: «Как ты думаешь, в чем заключается поэтапное применение риторических вопросов и кольцевой рифмы в произведении О.Сулейменова« Волчата?», «Чья жизненная позиция - Обломова или Базарова - ближе лично тебе. Почему?», «Были ли у тебя в жизни ситуации как у героев книг Крапивина: когда приходится выбирать между помощью другу и собственным благополучием?», «В каких произведениях литературы вы встречали образ «маленького» человека?» и тд.

Таким образом, учащиеся как бы ставят себя на место литературного героя, представляют себя в ситуации художественного произведения (если, конечно, речь идет о литературе), на месте исторической личности ( прототипа реальной исторической личности в художественном произведении), в ситуации той или иной исторической эпохи (если речь идет об историческом произведении). Нам очень важно, при использовании рассматриваемой тактики, сформировать такое отношение к новому материалу, когда учащиеся начинают чувствовать «близость» с изучаемыми событиями и перестают воспринимать учебный материал как набор сухих и отрешенных от жизни фактов и событий. Полезно проведение аналогий, сравнений, олицетворений, риторических вопросов, аллегорий и приведение аналогичных ситуаций из других художественных произведений и/или других исторических эпох. Именно поэтому тактика «погружение в учебный материал с привлечением культурного и жизненного опыта обучающихся» реализуется через диалог-включенность.
Важной особенностью реализации всех перечисленных диалоговых стратегий является формирование установки на терпимое отношение к чужому мнению, к высказываниям других. Недопустимы насмешки, грубость, резкость. Педагог в это время является активным наблюдателем: он и сам участвует в дискуссии, и в то же время отмечает в листе наблюдений характер высказываний учащихся, а любая агрессия по отношению к партнеру и по отношению к изучаемому материалу останавливается в корректной форме.

Использование тактики «вживание в учебный материал и экстраполяция пройденного на свой личный опыт» возможно не во всех учебных ситуациях - как правило, это зависит от характера содержания обучения, от творческого потенциала учащихся в группе, от степени уже имеющейся «погруженности» в изучаемый материал. Реализация этой тактики осуществляется через моделирование проблемных ситуаций, через участие субъектов диалога в дидактической игре и т. д. Педагог использует вопросы типа «Автор и ты» - ответов на которые нет ни в рассказе педагога, ни в параграфе учебника. Ученик должен подумать о том, что сообщил автор и для чего это нужно лично ему. Вопросы типа «По-моему» также подразумевают размышления при перенесении изученного на свой личный опыт. В общем, эти вопросы формулируются по принципу «А как бы ты поступил...?» На них нельзя ответить на основании текста. Ученик должен дать ответ, опираясь на собственный опыт и самостоятельное осмысление изученного учебного материала.

На этапе изучения новой темы «применение знания» рекомендуется использование оценочной стратегии, которая реализуется в трех тактиках: выявление ошибоч- 
ных толкований, утверждение правильных толкований, эмотивная оценка. Учащиеся должны попытаться использовать полученные знания в новых социальных контекстах, в которых могут определять свои ценностные приоритеты, жизненные задачи. Педагог может предложить учащимся смоделировать различные жизненные ситуации, для решения которых потребуется применить полученное знание. Как отмечает Е. Г. Белякова, важным условием реализации этого этапа является поддерживающая среда (педагоги, родители), формы и методы, обеспечивающие возможность использования полученного знания в творческой деятельности .

После проведения этапного контроля, который может быть реализован как в виде беседы, так и в других формах (сочинение, изложение), учитель применяет тактики «выявление (отрицание) ошибочных толкований» и/или «утверждение правильных толкований». В первом случае можно прибегнуть к аргументирующему диалогу, цель которого - убедить в корректной форме ученика (учеников) в ошибочности взглядов, установок, мировоззрений, сформировавшихся на основе изученного учебного материала. Такой диалог предполагает использование доказательств, аргументов как со стороны педагога (Это не совсем так, потому что..), так и со стороны учащихся (Я так думаю, потому что., Я уверен, что я прав, потому что.), а также вопросов, инициирующих обсуждение разных точек зрения (Почему ты именно так считаешь?Объясни, пожалуйста, поподробнее... и т. д.).

Диалоговая тактика «утверждение правильных толкований» реализуется в диалоге-одобрении, цель которого - подтверждение правильности взглядов, установок, высказанных учеником, а также закрепление действий, по- ступков, осуществленных учащимися. На данном этапе важно создать ситуацию успеха и убедить учащегося в правильности усвоенных им смыслов.

Тактика «эмотивная оценка» является неотъемлемой составляющей дидактического взаимодействия, она pеaлизуется учителем практически на каждом уроке, часто в «воспитательных целях» и, как правило, содержит эмоциональный «подтекст». Использование этой тактики обусловлено потребностью учителя проводить коррекцию поведения учащихся в определенных ситуациях, вносить значимые изменения в их отношение к учебной деятельности и т. п., т. е. постоянно осуществлять контроль за происходящим, стимулируя учеников к «позитивной» учебной деятельности.

Эмоции - особая, своеобразная форма познания и отражения действительности, так как в них человек выступает одновременно и объектом, и субъектом познания, эмоции связаны с потребностями человека, лежащими в основе мотивов его деятельности. Реализация апеллятивной функции речевых средств в эмоциональном плане (по Н. С. Трубецкому), которая проявляется в возбуждении в собеседнике определенных чувств, является непременным атрибутом диалогового взаимодействия. Можно сказать, что эмотивность, наряду с аксиологичностью, является «обязательной» составляющей смыслового пространства любого общения.

Последний этап - «коррекция процесса усвоения смыслов» - в большинстве случаев необходим при изучении новой темы. Суть любых образовательных технологий (В. В. Гузеев, Г. К. Селевко) заключается в возможности коррекции неправильного понимания, в «возвращении» ученика на этап освоения нового для формирования пра- 
вильной модели мира. Тактика «коррекция модели мира» реализуется в реинтерпретирующем диалоге, который организуется педагогом после использования тактики «выявление ошибочных толкований». Аргументирующий тип диалога применяется индивидуально или в небольших группах учащихся.

Последовательная, системная реализация описанных диалоговых стратегий при освоении школьниками нового учебного содержания -важная составляющая процесса обучения. Именно диалог как основная форма коммуникативного взаимодействия членов современного социума позволяетучителюуспешно решатьсамыесложныедидактическиезадачи в образовательной средешкольногоурока. Учитывая современную организацию интерактивного способа обучения,особую важность в педагогическом подходе приобретают групповые(коллегиальные) формы работы, поэтому от того, как преподаватель сможет организовать работу, зависит и качество обучения. Мы считаем, что диалоговое обучение, а именно диалогическая беседа, приносит большую пользу в развитии и обучении детей, в формировании правильной речи.

Работая в группе, в процессе нашего наблюдения за подростками, мы сделали выводы о том, что они,естественно, очень любят делиться своими впечатлениями на разные темы из жизненного опыта; рассказывают о том, что происходит у них в семье, о домашних питомцах, о любимых занятиях, хобби. Если не хватает терпения выслушать собеседника, тогда все начинают говорить одновременно. Обучающиеся задают много вопросов. Все это необходимо использовать педагогу в своих целях, а именно:
- развитие интеллекта и мышления;

- результативность в обучении;

- развитие навыка говорения, обсуждения и аргументации;

- выражение собственного понимания темы;

- понимание того, на какой стадии обучения находятся учащиеся;

- развитие коммуникативных навыков;

- развитие умения вести диалог

Мы считаем, что для достижения поставленных целей, необходимо внедрение в учебный процесс парной и групповой работы через диалогическую беседу, целью которой является формирование речи учащихся, что является актуальной проблемой обучающихся более старшего возраста.

Взяв за основу теорию Выготского «Зона ближайшего развития», где учащийся обучается при поддержке взрослого или более способного ученика, в процессе социального взаимодействия, нам можно выделить три метода реализации диалогового обучения

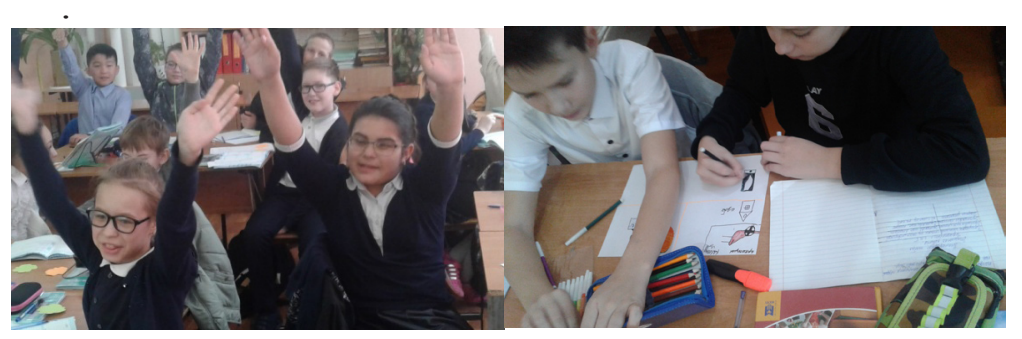




\section{1. Кумулятивная беседа}

«Это беседа, в которой происходит обмен знаниями, когда каждый принимает и соглашается с тем, что говорят другие; участники беседы терпимы по отношению к идеям других; идеи повторяются и разрабатываются, но не всегда тщательно оцениваются». Мерсер.

Кумулятивную беседу можно использовать на каждом занятии из серии последовательных уроков, с целью обмена знаниями, развития навыка говорения, выражения собственного понимания через толерантное отношение к пониманию других участников беседы.

Как можно выстроить кумулятивную беседу?

- работая в паре, дети отбирали карточки, с изображением литературных персонажей, объясняя и доказывая свой выбор (Это герой басни И.А. Крылова «Волк на псарне», ловчий, являющийся прототипом реальной исторической личности,М.Кутузова ). Учащиеся по очереди отбирали карточки и обменивались знаниями. Преимущество данного задания было в том, что учащийся выбирал ту карточку,, которую мог охарактеризовать. В случае если он не сможет охарактеризовать фигуру, он получит информацию от товарища, где происходи обмен опытом и знаниями.

- работая с произведением К.Г.Паустовского «Телеграмма», в групповом упражнении «карусель», по очереди комментируя действия главных героев. В этом упражнении каждый учащийся внес свое личное мнение, вклад в общее дело, где проихсодил обмен опытом и знаниями.

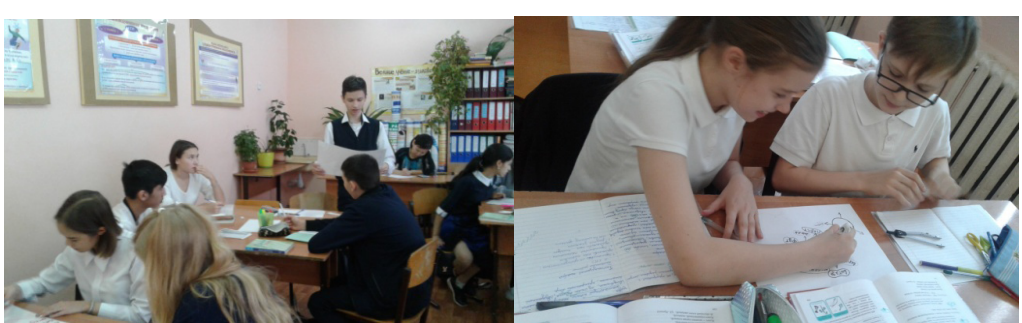

2. Исследовательская беседа.

Через исследовательскую беседу, «в которой каждый прилагает уместную информацию; идеи каждого расцениваются как полезные, но проходят тщательную оценку. Участники задают друг другу вопросы. Участники спрашивают и обосновывают, что сказано; таким образом, обоснование прослеживается в беседе. Участники группы стремятся достичь согласия (хотя важен не факт достижения согласия, а стремление к нему)». Мерсер.

Исследовательская беседа была использована на занятиях с целью развития познавательных потребностей учащихся, умения работать с различными источниками информации, и понимания важности самостоятельно полученных результатов.

Как правильно подойти_ исследовательской беседе?

- при составлении карты опыта, когда дети, работая в команде, предлагают уместную информацию, анализируют ее и отбирают нужную.

- при решении проблемы ;

- отбор и сортировка информации (при подготовке к уроку-исследованию дети дома работали с журналами, фото, газетами, интернетом, сортируя и отбирая нужную информацию для занятия) - это задание предлагалось «талантливым» детям, с целью донесения этой информации остальным членам группы; 
- на уроке-исследовании (где они обсуждали в группах ту информацию, которую подготовили дома (талантливые), работали с информацией, которую подготовил учитель (все), отбирали главное и составляли карту опыта);

- при составлении и отборе вопросов для интервью на уроке исследовании.
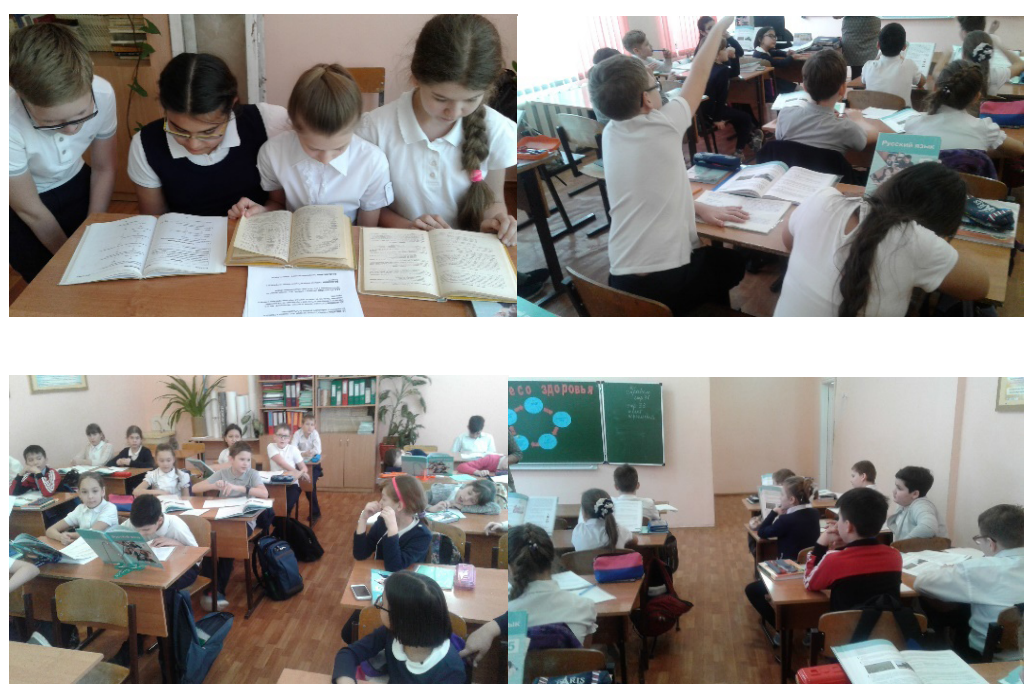

3. Беседа - дебаты, «в которой существует расхождение во мнениях и каждый приходит к своему решению; предпринимается небольшое число объединить ресурсы; общение часто происходит по типу «Да», это так!» - «Нет, не так!»; атмосфера скорее конкурентная, нежели ориентированная на сотрудничество».

\section{Мерсер.}

Беседу - дебаты мы планировали в серии уроков, потому как посчитали, что ученики справятся с этим заданием, выполняя отбор при сортировке карточек с профессиями людей и отбирая среди них направления, не 78 связанные с действиями, группы разошлись во мнениях. Одна группа посчитала, что профессия художника не имеет отношения к лирике, а две другие, с ними не согласились, тогда каждый доказывал свою точку зрения и приводил аргументы.

Было понятно, что обучающиеся способны на большее, поэтому не нужно бояться пробовать и экспериментировать, поэтому беседа - дебаты, на данный момент, необходимая часть учебного процесса.

Что дает развитие диалогической беседы?

$>$ ученик учится вести диалог;

$>$ ученик учится выражать свои мысли;

$>$ ученик учится слушать, анализировать, синтезировать, выделять главное и делать выводы;

$>$ формируются способности к обобщению, расширению кругозора, обогащения словарного запаса;

$>$ ученик развивает в себе умение учиться у других детей

$>$ в процессе диалогической беседы у ребенка развивается речь!

План развития диалогового обучения:

1.Создание атмосферы сотрудничества, с целью взаимодействия работы в паре и группе;

2.Подбор интересных заданий, с целью мотивации;

3.Вовлечение всех учащихся в учебный процесс;

4. Включение беседы - дебаты в план занятий;

5.Совершенствовать работу в группе и паре.

Если мы будем следовать намеченному плану, вовлекая каждого обучающего в совместную деятельность через три вида диалогической беседы, то главная цель диало- 
гического обучения - развитие речи будет нами достигнута. Главное - не останавливаться на полпути: пробовать, ошибаться, совершенствовать, модифицировать...в общем - менять свое мировоззрение и становиться педагогом 21 века новой формации в современном мире (См. рисунок 10)

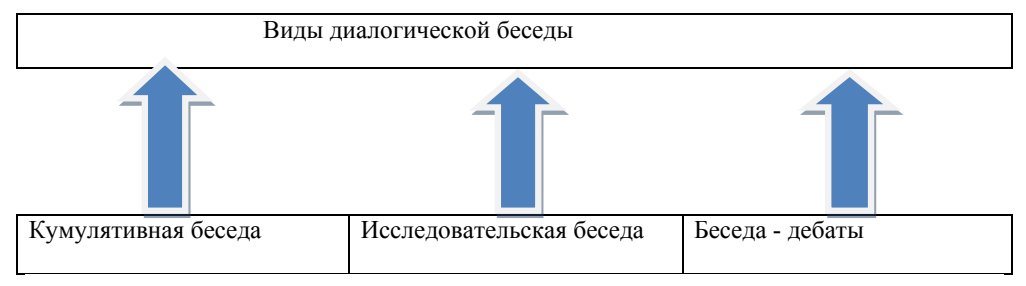

Рисунок 10. Виды диалогической беседы

Но учить всем этим умениям сразу, в одинаковой степени невозможно. Поэтому на каждом уроке должна быть четко определена задача обучения. Планировать,согласно программе обучения, развитие речи учащихся рекомендуется на длительный срок - лучше всего на год. При этом условии в плане могут быть предусмотрены различные виды диалога, различные темы. Таким образом, в развитии связной речи учащихся есть ряд ясных определенных задач, последовательное решение которых и создает систему в нашей,столь увлекательной, работе.

\section{ЗАКЛЮЧЕНИЕ}

Работа была направлена на развитие связной речи учащихся, совершенствование коммуникативных умений, что облегчало общение подростков, а значит, способствовало решению проблемы формирования речевой компетенции .

В результате проведенного опытного обучения (учитываем контрольные и экспериментальные классы) учащиеся научились выражать свои чувства и адекватно их описывать, формулировать свои мысли и выражать их в развернутой форме, высказывания школьников стали более логичными, их словарь обогатился эмоционально - оценочной лексикой, отражающей чувства человека. Подростки приобрели новые стратегии решения коммуникативных проблем, научились более адекватно оценивать себя, других людей и ситуацию в целом, стали предпринимать активные действия для изменения своего языкового общения в группе.

Итак, владение высокой культурой речи является важным условием профессионального успеха личности. Неправильная, примитивная речь может пагубно сказаться и на оценке профессиональной деятельности молодого человека. Культура речи - сложное и многоаспектное явление, поэтому в процессе исследования мы рассматривали несколько областей научного знания: вопросы культуры речи с точки зрения педагогики (педагогического диалога), психологии образования, эстетики, языкознания, литературоведения. Основу формирования высокой культуры речи составляет существующее в сознании человека представление о речевом идеале, образце, в соответствии с которым и развивается нормативная богатая речь. Под- 
линными речевыми образцами для школьников являются литературные художественные тексты, являющиеся моделью для создания диалога, где образцом будет прежде всего повествование самого автора

Перспективным представляется выяснение того, как преломляется проблема коммуникации в старших классах, разработка методики для повышения эффективности диалогового общения подростков, исследование возможности соединения психологической коррекции и развитие индивидуального языкового стиля учащихся.

Таблица 6 Функции общения и решаемые в ходе их реализации задачи речевой компетентности

\begin{tabular}{|l|l|l|}
\hline Речевые функции & $\begin{array}{l}\text { Коммуникативные за- } \\
\text { дачи }\end{array}$ & $\begin{array}{l}\text { Коммуникатив- } \\
\text { ные умения и } \\
\text { навыки }\end{array}$ \\
\hline $\begin{array}{l}\text { Информационная } \\
\text { функця }\end{array}$ & $\begin{array}{l}\text { запросить информацию } \\
\text { сообщить информацию } \\
\text { объяснить информа- } \\
\text { цию воспринять и } \\
\text { понять полученную } \\
\text { пнформацию }\end{array}$ & $\begin{array}{l}\text { продуктивных } \\
\text { речевых умений } \\
\text { в говорении и } \\
\text { письме }\end{array}$ \\
\hline Побудительная & $\begin{array}{l}\text { побудить к чему-либо } \\
\text { попросить о чем-либо } \\
\text { предложить что-либо } \\
\text { посоветовать догово- } \\
\text { риться о чем-либо вос- } \\
\text { принять побуждение и } \\
\text { отецептивных } \\
\text { речевых умений } \\
\text { в восприятии } \\
\text { речи на слух и } \\
\text { чтении }\end{array}$ \\
\hline
\end{tabular}

\begin{tabular}{|l|l|l|}
\hline $\begin{array}{l}\text { Эмоционально- } \\
\text { оценочная } \\
\text { функция }\end{array}$ & $\begin{array}{l}\text { выразить мнение, оцен- } \\
\text { ку выразить чувства, } \\
\text { эмоции ощутить удо- } \\
\text { вольствие/неудоволь- } \\
\text { ствие и другие чувства } \\
\text { от воспринятой инфор- } \\
\text { мации }\end{array}$ & $\begin{array}{l}\text { оценочных ре- } \\
\text { чевализе и срав- } \\
\text { нении }\end{array}$ \\
\hline $\begin{array}{l}\text { Аргументативная } \\
\text { функция }\end{array}$ & $\begin{array}{l}\text { Найти аргумент, со- } \\
\text { ответствующий теме } \\
\text { (проблеме) эссе или } \\
\text { модели высокохудоже- } \\
\text { ственного текста, дока- } \\
\text { зать, убедить }\end{array}$ & $\begin{array}{l}\text { доказательных } \\
\text { речевых умений } \\
\text { вопользовании } \\
\text { цитасосвет- } \\
\text { ствующих теме. }\end{array}$ \\
\hline
\end{tabular}

На основе анализа функций общения мы создали алгоритм смены диалоговых стратегий в контексте урока в общеобразовательной школе, что предполагает выявление того жизненного опыта учащихся, который необходим для понимания нового учебного материала. Данная стратегия реализуется через эвристическую и кумулятивную беседу, беседу-рассуждение( См.таблицу 7)

Таблица 7. Алгоритм актуализации понимания в диалоговом обучении (Обсуждение новой темы, нового материала )

\begin{tabular}{|l|l|}
\hline Актуализация понимания (Обсуждение новой темы) \\
\hline Эвристическая беседа & Беседа- \\
(первичное изучение учебного & дебаты(рассуждение) \\
материала)10 мин & (погружение в учебный \\
Кумулятивная беседа & материал с привлечением \\
(обсуждение нового материала) & культурного опыта \\
10 мин & субъектов 20 мин) \\
\hline
\end{tabular}


Так как этап освоение нового знания, в зависимости от объема содержания новой темы, может длиться в течение одного или нескольких уроков и предполагает использование информационно-смысловой стратегии, которая последовательно реализуется в трех тактиках: первичное изучение учебного материала; погружение в учебный материал с привлечением культурного опыта субъектов; погружение в учебный материал и экстраполяция пройденного на свой личный опыт, то реализация этой тактики осуществляется через моделирование проблемных ситуаций, через участие субъектов диалога в активном обсуждении. Т.е., обучающийся должен дать ответ, опираясь на собственный опыт. На основе тактики актуализации понимания, выделяем три метода реализации диалогового обучения (См. таблицу 8)

Таблица 8.

Три метода реализации диалогового обучения

\begin{tabular}{|l|l|l|}
\hline Беседа-дебаты & $\begin{array}{l}\text { Кумулятивная } \\
\text { беседа }\end{array}$ & $\begin{array}{l}\text { Исследовательская } \\
\text { беседа }\end{array}$ \\
\hline -существует большое & -принятие и со- & -уместная инфор- \\
расхождение во мнениях & гласие с мнением & мация \\
и каждый приходит к & других & -идеи проходят тща- \\
своему решению. & -толерантность & тельную оценку \\
-предпринимается не- & по отношению к & -поисковая беседа \\
большое число попыток & другим & -обоснование (аргу- \\
объединить ресурсы. \\
-атмосфера конкурент- \\
ная
\end{tabular}$\quad \begin{aligned} & \text {-идеи повторя- } \\
& \text { ются и разраба- } \\
& \text { тываются, но не } \\
& \text { оцениваются }\end{aligned}$

Итак, чтобы диалог сформировался и был действенным, в его основе должна быть проблема, которую структурируют открытые и проблемные вопросы, требующие 84 осмысления и обсуждения коммуникатором (преподавателем) и рецепиентом (учеником) и результат, т.е.обратная связь, выявляющая особенности смыслообразования в процессе диалогового обучения, соотносимого с уровнем учебного результата. Действенный диалог рассмотрен нами в кумулятивной, исследовательской беседе и беседе-дебатах. (См.рис 11)

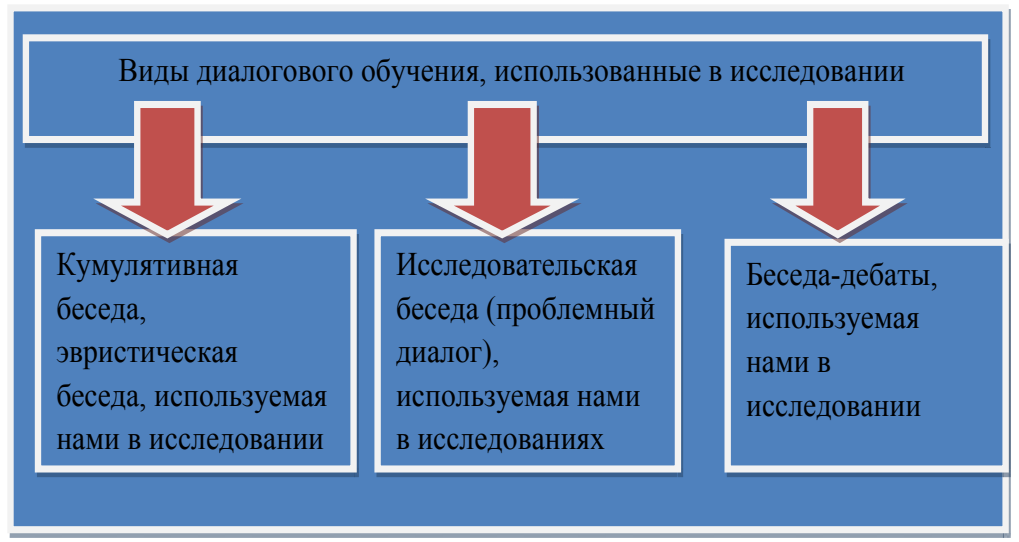

Рисунок 11. Виды диалогового обучения, использованные в исследовании

Итак, выделим несколько типов диалога, которые позволяют особым образом представить определенную модель, создать основу для переосмысления акта речевой коммуникации:

1. Духовный диалог. Для него свойственны глубокое понимание сущности проблемы, высокий уровень культуры диалогического взаимодействия.

2.Смыслотворческий диалог, активно включающий участников в поиск новых смыслов, в процесс определе- 
ния системы индивидуальных ценностных ориентации.

3.Рефлексивный диалог, позволяющий оценить собственный потенциал.

Экспериментальная работа позволила сделать вывод о возможности формирования коммуникативной компетенции учащихся за счет разработки и широкого внедрения в учебный процесс учебных диалогов. Было выявлено, что учебный диалог является эффективным средством повышения коммуникативной компетенции. При целенаправленном использовании учебного диалога у обучающихся формируются умения, составляющие основу коммуникативной компетенции: умение четко излагать свои мысли, формулировать проблему и выдвигать гипотезу, умение внимательно слушать и наблюдать, задавать вопросы и участвовать в обсуждении, а также владеть разными видами диалога, умение определять точку зрения автора, выделять аргументацию; главную мысль текста; выделять причинно-следственные связи в устных и письменных высказываниях; структурировать материал; создавать устные и письменные тексты различных стилей с учетом замысла, адресата, и ситуации общения; участвовать в дискуссии.

\section{ВЫВОДЫ И ПРЕДЛОЖЕНИЯ, РЕКОМЕНДАЦИИ ДЛЯ ПРАКТИКИ.}

Роль учебного диалога в развитии коммуникативной компетенции учащихся определяется его содержанием и качеством, способствующими ведению открытого и глубокого по содержанию разговора. Кроме того, школьников необходимо учить полноправному участию в диалоге, формировать у них такие речевые умения, как: понимание темы разговора, следование основной мысли, умение адекватно реагировать на реплику партнера, аргументирование тезиса, подбор иллюстративного материала, ввод дополнительной информации, умение делать вывод и давать оценку рассуждению партнера по диалогу. «К тому же учебный диалог, как один из видов диалогической речи, имеет свою специфику и со стороны формы, и со стороны содержания, поэтому при его ведении возникает ряд трудностей: вычленение особого предмета разговора, связанного с такими многослойными историко-культурными явлениями, как язык и литература; оперирование знаниями широкого диапазона; соблюдение логики мысли, аргументативную часть которой учащимся еще предстоит освоить; ввод информации; отбор приемов, с помощью которых она дается детям и становится основой диалога; способы выработки оценки содержания выступления каждого ученика со стороны учителя и со стороны учащихся.

Трудность проведения уроков-диалогов может быть большей или меньшей в зависимости от владения учителем техникой педагогического общения, выбора им педагогической позиции, создания мотивации к участию в диалоге, свободы, гибкости или жесткости диалога, учета 
психологии подростка и специфики детской и подростковой речи, а также использования на уроке богатого по содержанию материала» .

Только в этом случае учебный диалог даст учащимся:

- обогащенное содержание материала мировоззренческого характера, отобранного по принципу преемственности знания, межпредметных связей, научной и эстетической ценности;

- навыки грамотного, толкового и эмоционального выражения мыслей;

- развитие речи и мышления учеников;

- совершенствование межличностного диалогического общения.

Чтобы диалог был эффективным, необходимо на уроках отрабатывать диалогические приемы, которые помогут учащимся стать активными участниками учебных диалогов. В ходе исследования авторами была разработана система заданий, направленных на отработку диалогических приемов.

Известно, что при работе над приемом задавания вопросов используется не менее четырех видов заданий. Для того чтобы научить детей задавать вопросы, на уроках риторики учащиеся выполняли следующие виды заданий: задания на соотношение вопроса и ответа, задание на умение анализировать вопросы и ответы в предложенных диалогах, задания на составление таких вопросов к тексту, которые бы позволили увидеть тему текста с неожиданной стороны. При целенаправленном использовании учебного диалога у обучающихся формируются умения, составляющие основу речевой компетенции: умение четко излагать свои мысли, формулировать проблему и выдвигать гипотезу, умение внимательно слушать и наблюдать, задавать вопросы и участвовать в обсуждении, а также владеть разными видами диалога, умение определять точку зрения автора, выделять аргументацию; главную мысль текста; выделять причинноследственные связи в устных и письменных высказываниях; структурировать материал; создавать устные и письменные тексты различных стилей с учетом замысла, адресата. Например, эссе с элементами исследования.

В ходе диалога у учащихся формируется способность и умением вести его на разных уровнях.

На первом уровне как диалог с собственным $Я$, как общение с самим собой, собственным разумом - это личностный уровень.

На втором уровне диалог понимается как процесс взаимодействия качественно различных ценностноинтеллектуальных позиций (Я и другой) - это межличностный уровень.

Третий уровень диалога -мультидиалог -множественный одновременный диалог.

Условием овладения содержанием предмета диалога, необходимого на всех этапах его развития, является организация совместной деятельности педагога и детей, которая строится совместными усилиями педагога и учащихся и предполагает специфическое содержание и технологию ее развертывания.

В педагогической культуре существуют разные системы взаимодействия, в каждой из которых имеется свое понимание приема. В целом под приемом рассматривается ситуация, которая складывается из определенного содержания деятельности, ее целей и задач.

Деятельностная основа приема позволяет соотнести его с «действие», «операция», «способ деятельности». 
По итогам проведения экспериментальной работы нами разработаны рекомендации для педагогов гуманитарного цикла.

Рекомендации для учителей:

1) применять диалог на каждом уроке, помня, что благодаря ему, можно увеличить результативность в обучении;

2) помнить, что в основе диалога должна быть проблема, тогда он будет действенным;

3) ответ ученика - это его мнение и его надо уважать (каждое мнение значимо);

4) организовать работу в парах (коллегиально) и группах и создавать благоприятный климат (для сотрудничества) прислушиваться к мнениям учащихся;

Для учащихся:

1) учиться «слышать» друг друга;

2) грамотно формулировать вопросы;

3) приобретать навыки обсуждения и высказывания своих идей;

4) совместно решать проблемные вопросы;

5) проявлять чувство уверенности в себе, максимальную свободу развития и саморазвития учащихся;

6) от учения - запоминания информации к учениюразвитию;

7) вовлекать в работу слабоуспевающих учеников.

Применение такой формы организации учебной деятельности, как диалоговое обучение, позволяет разнообразить виды занятий, сделать их более интересными и запоминающимися.

Широкое внедрение группового диалога в учебный процесс дает новый импульс проблемному обучению, которое базируется на том, что усвоение программного материала будет эффективнее.

Таким образом, изучив и проанализировав научнометодическую литературу по проблеме, определив значимость и эффективность диалога как метода обучения, мы разработали пособие для обучения диалоговому общению.

При использовании педагогических приемов, креативного подхода к диалоговому обучению в формировании речевой компетентности мы достигаем того,что учащийся:

- владеет устной и письменной речью на казахском, русском и английском языках, использует способы речевой деятельности (слушание, говорение, чтение, письмо) для получения, отбора, обработки и передачи необходимой информации соответственно намеченным целям или для разрешения проблем;

- творчески выражает свои мысли, идеи в устной и письменной форме на трех языках, соответственно заданному контексту, как в учебном процессе, так и в повседневной жизни;

- развивает коммуникативные навыки для общения в любых жизненных ситуациях, для выражения собственного эмоционально ценностного отношения к окружающей действительности;

- осознает ценность языка как инструмента познания окружающей действительности и как средства для обоснования своей позиции при разрешении различных проблем;

- умеет ценить национальную и мировую литературу как часть мирового культурного наследия и рассматривает ее как основу для своего развития и совершенствования. 
Установленные ценности становятся стержнем повседневной деятельности учащихся и должны проявляться в их способностях:

- творчески и критически мыслить, чтобы принимать верные решения и созидательно участвовать в жизни общества;

- быть коммуникативным, творчески использовать разнообразные средства, чтобы действовать и работать в коллективе; развиваться как высокообразованная, творческая личность, обладающая навыками широкого спектра, а именно:

- творческого применения знаний;

- критического мышления;

- выполнения исследовательских работ;

- применения способов коммуникативного общения, включая языковые навыки;

- работы в группе и индивидуально;

- решения проблем.

Эти навыки широкого спектра позволят выпускникам общеобразовательных школ гармонично сочетать в себе культурные и речеведческие (лингвистические) ценности, проявлять функциональную грамотность и конкурентоспособность в любой жизненной ситуации. Они приобщают учащихся к исследовательской работе над текстом, а такая работа, в свою очередь, направлена на формирование создания развернутых речевых высказываний

Экспериментальная работа позволила сделать вывод о возможности формирования речевой компетентности учащихся за счет разработки и широкого внедрения в учебный процесс учебных диалогов.

Было выявлено, что учебный диалог является эффек- тивным средством повышения речевой компетентности. При целенаправленном использовании учебного диалога у обучающихся формируются умения, составляющие основу речевой компетентности:

- умение четко излагать свои мысли;

- формулировать проблему и выдвигать гипотезу;

- умение внимательно слушать и наблюдать;

- задавать вопросы и участвовать в обсуждении, а также владеть разными видами диалога;

- умение определять точку зрения автора;

- выделять аргументацию;

- главную мысль текста;

- выделять причинно-следственные связи в устных высказываниях. 

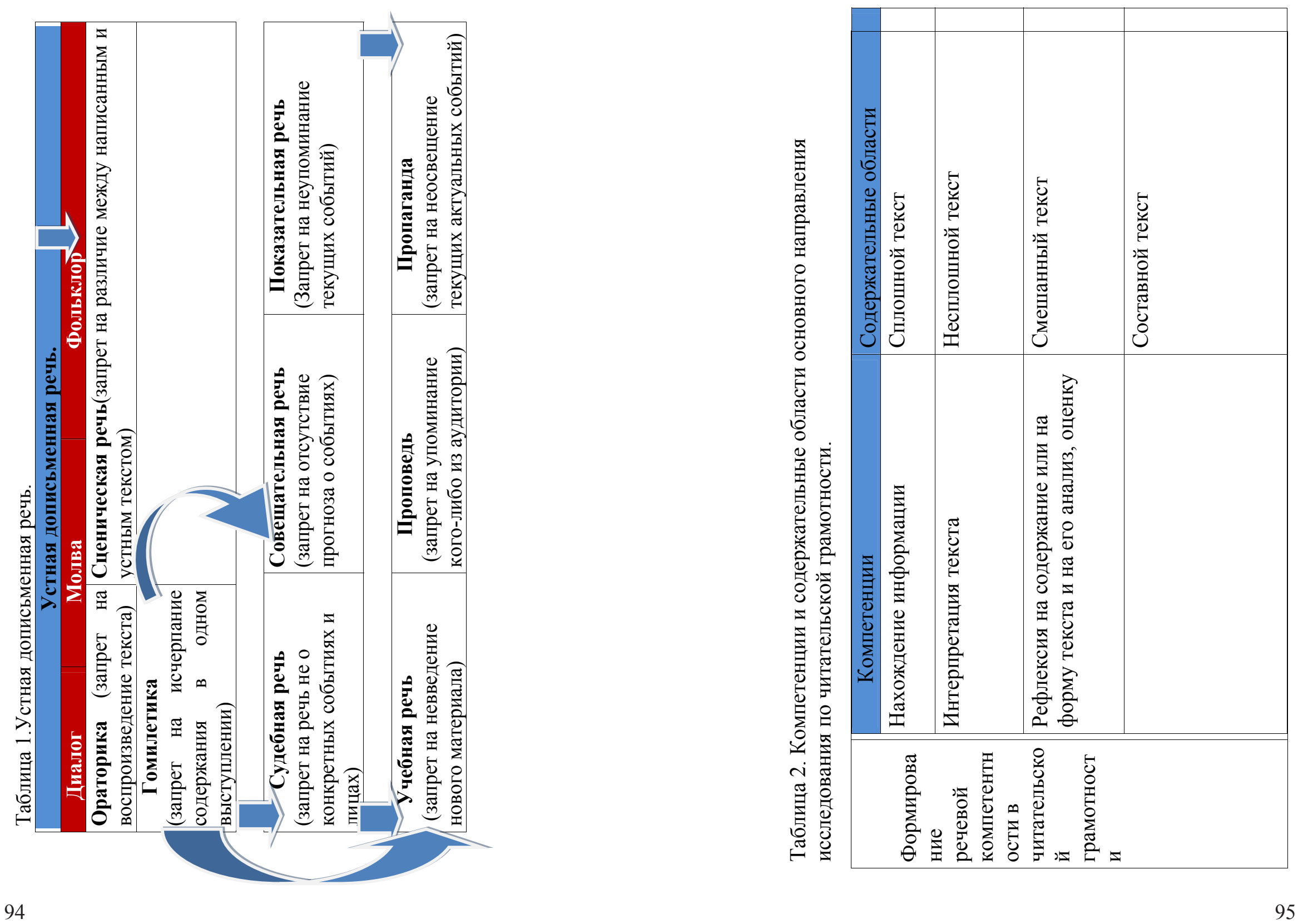

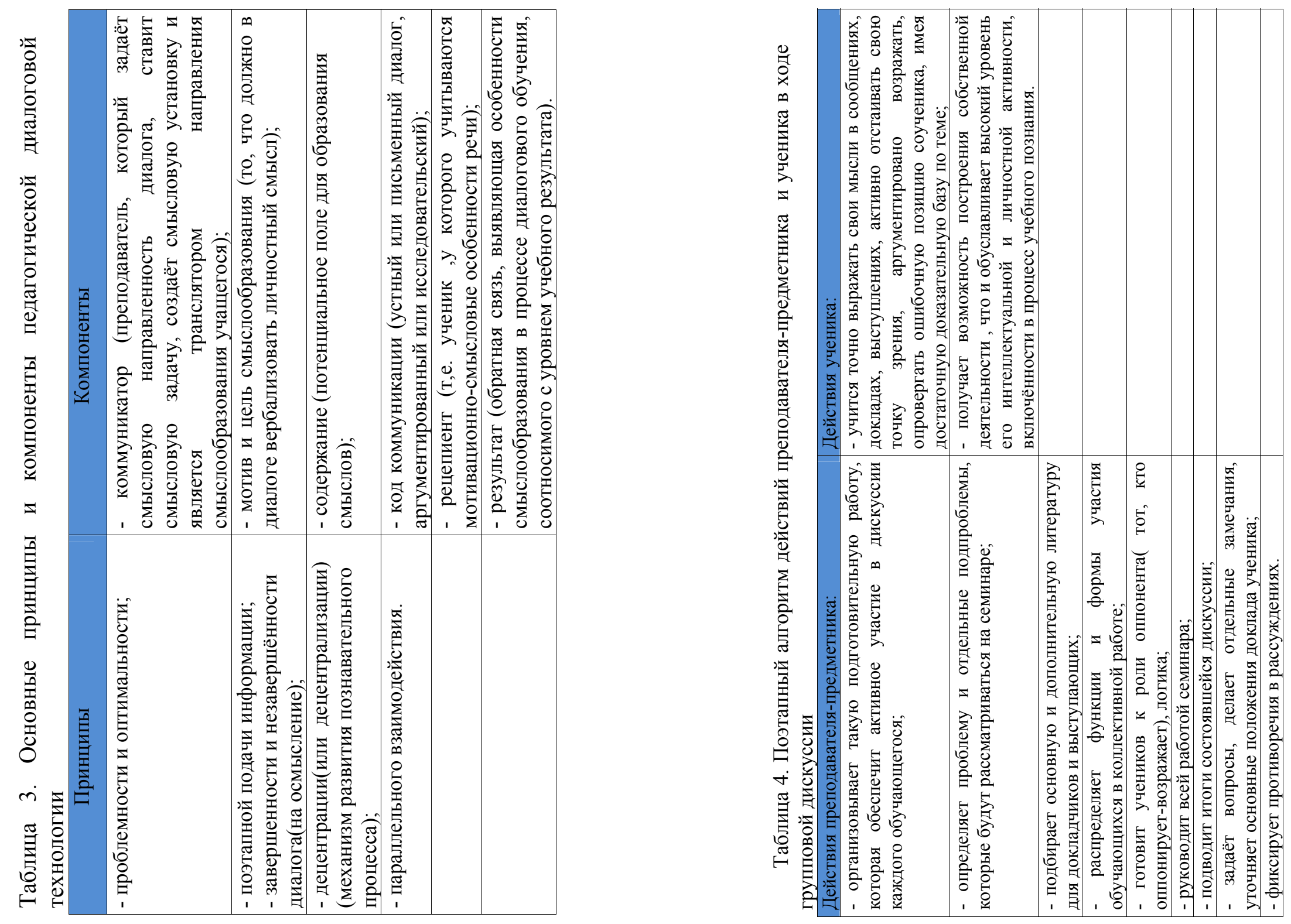

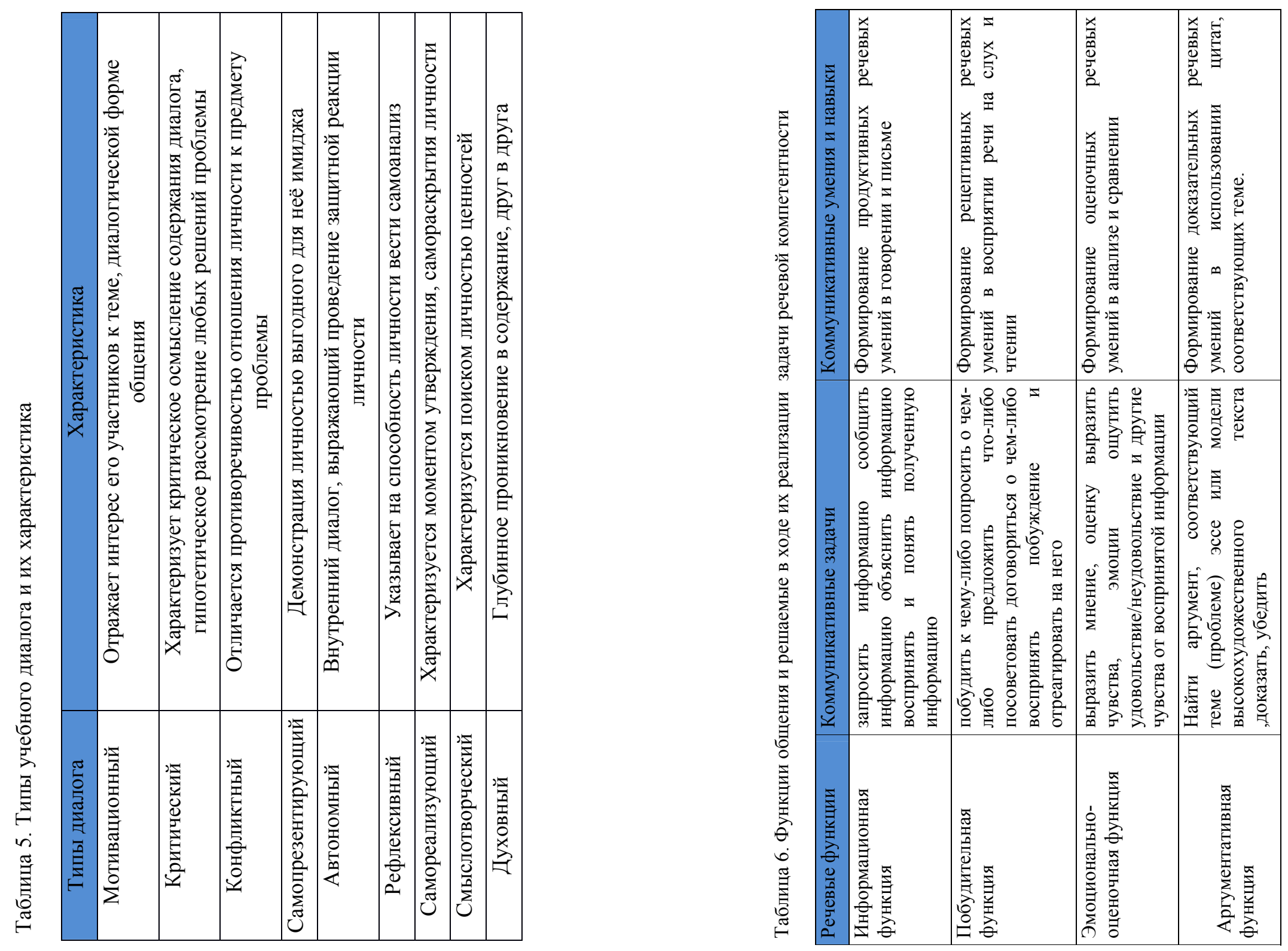

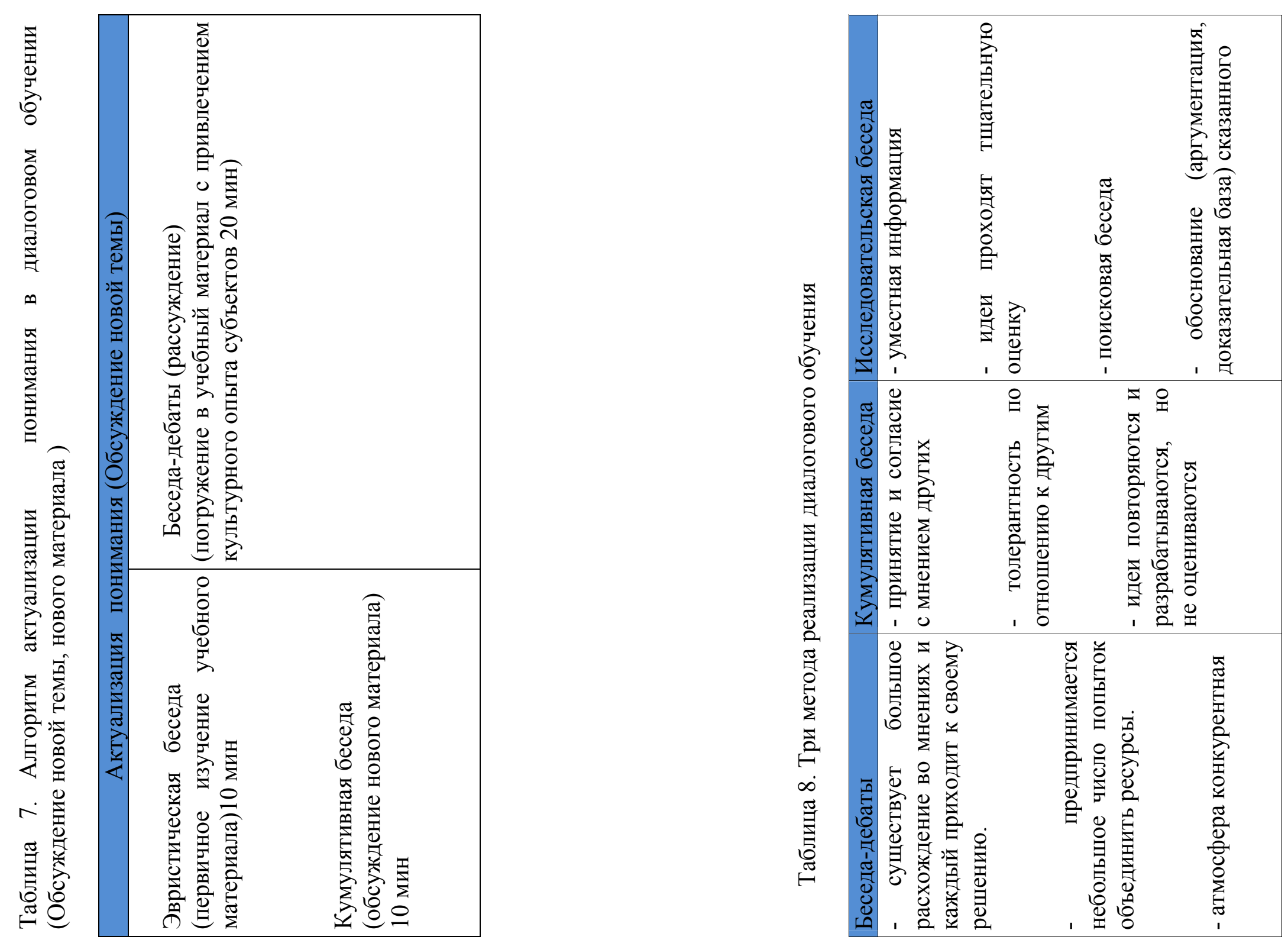

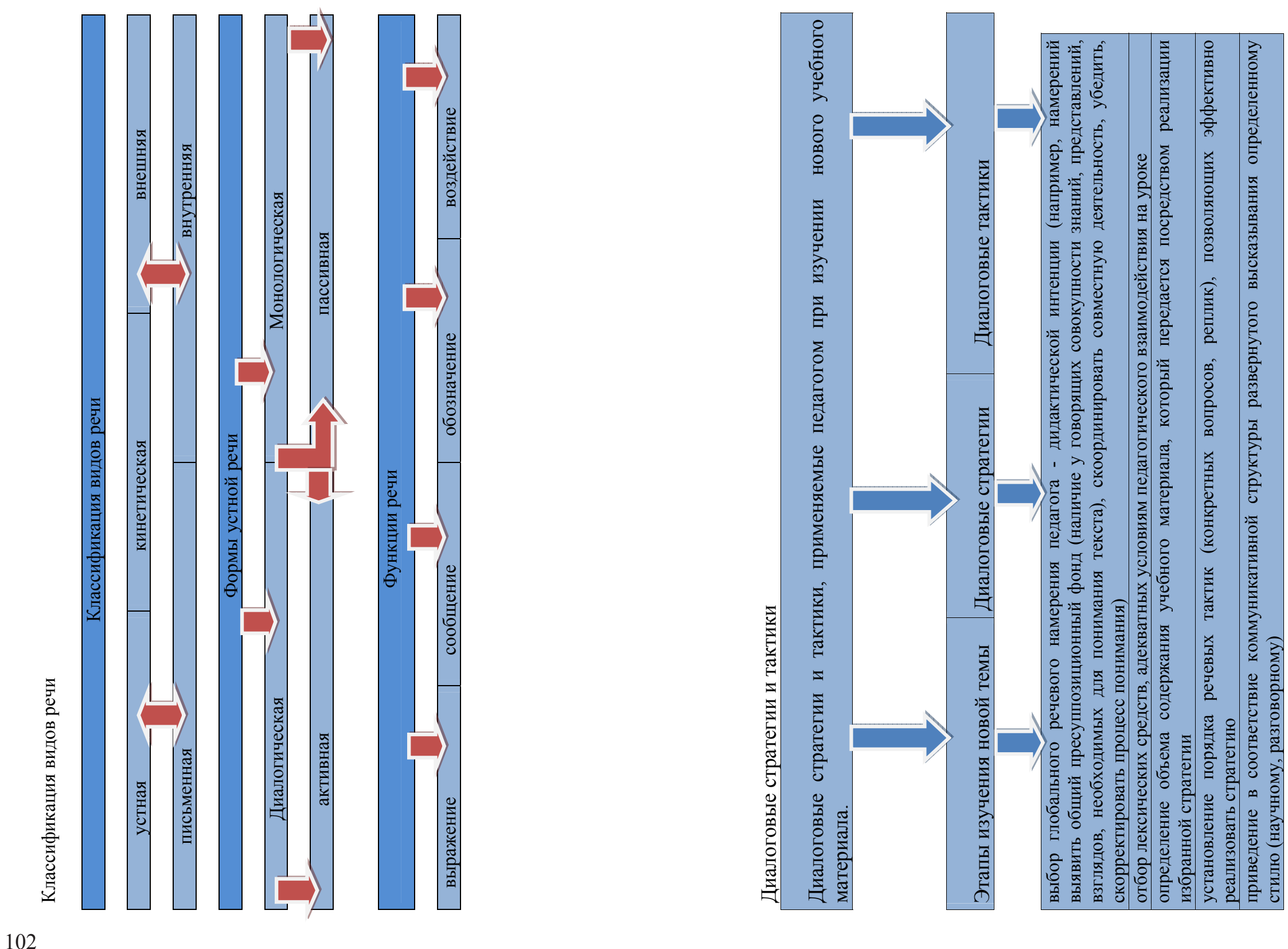


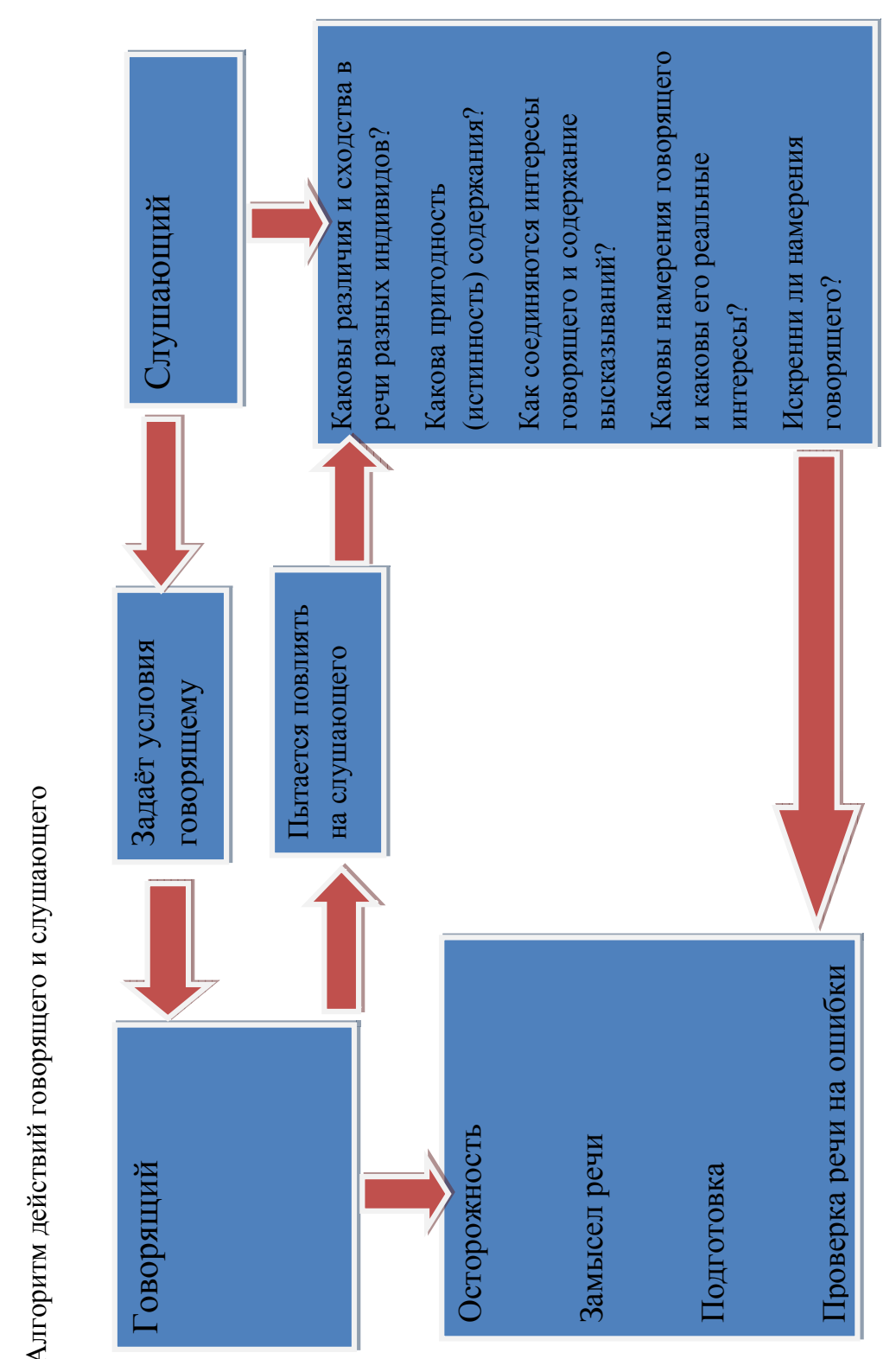

\section{Список использованной и рекомендованной} литературы:

1. Абрамова А.М. Образование в политике и политика в образовании// Вестник высшей школы. - М., 2005. № 1.

2. Ашурков В.Н. и др. Историческое краеведение. Учебное пособие. Под редакцией Г.Н.Матюшина и др. - М., Просвещение, 1980.

3. Борков В.Ф. Культура диалога/ В.Ф. Борков. - Минск, 2002.

4. Батракова С. Н. Педагогическое общение как диалог в культуре / / Педагогика. 2002. № 4. С. 27-33.

5. Белякова Е. Г. Смыслообразование в педагогическом взаимодействии. --Тюмень, 2008. 208 с.

6. Бережная Е.В. и др. Основы учебно-исследовательской работы. Учебник. 3-е издание. - М., Академия, 2007.

7. .Васильева А.Н. Основы культуры речи: учебное пособие. - М.: Высшая школа, 1998.

8. Вороницына Е.В.Диалог как средство организации учебной деятельности/Практика образования/-2010№4-C.16-20.

9. Гладкая И.В.Становление понятия» профессиональная компетентность» в теории профессионального образования /Педагогические исследования/-СнктПетербург-2011-С.130-132.

10. Голубева Е.В., Голубева И.В. Развитие языковой личности на уроках. Начальная школа.яз,1981.Факс.изд. №3, 2014. 
11. Давыдов В. В. Проблемы развивающего обучения. М., 2006.

12. Диалог. БСЭ, т. 8. - М., Советская энциклопедия, стр. 695.

13.Даль В.И.Толковый словарь живого великорусского языка:в 4 т.М.: Русс

14. Краткий словарь иностранных слов. Составитерь - С.М. Локшина. Изд.. 2-ое, стериотипное. - М., Советская энциклопедия, 1968.

15. Краткий психологический словарь. Под общей редакцией А.В. Петровского и др.. - М., Политич. литературы. 1985.

16. Кузнецова А.Н. // Русский язык в школах и в ВУЗах Казахстана. //(апрель-май.). «Формирование культуры речи в рамках триязычия. «с.3

17. Кузнецова А.Н.//Русский язык в школах и в ВУЗах Казахстана.//№ 3(4) Декабрь. «Исследование видов опроса подростков о формировании правильной речи.» с.13.

18. Кузнецова А.Н.//Русский язык в школах и в ВУЗах Казахстана.//№ 3(4) Сентябрь.»Патриотическое воспитание на уроках русского языка и литературы, как важнейший аспект формирования личности подростка.» с. 12

19. Кузнецова А.Н. //Русский язык в школах Казахстана.// №6 .Декабрь.. «Приемы кооперативного обучения как средства формирования правильной речи.» с.2.

20.Кузнецова А.Н. // Кузнецова А.Н //«Формирование культуры речи школьников в процессе лингвоэстетического анализа художественного текста» Русский язык в школах и в ВУЗах Казахстана.//№1 (4). <ruslit@mail.ru>c.3
21. Кузнецова А.Н.За чистоту речи.-2021г-219с.

22.Кузнецова А.Н.//Изложение как важный метод формирования культурной речи в обновленной системе образования// Алматы. респ. научно-методический журнал «Русский язык в школах и в ВУЗах Казахстана.» Выпуск№4.c.3

23. Кузнецова А.Н. //Формирование культуры речи через литературное краеведение// г.Алматы. респ. научнометодический журнал «Русский язык в школах и в ВУЗах Казахстана. «Выпуск № 2. 2018г.// . <rus-lit@, mail.ru>.c.10.

24. Кузнецова А.Н. //Приемы кооперативного обучения как средства формирования правильной речи.// г .Алматы. респ. учебно-методический журнал» Уроки русского языка и литературы в школе»№5 2017г..с.6.

25. Кузнецова А.Н. // «Исследование информационных технологий в формировании культурной речи подростков на уроках русского языка и литературы.// г .Алматы. респ. учебно-методический журнал» Уроки русского языка и литературы в школе» №2. 2017 г...c.3.

26. Кузнецова А.Н. //«Метод копирования высококультурной модели текста в обновленной системе образования»//Г.Астана. Научно-методический журнал. «Педагогический мир Казахстана» №5.2018г.с.22.

27. Кузнецова А.Н// «Формирование правильной речи подрастающего поколения через изучение произведений А.С.Пушкина.Алматы. респ. научно-методический журнал «Русский язык в школах и в ВУЗах Казахстана.» Выпуск№ 1. 2018г.// . <rus-lit@mail.ru>.c.33. 
28. Кузнецова А.Н. //«Формирование культурной речи в обновленной системе образования способом копирования высококультурной модели текста»// г .Астана. Научно-методический журнал. «Просвещение» Выпуск №2(8) (февраль 2018 г.)//с.22.

29. Кузнецова А.Н //»Формирование устойчивой культурной речи школьников в процессе анализа художественного текста.» г.Алматы. Республикалық Редакция <rus-lit@mail.ru>//pecп. научно-методический журнал «Русский язык в школах и в ВУЗах Казахстана.» Выпуск № 2. 2018г.// . >rus-lit@mail.ru>. c.10.

30. Кузнецова А.Н // «Краеведческие аспекты литературного Приуралья как этап в формировании культуры речи.» Г .Астана. Научно-методический журнал. «Просвещение» Выпуск №6(8) (ноябрь-декабрь 2017 г.)// .c. 23

31. Кузнецова А.Н // 2Формирование устойчивой культуры речи школьников в процессе лингвоэстетического анализа художественного г .Астана. Научнометодический журнал. . «Просвещение» Выпуск №4(6) (июль-август 2017 г.)//.c.48.

32. Кузнецова А.Н // «Изучение лирики А.С. Пушкина как один из аспектов формирования правильной речи у подростков.» // г .Астана. Научно-методический журнал. «Просвещение» Выпуск №5(7) (сентябрьоктябрь 2017 г.)// .c.3

33.Кузнецова А.Н.// Молодежный сленг в лингвистическом и социальном аспектах.// г.Алматы. респ. научнометодический журнал «Русский язык в школах и в ВУЗах Казахстана.» Выпуск№ 4. 2018г.// .c.22

34. «МӘНГІЛІК ЕЛДІН МӘРТЕБЕЛІ МҰҒАЛІМІ», КоЛлективный сборник краткосрочных планов г.Тараз
35. Кузнецова А.Н. Методическая разработка урокаконференции и презентации, по теме: «Абай и Пушкин - национальное достояние двух народов »

36. Монахов В. М. Технологические основы проектирования и конструирования учебного процесса. Волгоград: Перемена, 1995. 152 с.

37. Олешков М. Ю. Моделирование коммуникативного процесса: мо-ногр. - Нижний Тагил, 2006. 336 с.

38.Орфографический словарь русскогоязыка. Подредакцией С.Г.Бархуданова., И.Ф.Протченко., Л.И.Скворцова. издательство «Русский язык», 197.стр.477.

39. Орфографический словарь. 40-е изд. М.: Просвещение, 1988, стр. 222.

40.Орфографический словарь русского языка ; в 2 т.M.1985

41. Пересветов Н.Н.и др. Нетрадиционные формы и методы проведения практических занятий в вузе. Уральск, ТОО «Фирма Сервис+», 2009.

42. Психологическая служба школы. Методические рекомендации для работников образования. - Алма-Ата, 1991.

43. Снежков В. М. Психология коммуникации в организациях.(Учебное пособие.)- 1999г.-116 с.

44. Толковый словарь русского языка:в 4 т./ под редакцией Д.Н.Ушакова М.: ГИИНС, 1935-1940.

45. С Правдухиным по Уралу. Авторы-составители А.К. Комаров и др. _Уральск, ТОО, 2017.

46. Ушаков Д.Н.. Толковый словарь русского языка Ушакова. Litres- 2012.

47. Щербанов Н.М. Неизвестный Валериан Павлович Правдухин. Исследование о творчестве писателя. Уральск, ТОО «Полиграфсервис», 2010. 
48. Оспанова Я.Н. и др. Социально-исследовательская служба по проблемам патриотического воспитания молодежи и реализации государственной молодежной политики. Учебно-методическое пособие. - Алматы, Казахстанский институт молодежи, 2017.

49. Штец А. А., Шемигон Г. И. Учебный диалог в процессе формирования деятельности первоначального чтения // Молодой ученый. - 2015. - №12. - С. 829-831. - URL

50. Бадалова Л. Х. Проблемно-диалогическое обучение как способ решения учебной задачи // Молодой ученый. — 2016. — №11. — C. 1415-1417. — UR

51. Виноградова Н. Ф.. Учебный диалог - эффективный метод развития младших школьников.// Начальное образование. - 2010 - № 1.

52. Коджаспирова Г. М., Коджаспиров А. Ю. Педагогический словарь. - М.: Издательский центр «Академия». - 2003. - $176 \mathrm{c.}$

53. Мельникова Е. Л. Что такое проблемный диалог. // Начальная школа плюс до и после. - 2008. - № 8. C.3-8.

54. Каскрова А. А. Как улучшить навыки письма учеников 9 класса через диалогическое обучение? // Молодой ученый. — 2017. — №18.1. — C. 34-36. — URL

55. Программа курсов повышения квалификации педагогов общеобразовательных школ Республики Казахстан, учебное пособие-2018.

56. Граблина Н.В. Мастер-класс: технология учебного диалога на уроке литературы: по повести В.Г. Распутина «Прощание с Матерой» // Литература в школе, 2005, № 9. С. 37
57. Кузнецова А.Н Методические рекомендации для учителей предметников (на курсах ШМУ) при использовании приема «Странник» для расширения информации и формирования языковой компетенции.// Просвещение- №2-2019.-С.2-6 


\section{ПРИЛОЖЕНИЯ}

\section{Приложение №1.}

Инициативная группа кабинета русского языка и литературы СОШ № 3,под руководством Кузнецовой А.Н., проводит научно-методический поиск оптимальных путей формирования речевой компетенции у учащихся среднего звена путем диалогового обучения.

Работа проводится на учебных занятиях и во внеклассных объединениях учащихся по интересам.

Просим Вас внимательно прочитать предлагаемую анкету и высказать свои суждения по данной, на наш взгляд, актуальной научно-методической проблеме - «Формирование диалогических умений обучающихся».

Заранее благодарны за внимание и помощь в работе.

Уважаемый коллега!

1. Современная практика испытывает потребность в использовании оптимальных путей формирования диалогических умений, т.е. способности к диалоговому обучению. Согласны ли Вы с существованием данной проблемы?

а) Да согласен (согласна);

б) Нет не согласен (не согласна);

в) Затрудняюсь с ответом.

2. Применяете ли Вы в своей практике приемы формирования диалогического общения с обучающимися ?

а) да, применяю;

б) нет, не применяю ;

в) применяю, но иногда;

г) затрудняюсь с ответом;
3. Если Вы применяете, то какие стратегии и приемы, по вашему мнению, более приемлимы ?
а) духовный диалог;
б) смыслотворческий диалог;
в) рефлексивный диалог;
г) самореализующий диалог;
д) кумулятивная беседа;
е) исследовательская беседа;
ж) беседа - дебаты и т.д.

4. Считаете ли Вы необходимым дальнейший методический поиск оригинальных путей формирования диалогического умения учащихся 5-9 классов?
а) Да, считаю;
б) Нет,не считаю ;
в) Затрудняюсь с ответом

Еще раз благодарим за помощь в работе. 
Результаты опроса (анкетирования) учителей - предметников. (В \%\% и пересчете на 100 опрошенных)

\begin{tabular}{|c|c|c|}
\hline № & $\begin{array}{l}\text { Содержание ответов } \\
\text { на заданные вопросы: }\end{array}$ & Ответы в \%\%: \\
\hline 1. & $\begin{array}{l}\text { Считают, что современная } \\
\text { практика испытывает по- } \\
\text { требность в использовании } \\
\text { оптимальных путей фор- } \\
\text { мирования диалогических } \\
\text { умений, т.е. способности к } \\
\text { диалоговому обучению. }\end{array}$ & $\begin{array}{l}60 / 100 \\
30 / 100 \\
10 / 100\end{array}$ \\
\hline 2. & $\begin{array}{l}\text { Применяют в своей прак- } \\
\text { тике приемы формирования } \\
\text { диалогического общения с } \\
\text { обучающимися . }\end{array}$ & $\begin{array}{l}50 / 100 \\
20 / 100 \\
20 / 100 \\
10 / 100\end{array}$ \\
\hline 3. & $\begin{array}{l}\text { Какие стратегии и приемы, } \\
\text { по мнению коллег, более } \\
\text { приемлимы? }\end{array}$ & $\begin{array}{l}\text { духовный диалог } \\
20 / 100 \\
\text { смыслотворческий } \\
\text { диалог 04/100 } \\
\text { рефлексивный диалог } \\
30 / 100 \\
\text { самореализующий } \\
\text { диалог 10/100 } \\
\text { кумулятивная беседа } \\
\text { 06/100 } \\
\text { исследовательская беседа } \\
\text { 20/100 } \\
\text { беседа - дебаты 10/100 }\end{array}$ \\
\hline 4. & $\begin{array}{l}\text { Считают, что дальнейший } \\
\text { методический поиск ориги- } \\
\text { нальных путей формирова- } \\
\text { ния диалогического умения } \\
\text { необходим . }\end{array}$ & $\begin{array}{l}40 / 100 \\
30 / 100 \\
30 / 100\end{array}$ \\
\hline
\end{tabular}

114
Приложение №2.

Методические рекомендации для учителей предметников ( на курсах ШМУ) при использовании приема «Странник» для расширения информации и формирования языковой компетенции

Деятельность учителя по развитию языковых навыков в учебном процессе в условиях обновления содержания среднего образования - есть существенный объект пристального рассмотрения. обновленная программа школьного образования требует не передачу энциклопедической, застывшей информации,которая имеется в огромном количестве на бумажных и электронных носителях, в умении самостоятельно добывать знания .Для этого необходимо развивать и учебные, и коммуникативные навыки. Наряду с учебными навыками необходимо развивать коммуникативные навыки, необходимые для формирования языковой компетенции,для понимания этой проблемы, рекомендуем учителям русского языка провести для педагогического коллектива семинар-тренинг.

Для семинара-тренинга ( на курсах ШМУ) предлагаем разделить педагогический коллектив на четыре группы, каждая из которых получает маркер определенного цвета. Цель первого этапа -помочь в понимании важности всех языковых навыков. Для этого на четырех углах разместить плакаты с названием одного из коммуникативных навыков: слушание,говорение,чтение,письмо.

Ведущий объясняет задание. Все участники должны по 4 минуты постоять у плаката и записать ответ на вопрос: «Что дает человеку этот навык?».Группа работает у плаката,делает записи,обсуждает,затем переходит по 
навыком.

\begin{tabular}{|l|l|}
\hline $\begin{array}{l}\text { Слушание 1 группа. } \\
\text { Основной этап } \\
\text { восприятия на слух, } \\
\text { понимание информации, } \\
\text { раскодирование } \\
\text { и интерпретация } \\
\text { информации. } \\
\text { Получение информации. }\end{array}$ & $\begin{array}{l}\text { Рлушание 2 группа. } \\
\text { запаса. Усвоение } \\
\text { орфоэпических норм языка. }\end{array}$ \\
\hline $\begin{array}{l}\text { Слушание 3 группа. } \\
\text { Получение опыта. } \\
\text { Развитие памяти, } \\
\text { мышления. } \\
\text { Развитие воображения. } \\
\text { Побуждение к диалогу, } \\
\text { к теме разговора, } \\
\text { формулирование ответа. }\end{array}$ & $\begin{array}{l}\text { Слушание 4 группа. } \\
\text { Установка доверительных } \\
\text { отношений. } \\
\text { Эмпатия. Прогнозирование, } \\
\text { дальнейшее развитие } \\
\text { диалог. } \\
\text { онализ ситуаций } \\
\text { обен, культурном и и } \\
\text { снтеллектуальном уровне } \\
\text { своего собеседника. }\end{array}$ \\
\hline
\end{tabular}

У другого плаката можно ознакомиться с записями предыдущей группы, затем своим цветом расширить имеющуюся информацию .таким образом каждая группа имеет возможность поработать со всеми видами языковых навыков,понять их значение в жизни человека, дискутируя,дополнить и расширить имеющуюся информацию.
Психолого-педагогические рекомендации для учителей предметников при диалоговом обучении в учебном процессе для расширения информации и формирования языковой компетенции методом «Странник».

Прием расширения информации методом диалогового обучения «Странник» также эффективен в учебном процессе. приведем пример, 8 класс, предмет «русская литература» А.С.Пушкин. «Капитанская дочка»

Цель 8. АИ5 - характеризовать героев произведения, их поступки, мотивы поведения, значения имен и фамилий .

На партах лежат листы ватмана, где написаны имена героев произведения: Петр Андреевич Гринев, Алексей Иванович Швабрин, Мария Ивановна Миронова, Емельян Пугачев. Учащиеся в течение пяти минут обсуждают и записывают на ватмане все действия этого персонажа. После этого переходят ко второму ватману и,дискутируя и обсуждая правильность суждения, записывают все действия второго персонажа. После того как обучающиеся заполнили все листы, они возвращаются и видят, как другие группы расширили, дополнили их информацию о героях произведения. В своих дебатах с учениками рекомендуется обсудить сначала все, что написали они сами, а потом уже то, что дополнили их товарищи .

Мы хотим повторить, что диалог учит детей принимать информацию товарищей, сотрудничать. Также диалог, как психолого-педагогический подход, снимает момент соперничества. 
На следующем занятии необходимо дать дифференцированное задание на обсуждение и соотнесение.

\begin{tabular}{|l|l|l|}
\hline Петр & Действия и поступки. & Марья \\
Андреевич & Заблудился во время метели & Ивановна \\
Гринев & Дарит заячий тулуп & Миронова \\
& Ухаживает после дуэли & \\
Гоняет голубей & \\
Живет беззаботно & \\
Уезжает из дома служить & \\
Соблюдает наказ отца & \\
Пишет стихи, защищает честь & \\
& на дуэли \\
& Живет с родителями & \\
Едет к императрице & \\
& Предан императрице & \\
Просит о помиловании & \\
\hline
\end{tabular}

\begin{tabular}{|l|l|l|}
\hline Алексей & Действия и поступки & Петр \\
Иванович & Осужден за смертоубийство & Гндевич \\
Швабрин & Глужит в крепости & \\
& Любит Марью Миронову & \\
& Переходит на сторону восставших & \\
Грубит Савельичу & \\
& Встречает вожатого \\
& Держит в плену Машу & \\
Предает Отечество & \\
& Дает ложные показания \\
Преданно служит императрице & \\
& Соблюдает наказ отца & \\
& Защищает честь Маши на дуэли & \\
& Содержится под стражей & \\
& Присутствует на казни Пугачева & \\
\hline
\end{tabular}

\begin{tabular}{|l|l|l|}
\hline $\begin{array}{l}\text { Алексей } \\
\text { Иванович } \\
\text { Швабрин }\end{array}$ & $\begin{array}{l}\text { Емеиствия и поступки } \\
\text { Пугачев }\end{array}$ \\
& Встречается с Гриневым & \\
Выходит а дуэль с Гриневым & \\
Указывает путь заблудившимся & \\
в метели & \\
Служит в крепости & \\
Собирает войско & Сватается к Маше Мироновой \\
Говорит иносказательно & \\
Дает ложные показания & \\
Завоевывает крепость & \\
Проигрывает войну & \\
\end{tabular}

Таким образом прием на обсуждение и расширение информации «Странник» способствует развитию у учеников качеств характерных для навыков 21 века (сотрудничество,коммуникация, взаимопомощь), повышает внутреннюю мотивацию, демонстрирует учащимся значимость мнения других в понимании изучаемой проблемы. Задания на обсуждение и соотнесение способствуют более полному пониманию темы, поступков героев, развивают навыки говорения, а именно повествования, аргументирования, сравнения и сопоставления с поступками другого персонажа. 


\section{Приложение №4.}

Приведён пример примерных учебных планов по предмету "Русская классическая литература", направленных на формирование читательской грамотности, речевой компетенции, посредством диалогового обучения.

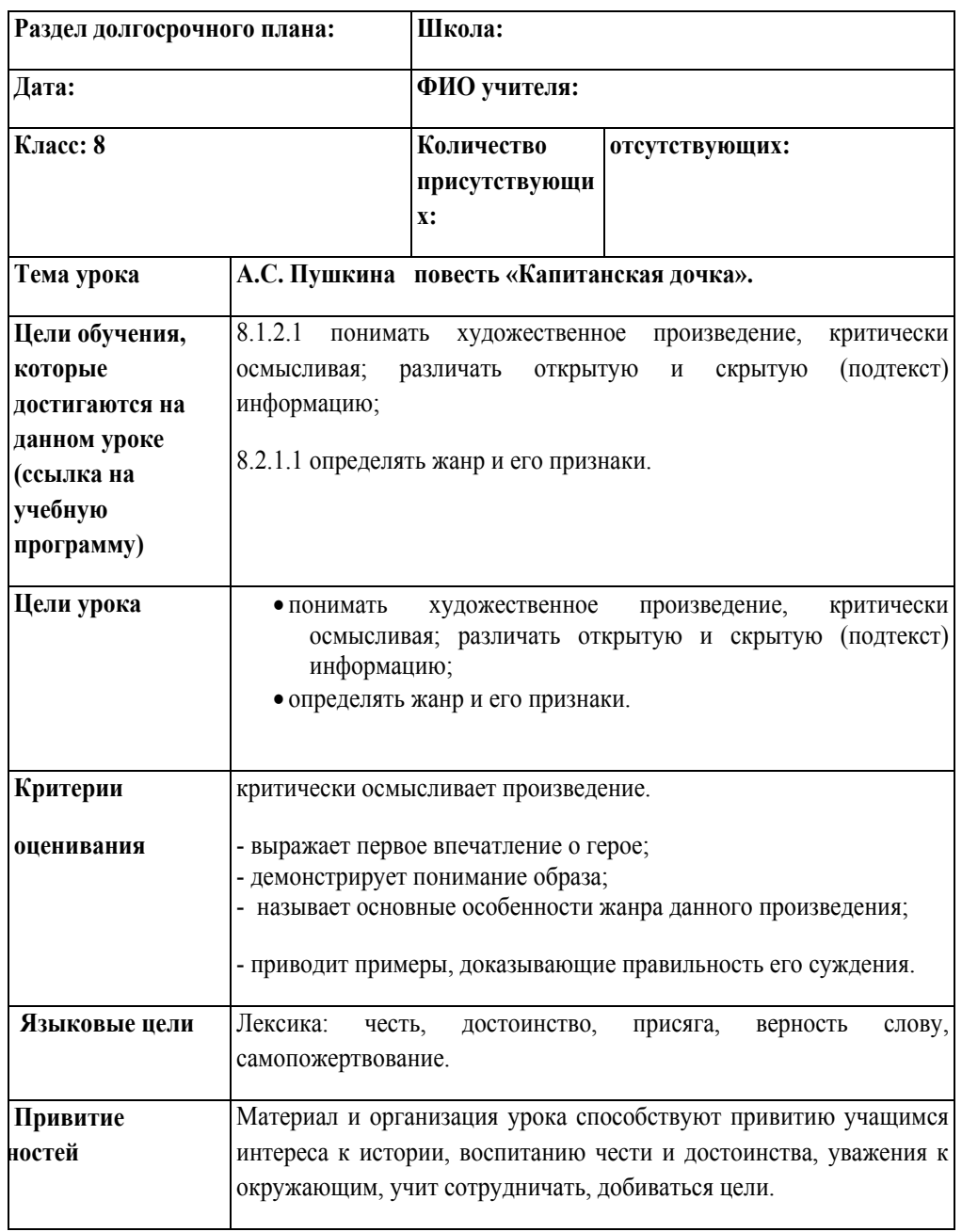

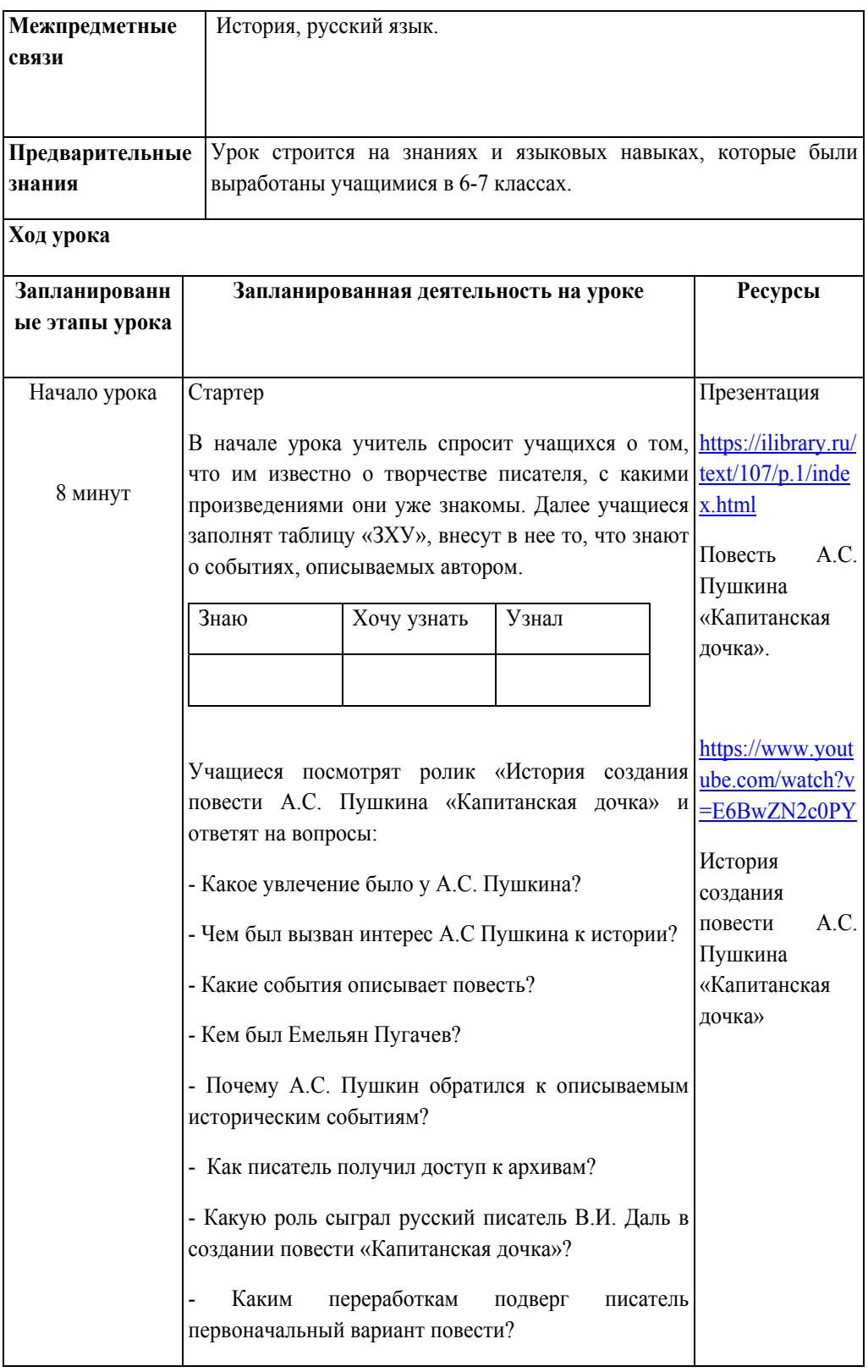




\begin{tabular}{|c|c|}
\hline & К, Ф - короткая обратная связь \\
\hline Середина урока & 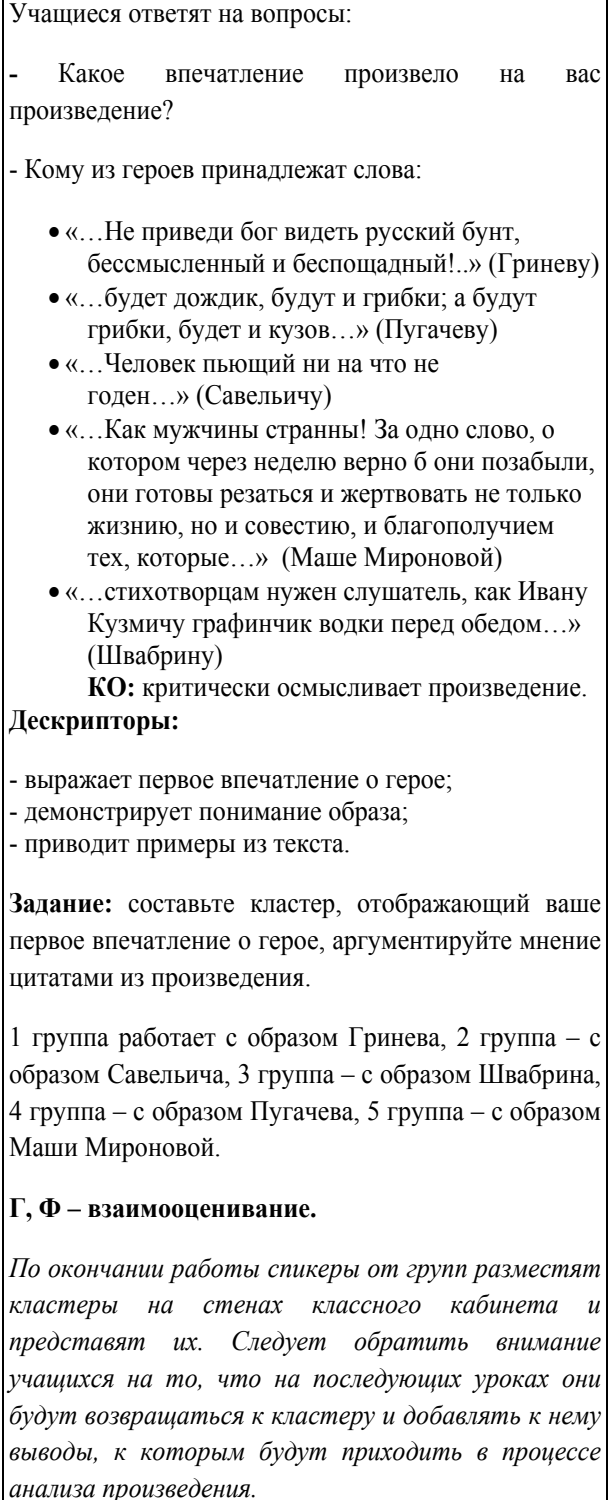 \\
\hline
\end{tabular}

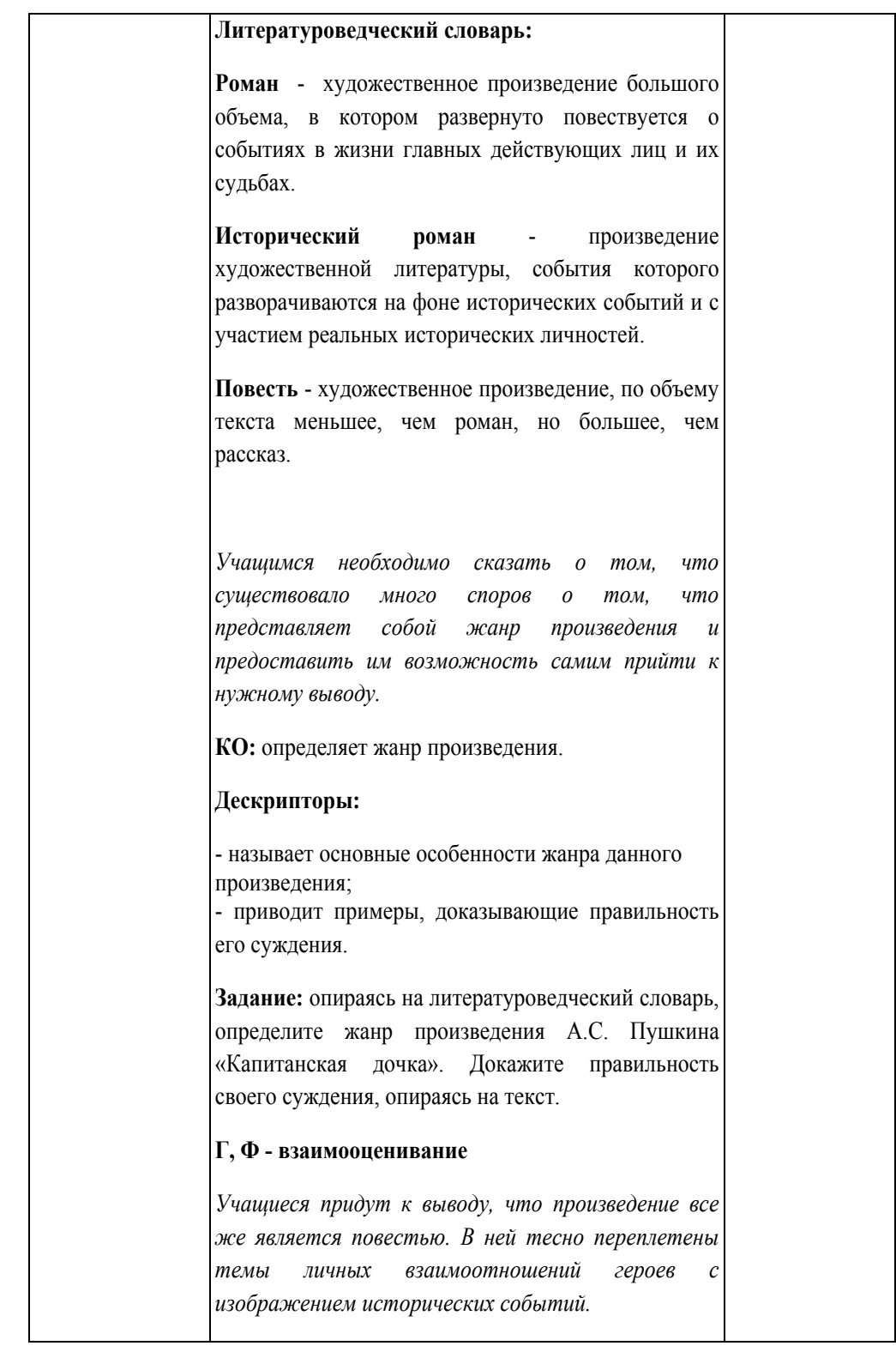




\begin{tabular}{|c|c|c|c|}
\hline \multirow[t]{3}{*}{2 минут } & \multicolumn{3}{|c|}{$\begin{array}{l}\text { Рефлексия } \\
\text { Учащиеся вернутся к таблице «ЗХХ», которую } \\
\text { заполняли в начале урока, и заполнят третью } \\
\text { колонку «Что узнал на уроке». }\end{array}$} \\
\hline & Знаю & Хочу узнать & Узнал \\
\hline & & & \\
\hline
\end{tabular}

Лирика поэтов XIX века.

\begin{tabular}{|c|c|c|c|}
\hline \multicolumn{2}{|c|}{$\begin{array}{l}\text { Раздел долгосрочного п плана: } \\
\text { Любовь и честь. }\end{array}$} & \multicolumn{2}{|l|}{ Школа: } \\
\hline \multicolumn{2}{|l|}{ Дата: } & \multicolumn{2}{|l|}{ ФИО учителя: } \\
\hline \multicolumn{2}{|l|}{ Класс: 8} & $\begin{array}{l}\text { Количество } \\
\text { присутствующ } \\
\text { их: }\end{array}$ & отсутствующих: \\
\hline Тема урока & \multicolumn{3}{|c|}{ Лирика поэтов XIX века. } \\
\hline \begin{tabular}{lr} 
Цели & \multicolumn{1}{c}{ обучения, } \\
которые & \\
достигаются & на \\
данном & уроке \\
(ссылка & на \\
учебную & \\
программу) & \\
\end{tabular} & $\begin{array}{l}8.1 .2 .1 \text { поним } \\
\text { осмысливая; } \\
\text { информацию; } \\
8.1 .3 .1 \text { самосто } \\
\text { наизусть цитат }\end{array}$ & $\begin{array}{l}\text { ать художествен } \\
\text { различать открь } \\
\text { ятельно находить } \\
\text { I, фрагменты, отра }\end{array}$ & $\begin{array}{l}\text { ное произведение, критически } \\
\text { тую и скрытую (подтекст) } \\
\text { в тексте и выразительно читать } \\
\text { жающие тематику произведения }\end{array}$ \\
\hline Цели урока & $\begin{array}{r}\text { - понимать } \\
\text { осмыслг } \\
\text { информ } \\
\text { - самостоят } \\
\text { наизусті } \\
\text { произве }\end{array}$ & $\begin{array}{l}\text { художественно } \\
\text { ивая; различать о } \\
\text { ацию; } \\
\text { ельно находить в } \\
\text { ц цитаты, фраг } \\
\text { дения }\end{array}$ & $\begin{array}{l}\text { произведение, критически } \\
\text { крытую и скрытую (подтекст) } \\
\text { тексте и выразительно читать } \\
\text { ленты, отражающие тематику }\end{array}$ \\
\hline $\begin{array}{l}\text { Критерии } \\
\text { оценивания }\end{array}$ & $\begin{array}{l}\text { понимает и кр } \\
\text { - понимает тем } \\
-\quad \text { раскрывае } \\
\text { информация); } \\
\text { - пишет к } \\
\text { стихотворения. } \\
\text { читает вырази } \\
\text { со слушателям } \\
\text { - соблюдает ор } \\
\text { - передает с }\end{array}$ & $\begin{array}{l}\text { итически осмысли } \\
\text { у стихотворения (с } \\
\text { т смысл стІ } \\
\text { омментарий, де } \\
\text { гельно стихотворе } \\
\text { и; } \\
\text { фоэпические норм } \\
\text { мысл прочитаннс }\end{array}$ & $\begin{array}{l}\text { ает лирическое произведение. } \\
\text { гкрытая информация); } \\
\text { хотворения } \\
\text { оподразумеваемая } \\
\text { оостируя понимание темы } \\
\text { лие, проявляя активное общение } \\
\text { I при чтении; } \\
\text { о отрывка, делая логическое }\end{array}$ \\
\hline
\end{tabular}

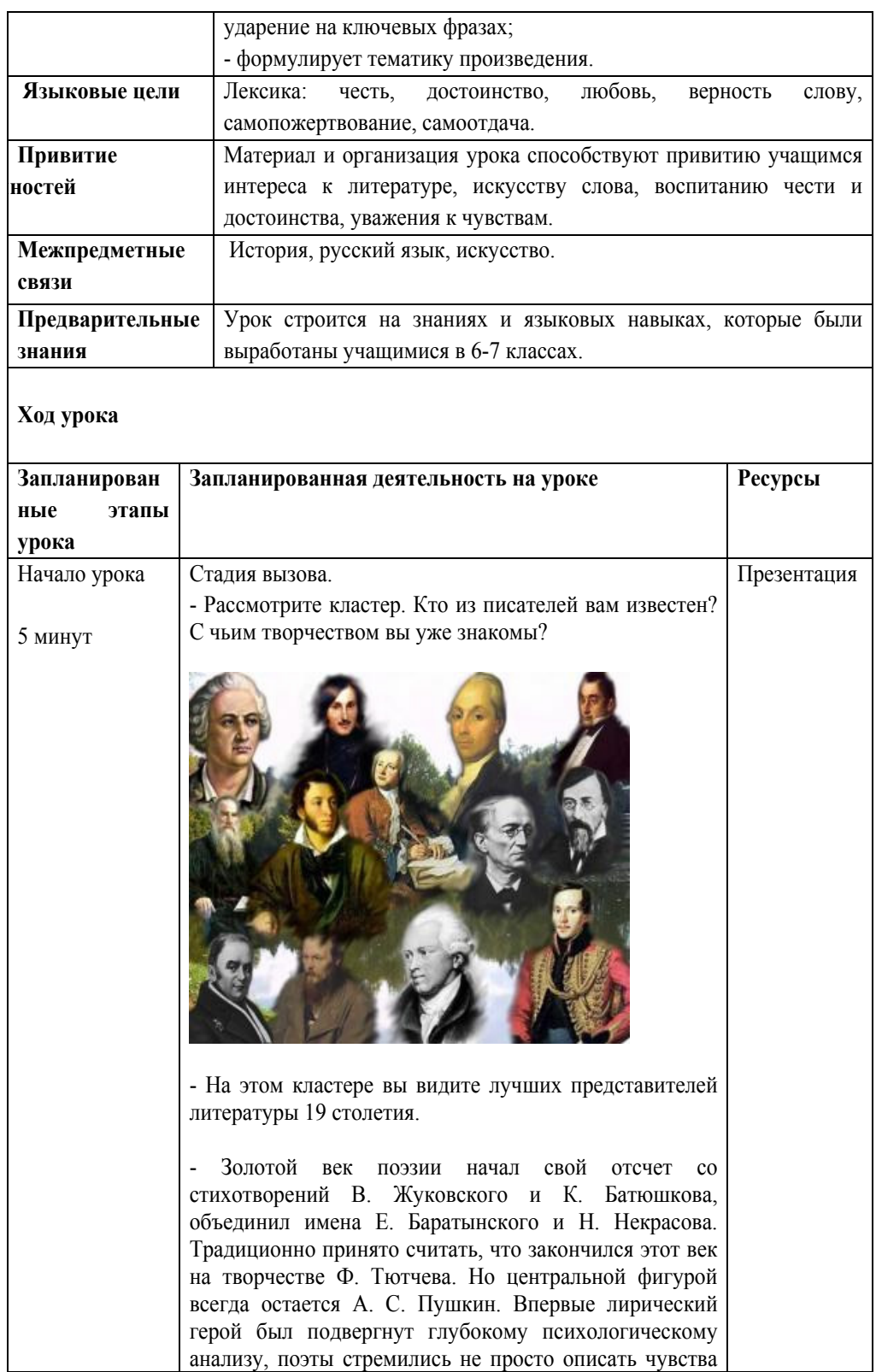




\begin{tabular}{|c|c|c|}
\hline & \multicolumn{2}{|c|}{$\begin{array}{l}\text { своего героя, а буквально, обнажить душу. } \\
\text { - Сегодня мы поговорим об особенностях лирики } 19 \\
\text { века, а на следующих уроках подробно проанализируем } \\
\text { творчество самых ярких ее представителей. }\end{array}$} \\
\hline $\begin{array}{l}\text { Середина урока } \\
33 \text { минут }\end{array}$ & \multicolumn{2}{|c|}{$\begin{array}{l}\text { Словарная работа: } \\
\text { Золотой век русской литературы - крылатое } \\
\text { выражение, которым называют русскую литературу } \\
\text { ХІХ века. } \\
\text { Золотым веком русской поэзии называют первую } \\
\text { треть ХІХ века. } \\
\text { 8.1.2.1 } \\
\text { кО: понимает и критически осмысливает лирическое } \\
\text { произведение. } \\
\text { Дескрипторы: } \\
\text { - понимает тему стихотворения (открытая } \\
\text { информация); } \\
\text { - раскрывает смысл стихотворения (подразумеваемая } \\
\text { информация); } \\
\text { - пишет комментарий, демонстрируя понимание темы } \\
\text { стихотворения. } \\
\text { Задание: прочитайте выразительно стихотворение, } \\
\text { напишите комментарий, указав тему стихотворения, } \\
\text { открытую и скрытую информацию. }\end{array}$} \\
\hline & \begin{tabular}{|l}
1 группа \\
Евгений Баратынский \\
К жесттокой \\
\\
Неизвинительной \\
ошибкой, \\
Скажите, долго ль \\
будет вам \\
Внимать с холодною \\
улыбкой \\
Любви укорам и \\
мольбам? \\
Одни победы вам \\
известны; \\
Любовь нечаянно
\end{tabular} & \begin{tabular}{|l|}
2 группа \\
Василий Жуковский \\
Мой друг, хранитель-ангел \\
мой \\
Мой друг, хранитель- \\
ангел мой, \\
О ты, с которой нет сравненья, \\
Люблю тебя, дышу тобой; \\
Но где для страсти \\
выраженья? \\
Во всех природы красотах \\
Твой образ милый я встречаю; \\
Прелестных вижу - в их \\
\end{tabular} \\
\hline
\end{tabular}

\begin{tabular}{|c|c|}
\hline $\begin{array}{l}\text { узнав, } \\
\text { Каких лишитеся вы } \\
\text { прав } \\
\text { И меньше ль будете } \\
\text { прелестны? } \\
\text { Ко мне, примерно, } \\
\text { нежной став, } \\
\text { Вы наслажденья } \\
\text { лишены ли } \\
\text { Дурачить пленников } \\
\text { других } \\
\text { И гордой быть, как } \\
\text { прежде были, } \\
\text { К толпе соперников } \\
\text { моих? } \\
\text { Еще же нужно } \\
\text { размышленье! } \\
\text { Любви простое } \\
\text { упоенье } \\
\text { Вас не довольствует } \\
\text { вполне; } \\
\text { Но с упоеньем } \\
\text { поклоненье } \\
\text { Соединить не трудно } \\
\text { мне; } \\
\text { И, ваш угодник } \\
\text { постоянный, } \\
\text { Попеременно я бы мог } \\
\text { - } \\
\text { Быть с вами запросто } \\
\text { в диванной, } \\
\text { В гостиной быть у } \\
\text { ваших ног. }\end{array}$ & \begin{tabular}{|l} 
чертах \\
Одну тебя воображаю. \\
Беру перо - им начертать \\
Могу лишь имя незабвенной; \\
Одну тебя лишь прославлять \\
Могу на лире восхищенной: \\
С тобой, один, вблизи, вдали, \\
Тебя любить - одна мне \\
радость; \\
Ты мне все блага на земли; \\
Ты сердцу жизнь, ты жизни \\
сладость. \\
В пустыне, в шуме в \\
городском \\
Одной тебе внимать мечтаю; \\
Твой образ - забываясь сном, \\
С последнй мыслию сливаю; \\
Приятный звук твоих речей \\
Со мной во сне не расстается; \\
Проснусь - и ты в душе моей \\
Скорей, чем день очам \\
коснется. \\
Ах! мне ль разлуку знать с \\
тобой? \\
Ты всюду спутник мой \\
незримый; \\
Молчишь - мне взор понятен \\
твой, \\
Для всех других \\
неизьяснимый; \\
Я в сердце твой приемлю глас;; \\
Я пью любовь в твоем \\
дыханье... \\
Восторги, кто постигнет вас, \\
Тебя, души очарованье? Тобой
\end{tabular} \\
\hline
\end{tabular}




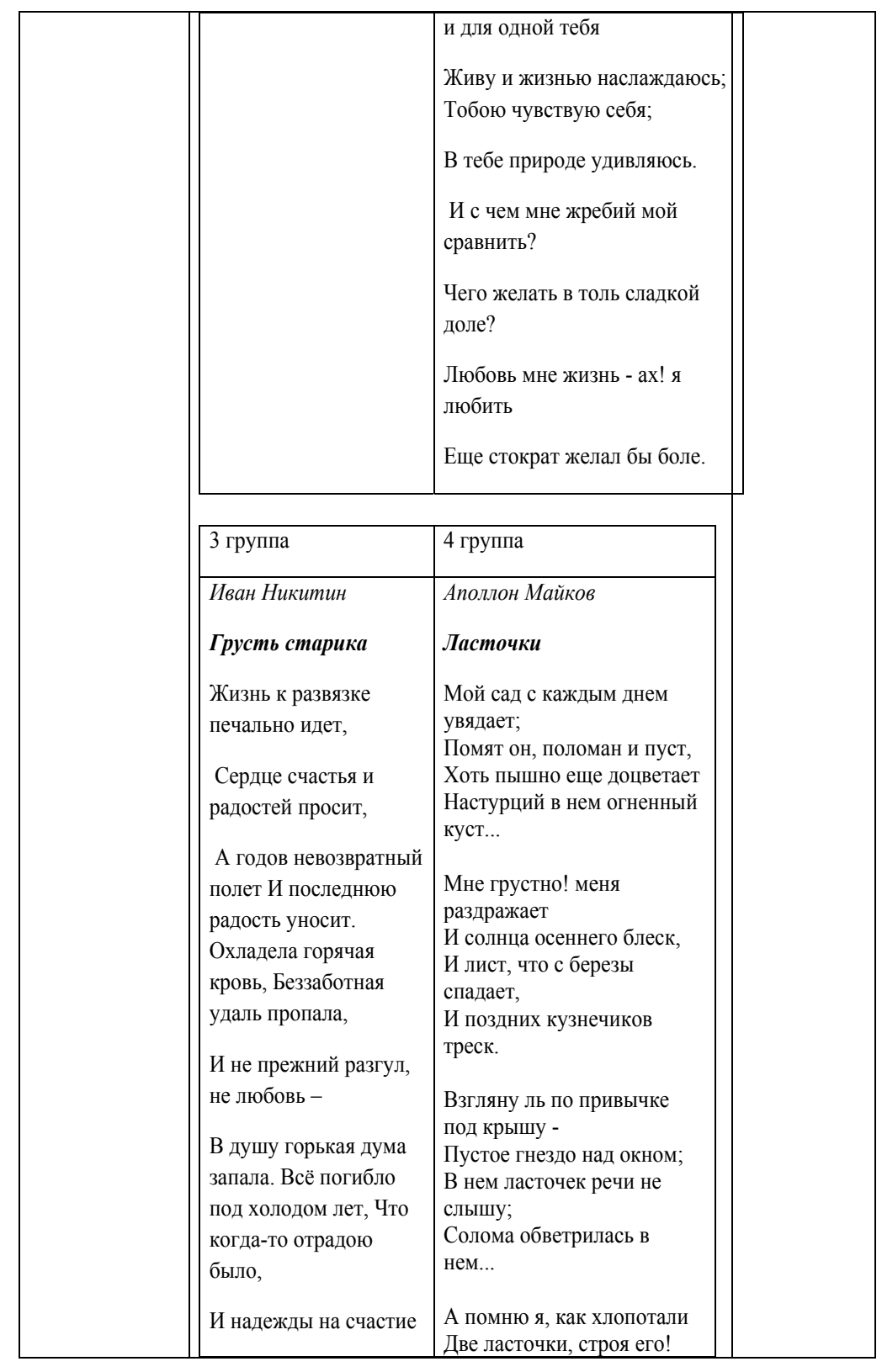

\begin{tabular}{|c|c|}
\hline \begin{tabular}{|l} 
нет, \\
И в природе всё стало \\
уныло: Лес, \\
нахмурясь, как слабый \\
старик, \\
Погруженный в \\
тяжелую думу, \\
Головою кудрявой \\
поник, Будто тужит о \\
чем-то угрюмо; Ветер \\
с тучею, с синей \\
волной Речь сердитую \\
часто заводит; \\
Бледный месяц над \\
сонной рекой, \\
Одинокий, задумчиво \\
бродит... \\
В годы прежние мир \\
был иной: \\
Как невеста, земля \\
убиралась, Что \\
камыш, хлеб стоял \\
золотой, \\
Степь зеленым \\
ковром расстилалась, \\
Лес приветно под тень \\
свою звал, \\
Ветер весело пел в \\
чистом поле, \\
По ночам ярко месяц \\
сиял, Реки шумно \\
катилися в море. И, \\
как пир, жизнь \\
привольная шла, \\
Душа воли, простора \\
просила, Под грозою
\end{tabular} & $\begin{array}{l}\text { Как прутики глиной } \\
\text { скрепляли } \\
\text { И пуху таскали в него!.. } \\
\text { Как весел был труд их, как } \\
\text { ловок! } \\
\text { Как любо им было, когда } \\
\text { Пять маленьких, быстрых } \\
\text { головок } \\
\text { Выглядывать стали с } \\
\text { гнезда! } \\
\text { И целый-то день } \\
\text { говоруньи, } \\
\text { Как дети, вели разговор... } \\
\text { Потом полетели, летуньи! } \\
\text { Я мало их видел с тех пор! } \\
\text { И вот - их гнездо одиноко! } \\
\text { Они уж в иной стороне - } \\
\text { Далеко, далеко, далеко... } \\
\text { О, если бы крылья и мне! }\end{array}$ \\
\hline
\end{tabular}




\begin{tabular}{|c|}
\hline 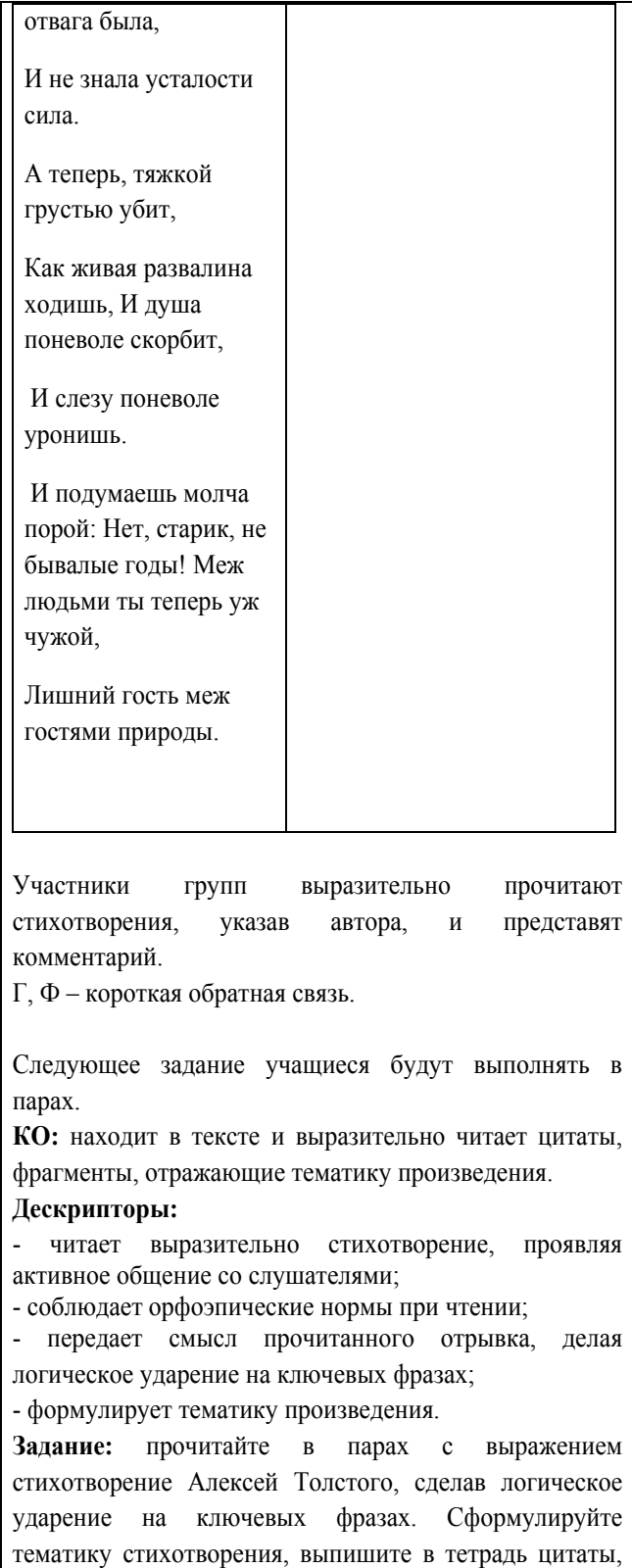 \\
\hline
\end{tabular}

\begin{tabular}{|c|c|}
\hline & $\begin{array}{l}\text { подтверждающие ваше мнение. } \\
\text { Алексей Толстой } \\
\text { Коль любить, так без рассудку... } \\
\text { Коль любить, так без рассудку, } \\
\text { Коль грозить, так не на шутку, } \\
\text { Коль ругнуть, так сгоряча, } \\
\text { Коль рубнуть, так уж сплеча! } \\
\text { Коли спорить, так уж смело, } \\
\text { Коль карать, так уж за дело, } \\
\text { Коль простить, так всей душой, } \\
\text { Коли пир, так пир горой! } \\
\text { (1854) } \\
\text { П, Ф - взаимооценивание } \\
\text { - Итак, в чем особенность поэзии первой трети } 19 \text { века? } \\
- \text { Назовите представителей мира литературы эой } \\
\text { эпохи. } \\
\text { к,Ф }\end{array}$ \\
\hline $\begin{array}{l}\text { Конец урока } \\
2 \text { минут }\end{array}$ & $\begin{array}{l}\text { Рефлексия «Цветовой индекс». } \\
\text { Каждому ученику необходимо предложить по } 3 \\
\text { карточки красного, желтого, зеленого цвета. Карточка } \\
\text { красного цвета обозначает: «Я удовлетворен уроком, } \\
\text { урок был полезен для меня! я получил заслуженную } \\
\text { оценку!». Желтый цвет - «Урок был в определенной } \\
\text { степени полезен для меня». Зеленый цвет - «Пользы от } \\
\text { урока я получил мало, не очень понимал, о чем идет } \\
\text { речь». } \\
\text { Домашнее задание: } \\
\text { Найти интересные факты об А.С. Пушкине. }\end{array}$ \\
\hline
\end{tabular}




\begin{tabular}{|c|c|c|c|}
\hline \multicolumn{2}{|c|}{$\begin{array}{l}\text { Раздел долгосрочного п плана: } \\
\text { Любовь и честь. }\end{array}$} & \multicolumn{2}{|l|}{ Школа: } \\
\hline \multicolumn{2}{|l|}{ Дата: } & \multicolumn{2}{|l|}{ ФИО учителя: } \\
\hline \multicolumn{2}{|l|}{ Класс: 8} & $\begin{array}{l}\text { Количество } \\
\text { присутствую- } \\
\text { щих: }\end{array}$ & отсутствующих: \\
\hline $\begin{array}{l}\text { Тема } \\
\text { урока }\end{array}$ & \multicolumn{3}{|c|}{$\begin{array}{l}\text { А.С. Пушкина. } \\
\text { Я помню чудное мгновенье }\end{array}$} \\
\hline $\begin{array}{lr}\text { Цели } & \text { обучения, } \\
\text { которые } & \\
\text { достигаются } & \text { на } \\
\text { данном } & \text { уроке } \\
\text { (ссылка } & \text { на } \\
\text { учебную } & \\
\text { программу) }\end{array}$ & \multicolumn{3}{|c|}{$\begin{array}{l}\text { 8.2.3.1 выделять в тексте произведения элементы композиции, } \\
\text { объяснять значение вставных эпизодов; } \\
\text { 8.2.1.1 определять жанр и его признаки (трагедия, комедия, поэма). }\end{array}$} \\
\hline Цели урока & \multicolumn{3}{|c|}{$\begin{array}{l}\text { понять сложность переживаний, богатство чувств поэта, } \\
\text { совершенствование навыков выразительного чтения. }\end{array}$} \\
\hline \begin{tabular}{|l|} 
Критерии \\
оценивания
\end{tabular} & \multicolumn{3}{|c|}{$\begin{array}{l}\text { выделяет в тексте произведения элементы композиции. } \\
\text { - находит фрагмент, который является завязкой произведения; } \\
\text { - определяет событие, являющееся развитием действия } \\
\text { произведения; } \\
\text { - определяет кульминацию произведения; } \\
\text { - находит развязку произведения; } \\
\text { - делает выводы об особенностях композиции стихотворения. } \\
\text { - называет основные особенности жанра данного произведения; } \\
\text { - приводит примеры, доказывающие правильность его суждения. }\end{array}$} \\
\hline Языковые цели & \multicolumn{3}{|c|}{$\begin{array}{l}\text { Лексика: честь, достоинство, любовь, } \\
\text { самопожертвование, самоотдача. }\end{array}$} \\
\hline $\begin{array}{l}\text { Привитие } \\
\text { ностей }\end{array}$ & \multicolumn{3}{|c|}{$\begin{array}{l}\text { Материал и организация урока способствуют привитию учащимся } \\
\text { интереса к литературе, искусству слова, воспитанию чести и } \\
\text { достоинства, уважения к чувствам. }\end{array}$} \\
\hline $\begin{array}{l}\text { Межпредметные } \\
\text { связи }\end{array}$ & \multicolumn{3}{|c|}{ История, русский язык, искусство. } \\
\hline $\begin{array}{l}\text { Предварительные } \\
\text { знания }\end{array}$ & \multicolumn{3}{|c|}{$\begin{array}{l}\text { Урок строится на знаниях и языковых навыках, которые были } \\
\text { выработаны учащимися в 6-7 классах. }\end{array}$} \\
\hline
\end{tabular}

\begin{tabular}{|c|c|c|}
\hline \multicolumn{3}{|l|}{ Ход урока } \\
\hline $\begin{array}{l}\text { Запланиро } \\
\text { ванные } \\
\text { этапы } \\
\text { урока }\end{array}$ & Запланированная деятельность на уроке & Ресурсы \\
\hline $\begin{array}{l}\text { Начало } \\
\text { урока } \\
8 \text { минут }\end{array}$ & $\begin{array}{l}\text { Стадия вызова. } \\
\text { - С какими произведениями А.С. Пушкина вы уже } \\
\text { знакомы? } \\
\text { - Что вам известно о личности писателя и его творчестве? } \\
\text {-Какие художественные средства вы встреечали в } \\
\text { произведениях А.С.Пушкина. } \\
\text { ( «Одухотворенность, чистота, чувство любви в лиике } \\
\text { А.С. Пушикина») } \\
\text { После просмотра учащиеся ответят на вопросы: } \\
\text { - Как поэт рассматривал любовь? Чем она была для него? } \\
\text { - Кому адресует поэт свои стихотворения? } \\
\text { - В чем особенность любовной лирики поэта? } \\
\text { - Назовите стихотворения о любви А.С. Пушкина. } \\
\text { К, Ф }\end{array}$ & \\
\hline $\begin{array}{l}\text { Середина } \\
\text { урока } \\
30 \text { минут }\end{array}$ & $\begin{array}{l}\text { Далее учителю необходимо рассказать учащиимся } \\
\text { историю создания стихотворения «Я помню чудное } \\
\text { мгновенье». } \\
\text { Учащиеся прослушают стихотворение и ответят на } \\
\text { вопросы: } \\
\text { - Можно ли считать стихотворение «Я помню чудное } \\
\text { мгновенье» автобиографичным? } \\
\text { - Определите тему стихотворения. Можно ли, читая } \\
\text { стихотворение, увидеть события, которые переживает } \\
\text { лирический герой? } \\
\text { Для Пушкина любовь - одно из самых сильных } \\
\text { человеческих чувств и самое естественное проявление } \\
\text { человеческих отношений . Любовь овладевает всем } \\
\text { существом человека, и } \\
\text { все его внутренние силы приходят в движение. } \\
\text { Слово «любовь» на всех языках мира понятно без } \\
\text { перевода. Чувство любви самое поэтическое - } \\
\text { возвышенное, чистое, прекрасное. Тема любви } \\
\text { неисчерпаема в литературе, музыке, искусстве. Она }\end{array}$ & $\begin{array}{l}\text { Стихотворение } \\
\text { «Я помню } \\
\text { чудное } \\
\text { мгновенье» в } \\
\text { исполнении } \\
\text { учителя }\end{array}$ \\
\hline
\end{tabular}




\begin{tabular}{|c|}
\hline $\begin{array}{l}\text { всегда нова и неповторима для каждого приходящего в } \\
\text { этот мир . } \\
\text { Великий английский поэт Вильям Шекспир писал: » } \\
\text { Любовь-блеск солнечный, дождю идущий вслед. Любовь } \\
\text { всегда свежа, как яркий вешний цвет».Эти слова мы } \\
\text { взяли эпиграфом к нашему уроку . Сегодня мы говорим о } \\
\text { теме любви в творчестве А. С. Пушкина. Давайте } \\
\text { вспомним героиню, которую он боготворил, которую } \\
\text { называл «милым идеалом». } \\
\text { Душевная чистота, благородство -вот что в первую } \\
\text { очередь отличает пушкинскую Татьяну. } \\
\text { нсценировка } 3 \text { главы романа «Евгений Онегин». } \\
\text { 3)Учитель Любовь бывает разной: счастливой или } \\
\text { несчастной, взаимной или безответной...Но какая бы она } \\
\text { ни была, любовь всегда пробуждала в душе Пушкина } \\
\text { творческую энергию . } \\
\text { ученик в роли ПУШКИНА. } \\
\text { - Помню, как в моей жизни появилась очаровательная } \\
\text { Анна Петровна Керн. Анна Петровна отличалась редким } \\
\text { женским обаянием, живостью ума, образованностью, } \\
\text { широтою интересов. Эта женщина оставила заметный } \\
\text { след не только в моей поэзии, но и в моей жизни. } \\
\text { Ученица в роли А.П.Керн. } \\
\text { Я воспитывалась в Тверской губернии вместе с моей } \\
\text { двоюродной сестрой Анной Николаевной Вульф. В } 16 \\
\text { лет меня выдали замуж за генерала Керна. Вместе со } \\
\text { своими родственниками я часто бывала в доме } \\
\text { Олениных. На одном из вечеров у них я встретила } \\
\text { Пушкина, но поначалу не заметила его .Но вскоре он дал } \\
\text { себя заметить . Мне выпала роль Клеопатры, я держала } \\
\text { корзину с цветами .Пушкин подошёл, посмотрел на } \\
\text { корзину с цветами и сказал: «Можно ли быть такой } \\
\text { хорошенькой!» Вскоре вечер кончился и все стали } \\
\text { разъезжаться. Брат сел со мной в экипаж, Пуушкин } \\
\text { стоял на крыльце и провожал меня глазами. Очень } \\
\text { может быть, что именно об этой нашей встрече он } \\
\text { вспоминал потом в стихотворении «Я помню чудное } \\
\text { мгновенье». } \\
\text { Чтение учеником стихотворения « Я помню чудное } \\
\text { мгновенье» } \\
\text { Учитель. Керн казалась Пушкину « гением чистой } \\
\text { красоты» с «голосом нежным » и небесными чертами». } \\
\text { «Шли годы. Бурь порыв мятежный рассеял прежние }\end{array}$ \\
\hline
\end{tabular}

мечты». И вот через 5-6 лет, живя в Михайловском, и как-то посетив Тригорское, Пушкин вновь встретился с Анной. Вновь вспыхнуло забытое чувство. Оно принесло с собой « и божество, и вдохновенье, и жизнь, и слёзы, и любовь» и, конечно, знаменитое послание. «Я помню чудное мгновенье» лишь вызвано к жизни встречей с

А.П.Керн, но посвящено не ей, а пробуждению души

поэта, стремлению её к творчеству, к чему- то высшему и безмерному.

Через много лет - так распорядилась судьба - великий композитор Глинка увлёкся дочерью Анны Керн -

Екатериной. В свою очередь принёс дар на алтарь семьи Керн - знаменитый романс на стихи Пушкина «Я помню чудное мгновение». Восторжённый гимн торжествующей любви.

7 Слушание в г/записи романса

Учитель: На протяжении всей творческой биографии Пушкина (московский период, Болдинская осень,

Петербург) любовная лирика занимала огромное место.

Чтение учеником стихотворения «Я вас любил ».

2 ученик

Чувство любви в этой стихотворении тревожно, любовь ещё не остыла, она ещё живёт. Светлая печаль вызвана безответным чувством. Поэт вновь и вновь повторяет: «Я вас любил...». Он раскрывает перед любимой, как была сильна его любовь. В этой стихотворении чувство любви подчиняется чувству самоотверженности. Поэт сознательно побеждает чувство любви, потому что ему дорог покой любимой женщины. Он желает любимой женщине счастья. Учитель.

Всего 8 строчек! Но это целый мир душевной чистоты и благородства. Сколько в них мужской сдержанности и бескорыстия ! Да, любовь бывает разной: счастливой или несчастной, частной, взаимной или безответной...Но какая бы она ни была, любовь всегда пробуждала в душе Пушкина творческую энергию. В жизни Пушкина было много женщин: Е.Бакунина, Е. Воронцова.. Особое место в жизни Пушкина занимает Наталья Николаевна Гончарова.

На исходе 1828 году на балу, как вспоминает танцмейстер Иогель, Пушкин увидел юную красавицу. 


\begin{tabular}{|c|}
\hline $\begin{array}{l}\text { Чтение учеником воспоминаний И. Иогеля. } \\
\text { «Ей только минуло } 16 \text { лет, когда они впервые } \\
\text { встретились на балу в Москве. В белом воздушном } \\
\text { платье, с золотым обручем на голове, она в этот } \\
\text { знаменательный вечер поражала всех своей классической } \\
\text { царственной красотой . Александр Сергеевич не мог } \\
\text { оторвать от неё глаз, испытав на себе натиск чувства, } \\
\text { окрещенного любовью с первого взгляда...» Звали } \\
\text { девушку Наталья Николаевна, Натали. И впервые в } \\
\text { жизни, по его признанию, Александр Сергеевич был } \\
\text { робок. Вскоре он сделал предложение. В ответ получил } \\
\text { полуотказ - полусогласие. Но Пушкин не отступил: мечта } \\
\text { о счастье с этой девушкой кружила ему голову. } \\
\text { Ученик в роли Пушкина. } \\
\text { « Как было переполнено с счастьем моё сердце, когда } \\
\text { Наталья Гончарова согласилась стать моей женой. Да, } \\
\text { поначалу я любил её красоту, но, узнав её ближе, } \\
\text { полюбил } \\
\text { её душу. «Мадонна»- назвал я стихотворение, } \\
\text { обращённое к ней.» } \\
\text { Чтение учеником стихотворения «Мадонна» А. С. } \\
\text { Пушкина. } \\
\text { Ученица в роле Н. Пушкиной (Гончаровой). } \\
\text { «Пушкин познакомился со мной на одном из Московских } \\
\text { балов. Мне было иногда } 16 \text { лет. Не сразу я ответила на } \\
\text { его чувство. Однако страсть Пушкина преодолела все } \\
\text { преграды... После свадьбы мы переехали сперва в } \\
\text { Петербург, а потом на всё лето в Царское Село, эти } \\
\text { месяцы были самыми безоблачными в нашей жизни. И } \\
\text { эта безоблачность зафиксирована в творчестве } \\
\text { Пушкина... } \\
\text { Письмо Онегина к Татьяне удивительно достоверное по } \\
\text { силе выражения любовной страсти. Пушкин работает над } \\
\text { «Дубровским», романом, где опять- таки во весь голос } \\
\text { говорят любовные страсти. } \\
\text { Очень тяжело я пережила его смерть. Сразу после } \\
\text { похорон Пушкина я с детьми уехала в деревню. И } 7 \text { лет } \\
\text { жила в одиночестве. Я жила для детей и ради детей. } 4 \text { их } \\
\text { было у меня от Пушкина. Все они выросли достойными, } \\
\text { честными людьми.» } \\
\text { Учитель Натали... Её обвиняюо - и оправдают, } \\
\text { упрекают - и защищают, ищут в ней то погубительницу, } \\
\text { то Ангела - хранителя. Где можно найти истину о }\end{array}$ \\
\hline
\end{tabular}

жене поэта. В его письмах

а)Чтение отрывков из писем Пушкина. «С

твоим лицом ничего нельзя сравнить на свете - а душу твою люблю ещё более твоего лица (21

августа 1833)

б)« Я женат - и счастлив; одно желание моё, чтоб ничего

в жизни моей не изменилось - лучшего не дождусь» (

Пушкин - Плетневу. 24 февраля 2831 г.)

За 6 лет, которые они прожили вместе, четверо детей,

семья, дом. Перед смертью он сказал: « Жена моя-

ангел».

Чтение учеником стихотворения Н. Доризо »

Наталья Пушкина»

Как девочка, тонка, бледна,

Едва достигнув совершенства,

В день свадьбы знала ли она,

Что вышла замуж за бессмертье,

Что сохранится на века

Там, за супружеским порогом,

Все то, к чему её рука

В быту коснётся ненароком.

И даже строки письмеца,

Что он писал, о ней вздыхая,

Похитит из её ларца

Его вдова,

Вдова другая

Непогрешимая вдова-

Святая пушкинская слава

КО: выделяет в тексте произведения элементы композиции.

Дескрипторы:

- находит фрагмент, который является завязкой произведения;

- определяет событие, являющееся развитием действия произведения;

- определяет кульминацию произведения;

- находит развязку произведения;

- делает выводы об особенностях композиции стихотворения.

Задание:

Определите композицию стихотворения «Я помню чудное мгновенье...». Выделите в нем элементы сюжетной композиции - завязку, развитие действия, кульминацию и развязку. 


\begin{tabular}{|c|}
\hline 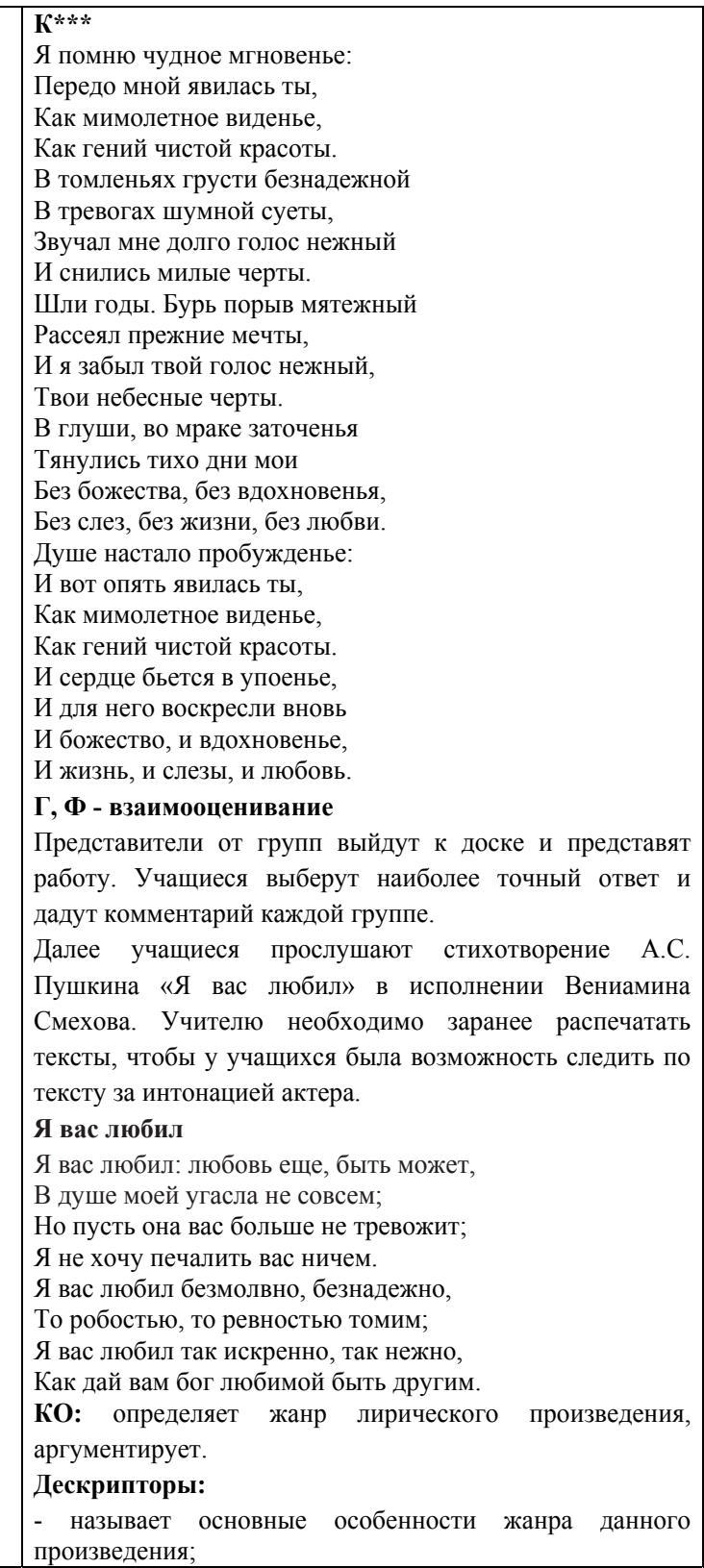 \\
\hline
\end{tabular}

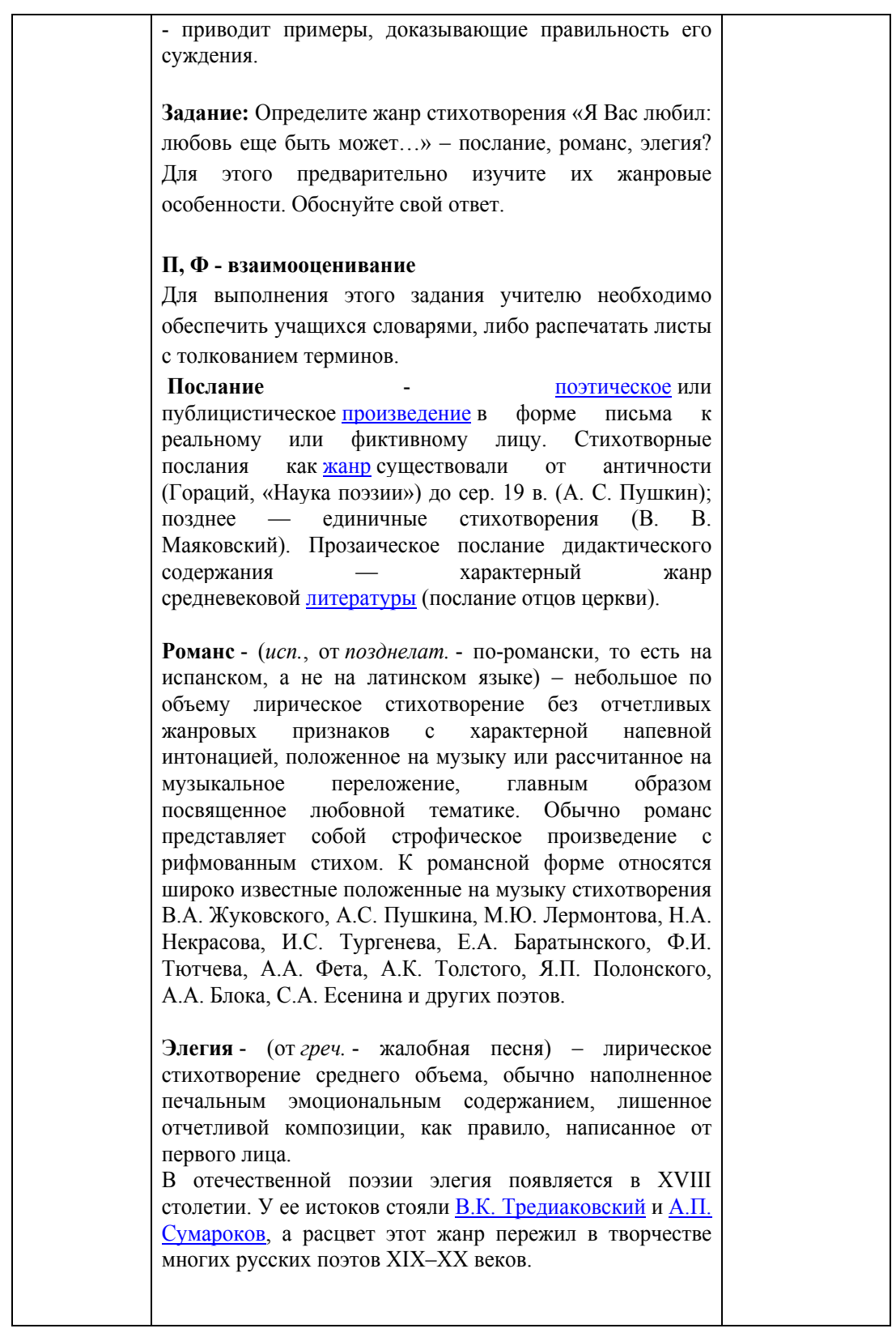




\begin{tabular}{|c|c|}
\hline $\begin{array}{l}\text { Конец урока } \\
2 \text { минут }\end{array}$ & $\begin{array}{l}\text { Рефлексия. } \\
\text { Учащиеся напишут «лист пожелания» однокласснику. На } \\
\text { листе они могут дать комментарий ответам } \\
\text { одноклассника, написать, что понравилось в его работе, к } \\
\text { чему нужно стремиться. } \\
\text { Домашнее задание: } \\
\text { Найти интересные факты о жизни и творчестве } \\
\text { М.Лермонтова. }\end{array}$ \\
\hline
\end{tabular}

\begin{tabular}{|c|c|c|c|}
\hline \multicolumn{2}{|c|}{$\begin{array}{l}\text { Раздел долгосрочного плана: } \\
\text { Любовь и честь. }\end{array}$} & \multicolumn{2}{|l|}{ Школа: } \\
\hline \multicolumn{2}{|l|}{ Дата: } & \multicolumn{2}{|l|}{ ФИО учителя: } \\
\hline \multicolumn{2}{|l|}{ Класс: 8} & \begin{tabular}{|l|} 
Количество \\
присутствующих:
\end{tabular} & отсутствующих: \\
\hline Тема урока & \multicolumn{3}{|c|}{$\begin{array}{l}\text { А.С. Пушкина. Я вас любил: любовь еще, быть может } \\
\text { На холмах Грузии }\end{array}$} \\
\hline $\begin{array}{l}\text { Цели } \\
\text { обучения, } \\
\text { которые } \\
\text { достигаются } \\
\text { на данном } \\
\text { уроке } \\
\text { (ссылка на } \\
\text { учебную } \\
\text { программу) }\end{array}$ & \multicolumn{3}{|c|}{ 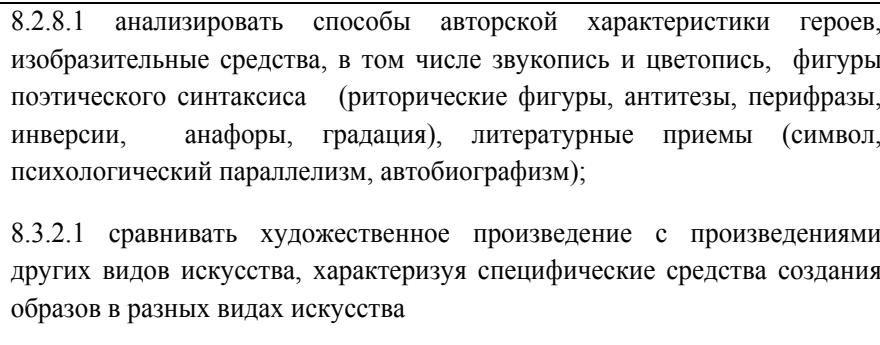 } \\
\hline Цели урока & \multicolumn{3}{|c|}{ 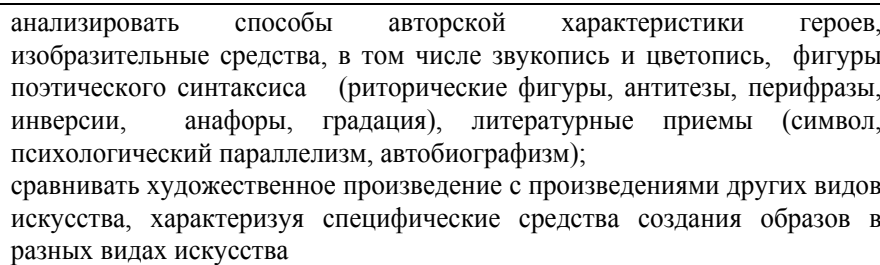 } \\
\hline
\end{tabular}

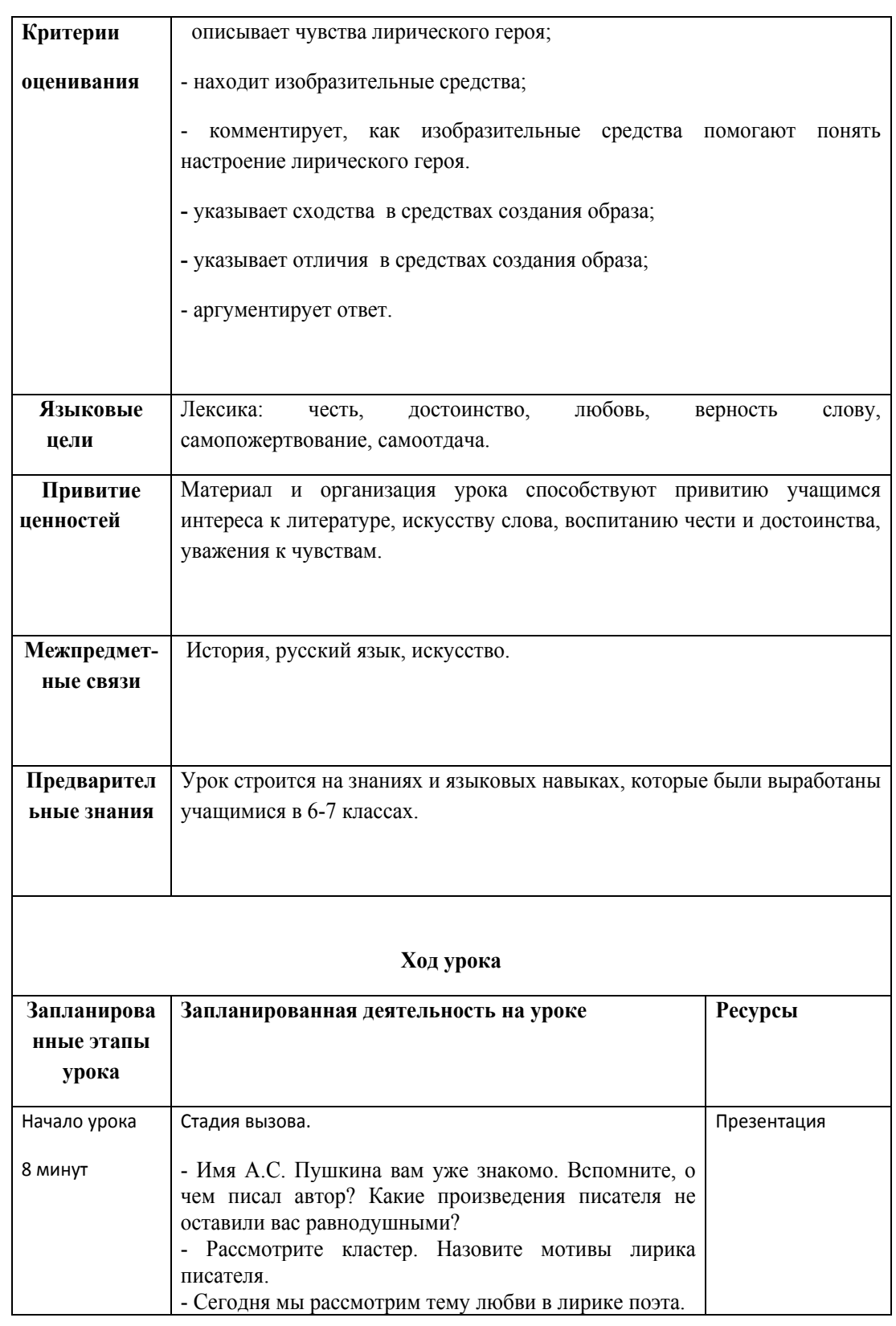




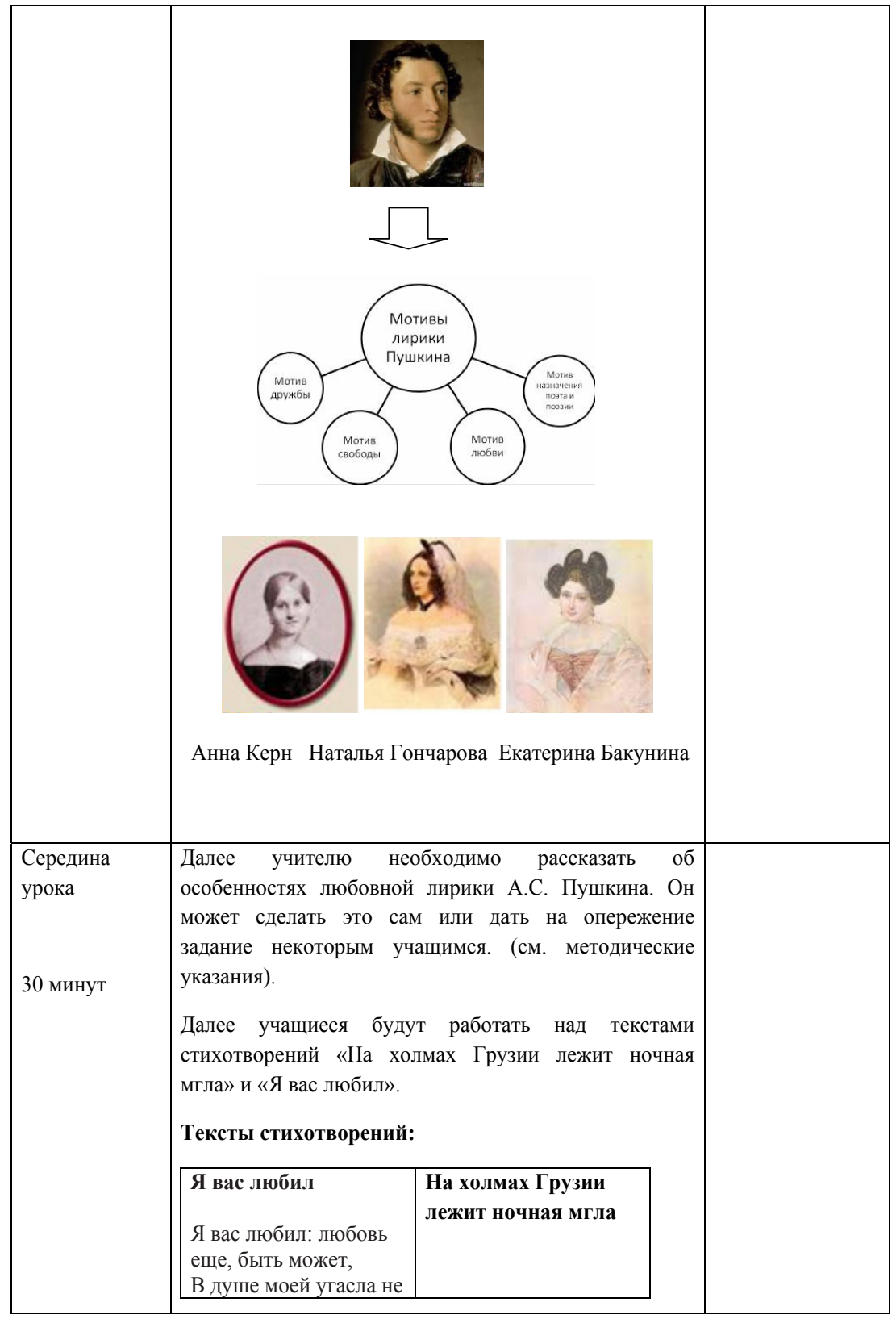

\begin{tabular}{|c|c|}
\hline 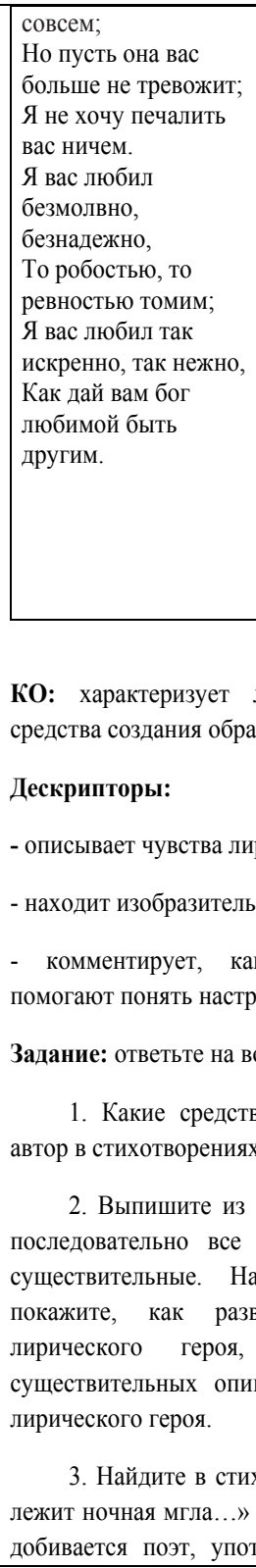 & 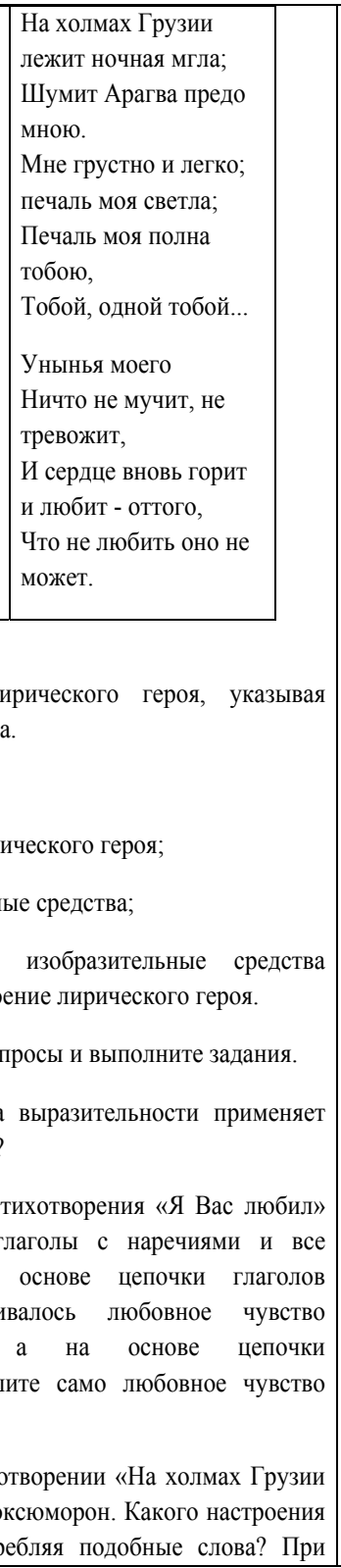 \\
\hline
\end{tabular}




\begin{tabular}{|c|c|c|}
\hline & $\begin{array}{l}\text { необходимости используйте литературоведческий } \\
\text { словарь. } \\
\text { Спикеры представят работу групп. } \\
\text { Г, Ф - обратная связь учителя } \\
\text { ко: сравнивает лирическое произведение с } \\
\text { произведениями других видов искусства. } \\
\text { Дескрипторы: } \\
\text { - указывает сходства в средствах создания образа; } \\
\text { - указывает отличия в средствах создания образа; } \\
\text { - аргументирует ответ. } \\
\text { Задание: Прослушайте романсы Римского-Корсакова } \\
\text { «На холмах Грузии лежит ночная мгла» в исполнении } \\
\text { Ирины Архиповой и романс Александра Алябьева «Я } \\
\text { вас любил» в исполнении Виктора Пенкина. Какой из } \\
\text { двух романсов вам понравился больше всего? Какой } \\
\text { ближе всего к авторской идее? Обоснуйте свой ответ. } \\
\text { Спикеры представят работу групп. } \\
\text { Г, Ф - взаимооценивание }\end{array}$ & 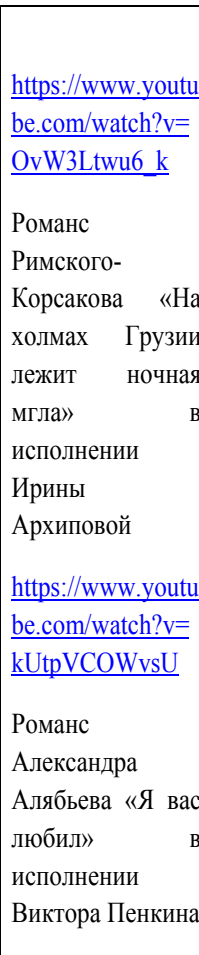 \\
\hline $\begin{array}{l}\text { Конец урока } \\
2 \text { минут }\end{array}$ & $\begin{array}{l}\text { Рефлексия. } \\
\text { Приём «Рюкзак» } \\
\text { Учащиеся зафиксируют свои продвижения в учебе, в } \\
\text { отношениях с другими. Рюкзак перемещается от } \\
\text { одного ученика к другому. Каждый не просто } \\
\text { фиксирует успех, но и приводит конкретный пример. } \\
\text { Если нужно собраться с мыслями, можно сказать } \\
\text { «пропускаю ход». } \\
\text { Домашнее задание: }\end{array}$ & \\
\hline
\end{tabular}

\begin{tabular}{|c|c|c|c|}
\hline \multicolumn{2}{|c|}{$\begin{array}{l}\text { Раздел долгосрочного плана: } \\
\text { Любовь и честь. }\end{array}$} & \multicolumn{2}{|l|}{ Школа: } \\
\hline \multicolumn{2}{|l|}{ Дата: } & \multicolumn{2}{|l|}{ ФИО учителя: } \\
\hline \multicolumn{2}{|l|}{ Класс: 8} & \begin{tabular}{|l|} 
Количество \\
присутствующи \\
х:
\end{tabular} & \begin{tabular}{|l} 
отсутствующих: \\
\end{tabular} \\
\hline Тема урока & \multicolumn{3}{|c|}{ М.Ю. Лермонтова. У ног других не забывал } \\
\hline $\begin{array}{l}\text { Цели обучения, } \\
\text { которые } \\
\text { достигаются на } \\
\text { данном уроке } \\
\text { (ссылка } \\
\text { учебную } \\
\text { программу) }\end{array}$ & \multicolumn{3}{|c|}{$\begin{array}{l}\text { 8.2.2.1 определять тему и идею произведения, выражая своё мнение о } \\
\text { проблематике; } \\
\text { 8.2.8.1 анализировать способы авторской характеристики героев, } \\
\text { изобразительные средства, в том числе звукопись и цветопись, } \\
\text { фигуры поэтического синтаксиса (риторические фигуры, антитезы, } \\
\text { перифразы, инверсии, анафоры, градация), литературные приемы } \\
\text { (символ, психологический параллелизм, автобиографизм). }\end{array}$} \\
\hline Ka & \multicolumn{3}{|c|}{$\begin{array}{l}\text { • определять тему и идею произведения, выражая своё мнение о } \\
\text { проблематике; } \\
\text { - анализировать способы авторской характеристики героев, } \\
\text { изобразительные средства, в том числе звукопись и цветопись, } \\
\text { фигуры поэтического синтаксиса (риторические фигуры, } \\
\text { антитезы, перифразы, инверсии, анафоры, градаци), } \\
\text { литературные приемы (символ, психологический } \\
\text { параллелизм, автобиографизм). }\end{array}$} \\
\hline Критерии & \multicolumn{3}{|c|}{$\begin{array}{l}\text { определяет тему и основную мысль лирического произведения. } \\
\text { - определяет ключевые слова и фразы в тексте; } \\
\text { - описывает эффект, созданный ключевыми словами; } \\
\text { - объясняет, каким образом конкретные слова и фразы раскрывают } \\
\text { ключевую тему. } \\
\text { - описывает чувства лирического героя; } \\
\text { - находит изобразительные средства; } \\
\text { - комментирует, как изобразительные средства помогают понять } \\
\text { настроение лирического героя. }\end{array}$} \\
\hline Языковые цели & \multicolumn{3}{|c|}{$\begin{array}{l}\text { Лексика: честь, достоинство, любовь, верность слову, } \\
\text { самопожертвование, самоотдача. }\end{array}$} \\
\hline $\begin{array}{l}\text { ривитие } \\
\text { стей }\end{array}$ & \multicolumn{3}{|c|}{$\begin{array}{l}\text { Материал и организация урока способствуют привитию учащимся } \\
\text { интереса к литературе, искусству слова, воспитанию чести и } \\
\text { достоинства, уважения к чувствам. }\end{array}$} \\
\hline
\end{tabular}




\begin{tabular}{|c|c|c|c|}
\hline $\begin{array}{l}\text { Межпредмет- } \\
\text { ные связи }\end{array}$ & \multicolumn{3}{|c|}{ История, русский язык, искусство. } \\
\hline $\begin{array}{l}\text { Предварительн } \\
\text { ые знания }\end{array}$ & \multicolumn{3}{|c|}{$\begin{array}{l}\text { Урок строится на знаниях и языковых навыках, которые были } \\
\text { выработаны учащимися в 6-7 классах. }\end{array}$} \\
\hline \multicolumn{4}{|l|}{ Ход урока } \\
\hline $\begin{array}{l}\text { Запланирован } \\
\text { ные этапы } \\
\text { урока }\end{array}$ & \multicolumn{2}{|c|}{ Запланированная деятельность на уроке } & Ресурсы \\
\hline $\begin{array}{l}\text { Начало урока } \\
8 \text { минут }\end{array}$ & \multicolumn{2}{|c|}{$\begin{array}{l}\text { - Расскажите сведения о жизни и творчестве М.Ю. } \\
\text { Лермонтова, которые вам известны. } \\
\text { - Какие произведения писателя вы читали? } \\
\text { - Посмотрите учебный ролик «М.Ю. Лермонтов. } \\
\text { Основные мотивы лирики». Законспектируйте в } \\
\text { тетрадь материал, который раскрывает особенности } \\
\text { любовной лирики писателя. } \\
\text { к, Ф }\end{array}$} & $\begin{array}{l}\text { Презентация } \\
\text { https://www.you } \\
\text { tube.com/watch } \\
\text { ?v=QKqedE_tIa } \\
\mathrm{g} \\
\text { М.Ю. } \\
\text { Лермонтов. } \\
\text { Основные } \\
\text { мотивы } \\
\text { лирики. }\end{array}$ \\
\hline $\begin{array}{l}\text { Середина } \\
\text { урока }\end{array}$ & \multicolumn{2}{|c|}{$\begin{array}{lrrrr}\text { Далее учащиеся } & \text { будут } & \text { работать } & \text { с } & \text { текстами } \\
\text { стихотворений. Учитель может рассказать об истории } \\
\text { возникновения } & \text { этих } & \text { стихотворений. } & \text { (см. } \\
\text { методические рекомендации). } & & \end{array}$} & \\
\hline 30 минут & $\begin{array}{l}\text { К Л.- (У ног других не } \\
\text { забывал...) } \\
\text { У ног других не } \\
\text { забывал } \\
\text { Я взор твоих очей; } \\
\text { Любя других, я лишь } \\
\text { страдал } \\
\text { Любовью прежних }\end{array}$ & \begin{tabular}{|l}
$\boldsymbol{K}_{\text {*** (Я не унижусь }}$ \\
пред тобою...) \\
Я не унижусь пред \\
тобою; \\
Ни твой привет, ни \\
твой укор \\
Не властны над моей
\end{tabular} & \\
\hline
\end{tabular}

\begin{tabular}{|c|c|}
\hline $\begin{array}{l}\text { дней; } \\
\text { Так память, демон- } \\
\text { властелин, } \\
\text { Всё будит старину, } \\
\text { И я твержу один, } \\
\text { один: } \\
\text { Люблю, люблю } \\
\text { одну! } \\
\text { Принадлежишь } \\
\text { другому ты, } \\
\text { Забыт певец тобой; } \\
\text { С тех пор влекут меня } \\
\text { мечты } \\
\text { Прочь от земли } \\
\text { родной; } \\
\text { Корабль умчит меня } \\
\text { от ней } \\
\text { В безвестную } \\
\text { страну, } \\
\text { И повторит волна } \\
\text { морей: } \\
\text { Люблю, люблю } \\
\text { одну! } \\
\text { И не узнает шумный } \\
\text { свет, } \\
\text { Кто нежно так } \\
\text { любим, } \\
\text { Как я страдал и } \\
\text { сколько лет } \\
\text { Я памятью томим; } \\
\text { И где бы я ни стал } \\
\text { искать } \\
\text { Былую тишину, } \\
\text { Все сердце будет мне } \\
\text { шептать: } \\
\text { Люблю, люблю } \\
\text { одну! }\end{array}$ & $\begin{array}{l}\text { душою. } \\
\text { Знай: мы чужие с этих } \\
\text { пор. } \\
\text { Ты позабыла: я } \\
\text { свободы } \\
\text { Для заблужденья не } \\
\text { отдам; } \\
\text { И так пожертвовал я } \\
\text { годы } \\
\text { Твоей улыбке и } \\
\text { глазам, } \\
\text { И так я слишком долго } \\
\text { видел } \\
\text { В тебе надежду юных } \\
\text { дней } \\
\text { И целый мир } \\
\text { возненавидел, } \\
\text { Чтобы тебя любить } \\
\text { сильней. } \\
\text { Как знать, быть } \\
\text { может, те мгновенья, } \\
\text { Что протекли у ног } \\
\text { твоих, } \\
\text { Я отнимал у } \\
\text { вдохновенья! } \\
\text { А чем ты заменила их? } \\
\text { Быть может, мыслею } \\
\text { небесной } \\
\text { И силой духа убежден, } \\
\text { Я дал бы миру дар } \\
\text { чудесный, }\end{array}$ \\
\hline
\end{tabular}




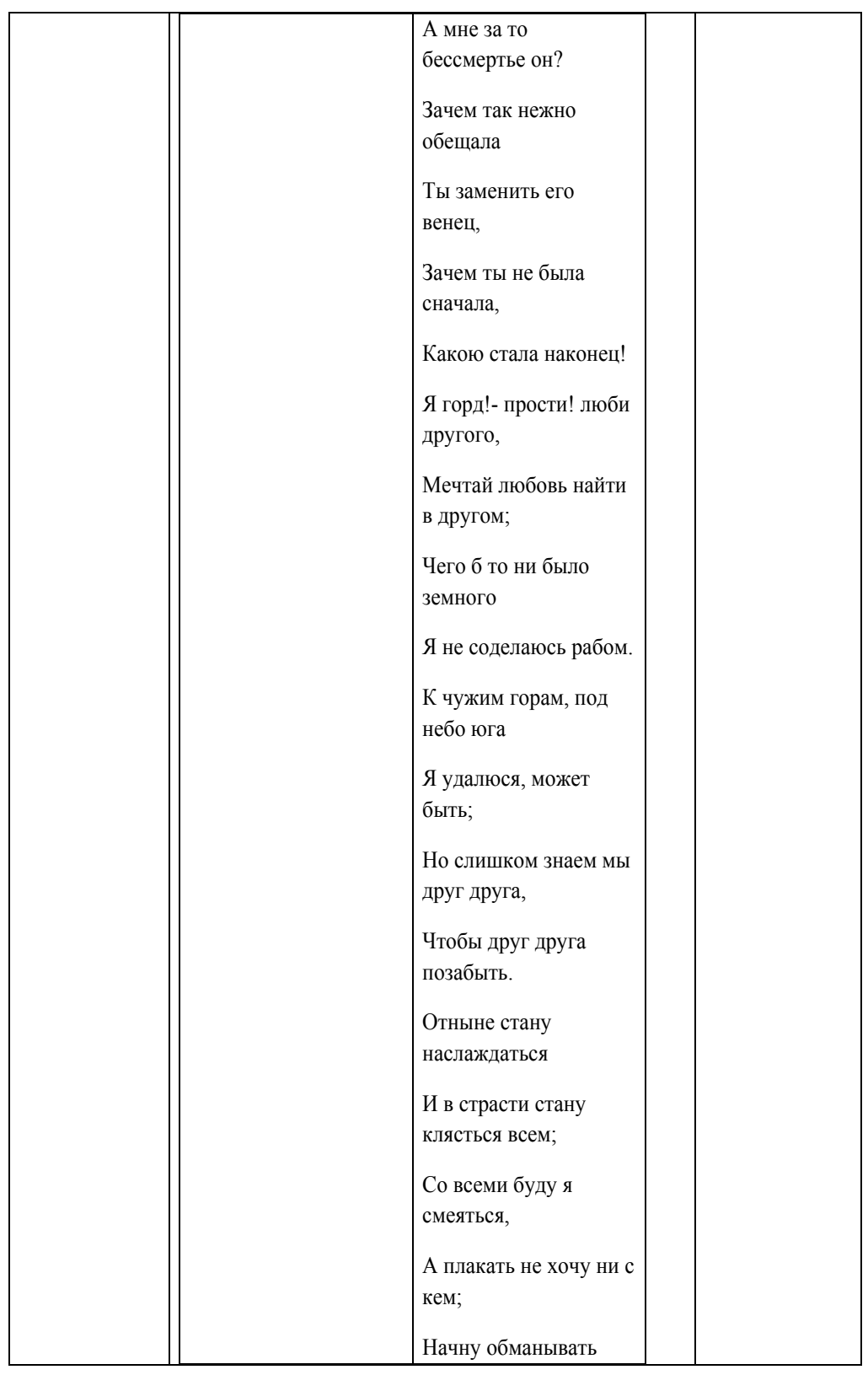

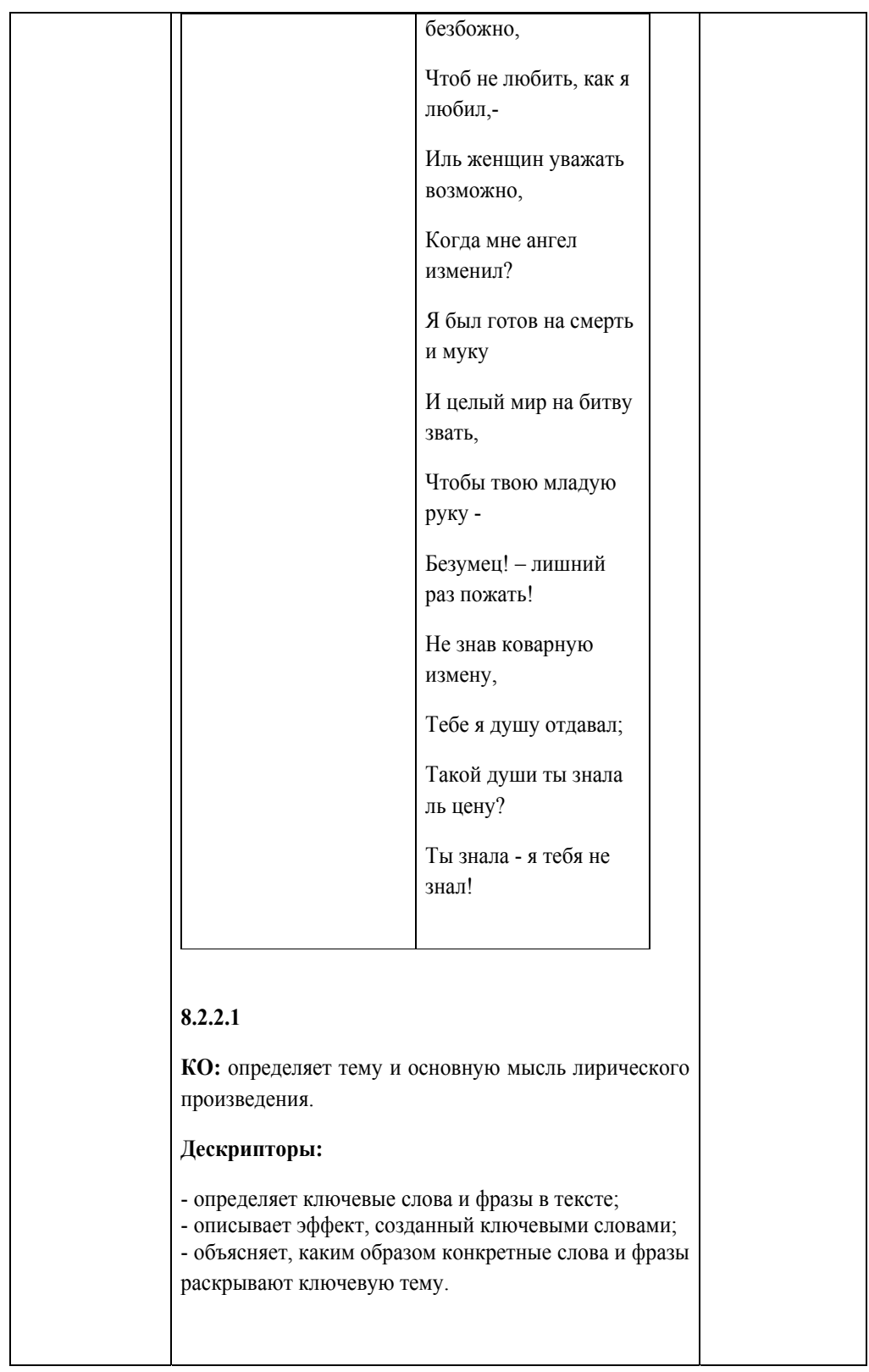




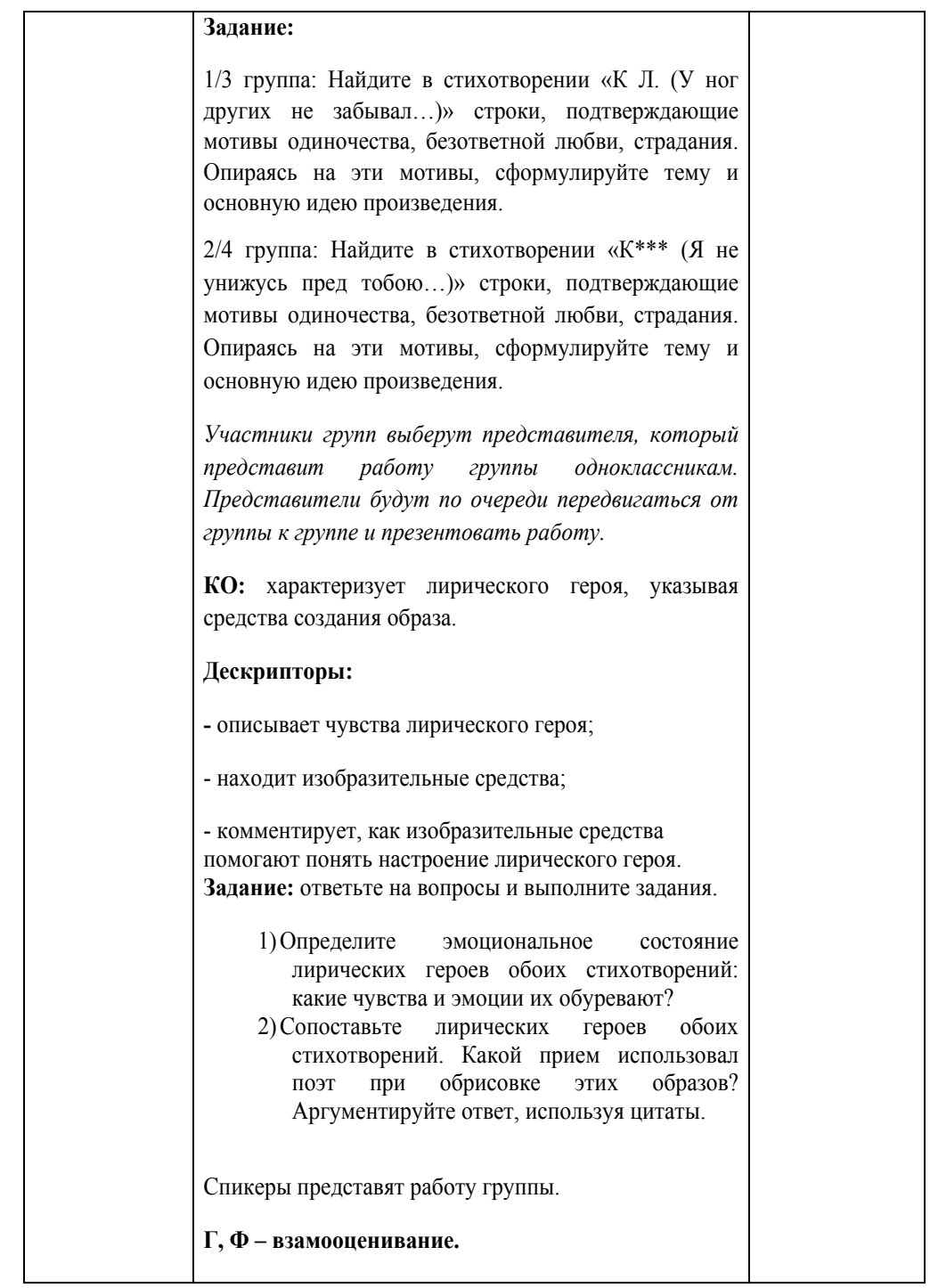

\begin{tabular}{|l|l|l|}
\hline Конец урока & Рефлексия. & \\
2 минут & Учащиеся проанализируют свою деятельность на \\
уроке, закончив предложения: & \\
Сегодня на уроке я & Я научился \\
& $\begin{array}{l}\text { Я затруднялся } \\
\text { Домашнее задание: } \\
\text { Найти интересные факты о жизни и творчестве Ф.И. } \\
\text { Тютчева. }\end{array}$ & \\
\hline
\end{tabular}

КСП 8 класс АНАЛИЗ СТИХОТВОРЕНИЯ А.А. ФеТа.

\begin{tabular}{|c|c|c|c|}
\hline \multicolumn{2}{|c|}{$\begin{array}{l}\text { Раздел долгосрочного п плана: } \\
\text { Любовь и честь. }\end{array}$} & \multicolumn{2}{|l|}{ Школа: } \\
\hline \multicolumn{2}{|l|}{ Дата: } & \multicolumn{2}{|c|}{ ФИО учителя: Кузнецова А.Н. } \\
\hline \multicolumn{2}{|l|}{ Класс: 8} & $\begin{array}{l}\text { Количество } \\
\text { присутствующ } \\
\text { их: }\end{array}$ & отсутствующих: \\
\hline Тема урока & \multicolumn{3}{|c|}{$\begin{array}{l}\text { А.А. Фета. Шепот, робкое дыхание } \\
\text { Какое счастье: и ночь, и мы один! } \\
\text { Сияла ночь. Луной был полон сад }\end{array}$} \\
\hline $\begin{array}{lr}\text { Цели } & \text { обучения, } \\
\text { которые } & \\
\text { достигаются } & \text { на } \\
\text { данном } & \text { уроке } \\
\text { (ссылка } & \text { на } \\
\text { учебную } & \\
\text { программу) }\end{array}$ & \multicolumn{3}{|c|}{$\begin{array}{l}\text { 8.2.2.1 определять тему и идею произведения, выражая своё } \\
\text { мнение о проблематике; } \\
\text { 8.2.8.1 анализировать способы авторской характеристики героев, } \\
\text { изобразительные средства, в том числе звукопись и цветопись, } \\
\text { фигуры поэтического синтаксиса (риторические фигуры, } \\
\text { антитезы, перифразы, инверсии, анафоры, градация), } \\
\text { литературные приемы (символ, психологический параллелизм, } \\
\text { автобиографизм). }\end{array}$} \\
\hline Іели & \multicolumn{3}{|c|}{$\begin{array}{l}\text { определять тему и идею произведения, выражая своё мнение о } \\
\text { проблематике; } \\
\text { анализировать способы авторской характеристики героев, } \\
\text { изобразительные средства, в том числе звукопись и цветопись, } \\
\text { фигуры поэтического синтаксиса (риторические фигуры, } \\
\text { антитезы, перифразы, инверсии, анафоры, градация), } \\
\text { литературные приемы (символ, психологический параллелизм, } \\
\text { автобиографизм). }\end{array}$} \\
\hline & \multicolumn{3}{|c|}{$\begin{array}{l}\text { определяет тему и основную мысль лирического произведения. } \\
\text { характеризует лирического героя, у указывая средства создания }\end{array}$} \\
\hline
\end{tabular}




\begin{tabular}{|c|c|c|c|}
\hline & & \multicolumn{2}{|c|}{$\begin{array}{l}\text { образа. } \\
\text { - описывает чувства лирического героя; } \\
\text { - находит изобразительные средства; } \\
\text { - комментирует, как изобразительные средства помогают понять } \\
\text { настроение лирического героя. }\end{array}$} \\
\hline \multicolumn{2}{|c|}{ Языковые цели } & \multicolumn{2}{|c|}{$\begin{array}{l}\text { Лексика: честь, достоинство, любовь, } \\
\text { самопожертвование, самоосдача. }\end{array}$} \\
\hline \multicolumn{2}{|c|}{$\begin{array}{l}\text { Привитие } \\
\text { ценностей }\end{array}$} & \multicolumn{2}{|c|}{$\begin{array}{l}\text { Материал и организация урока способствуют привитию учащимся } \\
\text { интереса к литературе, искусству слова, воспитанию чести и } \\
\text { достоинства, уважения к чувствам. }\end{array}$} \\
\hline \multicolumn{2}{|c|}{$\begin{array}{l}\text { Межпредметные } \\
\text { связи }\end{array}$} & \multicolumn{2}{|l|}{ История, русский язык, искусство. } \\
\hline \multicolumn{2}{|c|}{$\begin{array}{l}\text { Предварительные } \\
\text { знания }\end{array}$} & \multicolumn{2}{|c|}{$\begin{array}{l}\text { Урок строится на знаниях и языковых навыках, которые были } \\
\text { выработаны учащимися в 6-7 классах. }\end{array}$} \\
\hline \multicolumn{4}{|l|}{ Ход урока } \\
\hline $\begin{array}{l}\text { Запланиро- } \\
\text { ванные } \\
\text { этапы урока }\end{array}$ & \multicolumn{2}{|c|}{ Запланированная деятельность на уроке } & Ресурсы \\
\hline Начало урока & \multicolumn{2}{|c|}{$\begin{array}{l}\text { Стадия вызова } \\
\text { - Что вам известно о творчестве А.А. Фета? } \\
\text { - Посмотрите музыкальную презентацию «Лирика } \\
\text { А.Фета». Предположите, почему автор презентации } \\
\text { сопровождает произведения А.Фета красивейшими } \\
\text { фотографиями природы? }\end{array}$} & $\begin{array}{l}\text { Презентация } \\
\text { https://www.yo } \\
\underline{\text { utube.com/watc }} \\
\underline{\text { h?v=iHiwWqzb }} \\
\frac{\text { XCc }}{\text { Лирика А.Фета }}\end{array}$ \\
\hline
\end{tabular}

\begin{tabular}{|c|c|c|}
\hline $\begin{array}{l}\text { Середина } \\
\text { урока } \\
30 \text { минут }\end{array}$ & 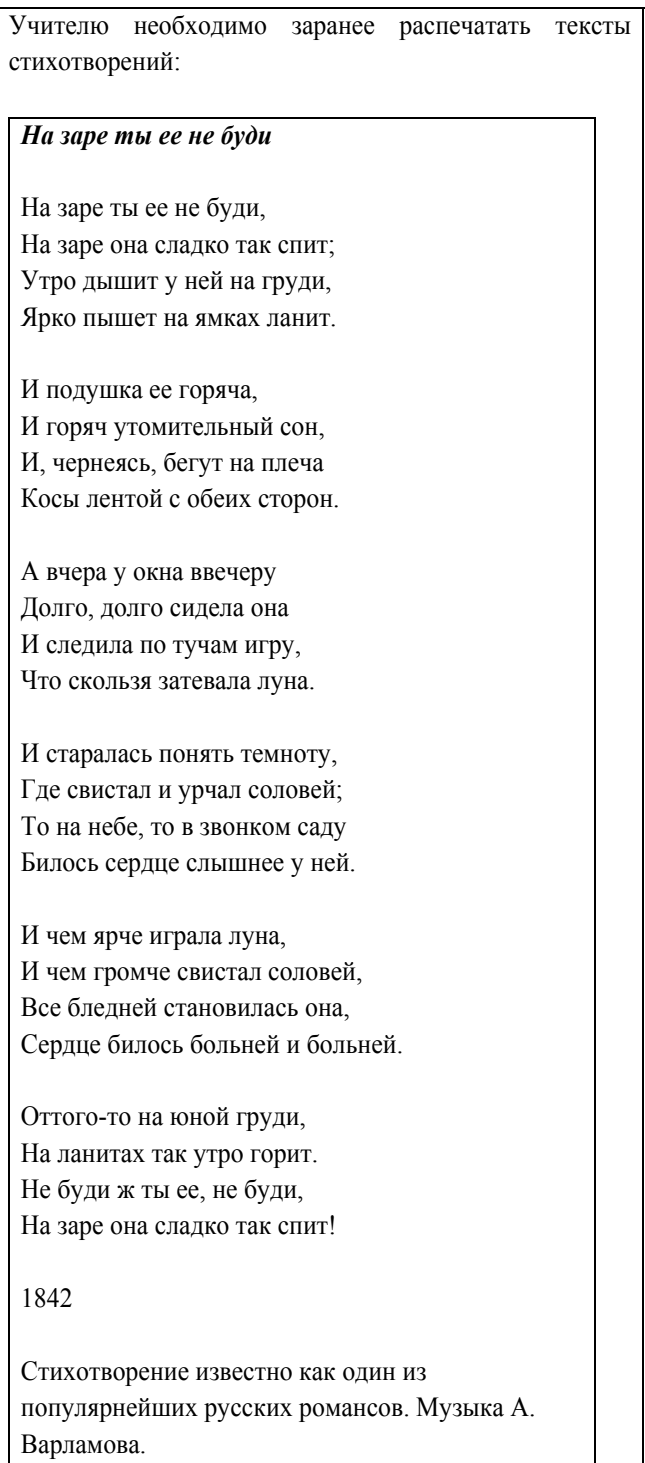 & 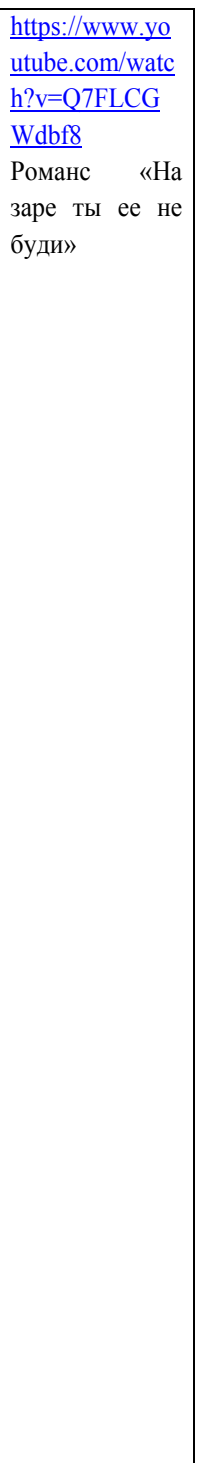 \\
\hline
\end{tabular}




\begin{tabular}{|c|c|c|c|c|}
\hline \multicolumn{4}{|c|}{$\begin{array}{l}\text { Сияла ночь... } \\
\text { Сияла ночь. Луной был полон сад. Лежали } \\
\text { Лучи у наших ног в гостиной без огней. } \\
\text { Рояль был весь раскрыт, и струны в нем дрожали, } \\
\text { Как и сердца у нас за песнию твоей. }\end{array}$} & $\begin{array}{l}\underline{\text { https://www.yo }} \\
\underline{\text { utube.com/watc }} \\
\underline{h ? v=j 8 f 7 z F A x l} \\
\underline{\text { V8 }} \\
\text { Романс «Сияла } \\
\text { ночь, луной } \\
\text { был полон сад» }\end{array}$ \\
\hline \multicolumn{4}{|c|}{$\begin{array}{l}\text { Ты пела до зари, в слезах изнемогая, } \\
\text { Что ты одна - любовь, что нет любви иной, } \\
\text { И так хотелось жить, чтоб, звука не роняя, } \\
\text { Тебя любить, обнять и плакать над тобой. }\end{array}$} & \\
\hline \multicolumn{4}{|c|}{$\begin{array}{l}\text { И много лет прошло, томительных и скучных, } \\
\text { И вот в тиши ночной твой голос слышу вновь, } \\
\text { И веет, как тогда, во вздохах этих звучных, } \\
\text { Что ты одна - вся жизнь, что ты одна - любовь. }\end{array}$} & \\
\hline \multicolumn{4}{|c|}{$\begin{array}{l}\text { Что нет обид судьбы и сердца жгучей муки, } \\
\text { А жизни нет конца, и цели нет иной, } \\
\text { Как только веровать в рыдающие звуки, } \\
\text { Тебя любить, обнять и плакать над тобой! }\end{array}$} & \\
\hline \multicolumn{4}{|c|}{$\begin{array}{l}\text { Учащиеся будут слушать романсы и следить за } \\
\text { тональностью исполнения по текстам стихотворений. } \\
\text { 8.2.2.1 } \\
\text { кО: определяет тему и основную мысль лирического } \\
\text { произведения. } \\
\text { Дескрипторы: } \\
\text { - определяет ключевые слова и фразы в тексте; } \\
\text { - описывает эффект, созданный ключевыми словами; } \\
\text { - объясняет, каким образом конкретные слова и фразы } \\
\text { раскрывают ключевую тему. } \\
\text { Задание: } \\
\text { 1.Во время прослушивания романсов выделите в } \\
\text { текстах стихотворений ключевые слова и фразы. } \\
\text { 2.Заполните таблицу: }\end{array}$} & \\
\hline $\begin{array}{l}\text { Стихотворен } \\
\text { ие }\end{array}$ & \begin{tabular}{|l|} 
Ключев \\
ые слова \\
и \\
выражен \\
ия \\
\end{tabular} & $\begin{array}{l}\text { Эффект, } \\
\text { который } \\
\text { создают } \\
\text { ключевые } \\
\text { слова } \\
\end{array}$ & $\begin{array}{l}\text { Тема/основна } \\
\text { я мысль }\end{array}$ & \\
\hline
\end{tabular}

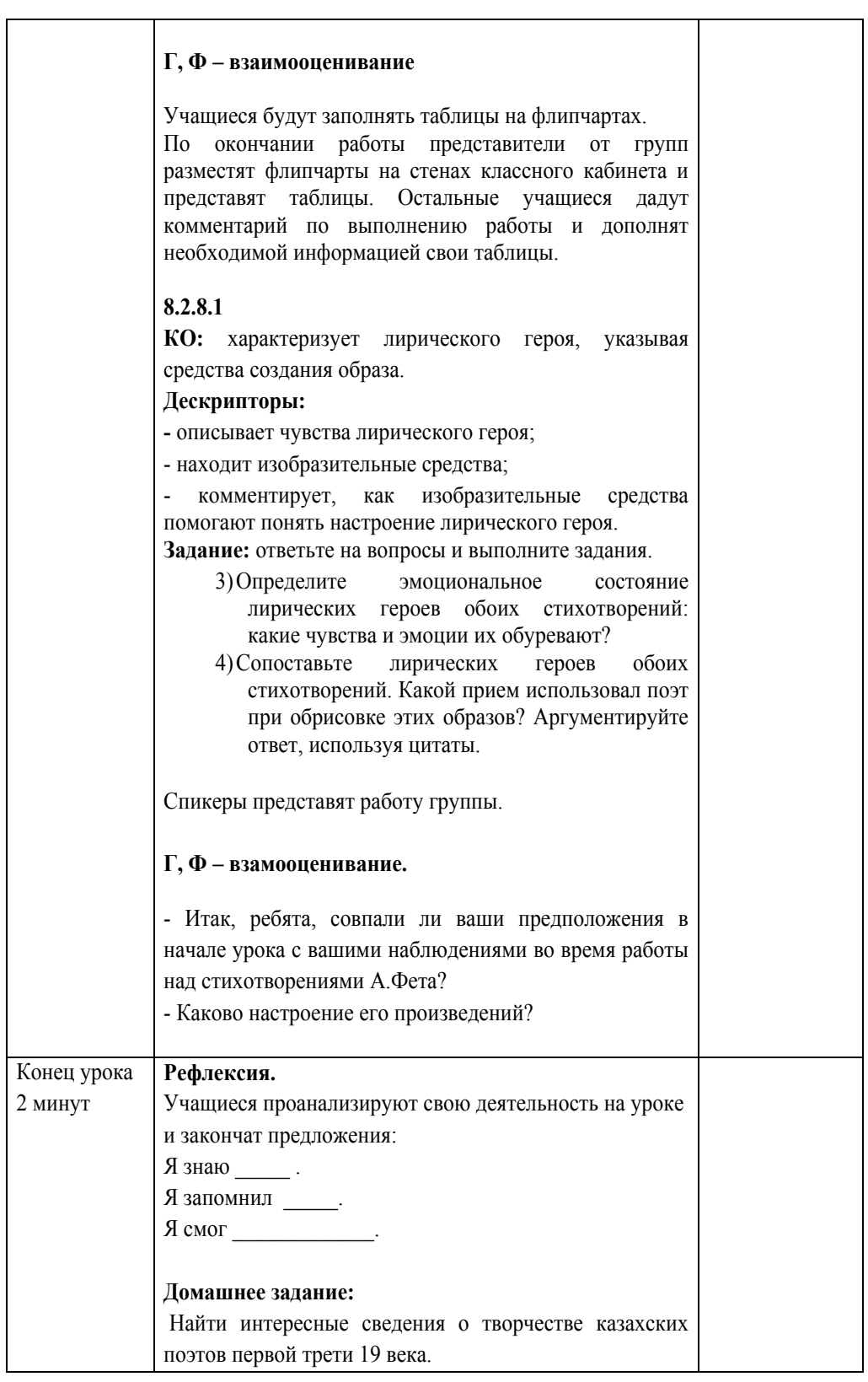


Олжас Омарович Сулейменов

\begin{tabular}{|c|c|c|c|}
\hline \multicolumn{2}{|c|}{$\begin{array}{l}\text { Раздел долгосрочного плана: } \\
\text { Любовь и честь }\end{array}$} & \multicolumn{2}{|l|}{ Школа: } \\
\hline \multicolumn{2}{|l|}{ Дата: } & \multicolumn{2}{|l|}{ ФИО учителя: } \\
\hline \multicolumn{2}{|l|}{ Класс: 8} & \begin{tabular}{|l|} 
Количество \\
присутствующ \\
их:
\end{tabular} & отсутствующих: \\
\hline Тема урока & \multicolumn{3}{|c|}{$\begin{array}{l}\text { Олжас Омарович Сулейменов } \\
\text { «Последнее слово акына Смета». }\end{array}$} \\
\hline $\begin{array}{l}\text { Цели обучения, } \\
\text { которые } \\
\text { достигаются на } \\
\text { данном уроке } \\
\text { (ссылка на } \\
\text { учебную } \\
\text { программу) }\end{array}$ & \multicolumn{3}{|c|}{ 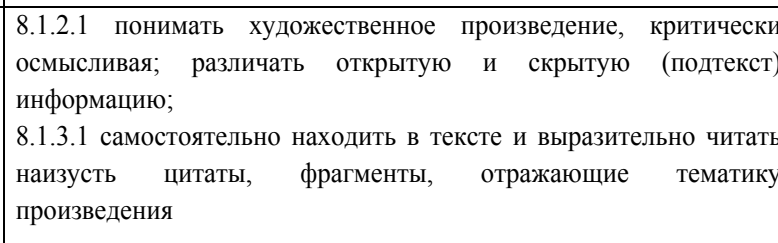 } \\
\hline Цели урока & \multicolumn{3}{|c|}{$\begin{array}{l}\text { понимать художественное произведение, критически осмысливая; } \\
\text { различать открытую и скрытую (подтекст) информацию; } \\
\text { самостоятельно находить в тексте и выразительно читать } \\
\text { наизусть цитаты, фрагменты, отражающие тематику } \\
\text { произведения }\end{array}$} \\
\hline $\begin{array}{l}\text { Критерии } \\
\text { оценивания }\end{array}$ & \multicolumn{3}{|c|}{$\begin{array}{l}\text { демонстрирует понимание художественного произведения. } \\
\text { - понимает тему произведения (открытая информация); } \\
\text { - раскрывает смысл произведения (подразумеваемая } \\
\text { информация); } \\
\text { - делает вывод, демонстрируя понимание цели работы. } \\
\text { комментирует выбранную цитату; } \\
\text { - рассуждает, почему выбранная цитата более точно и глубоко } \\
\text { раскрывает тему произведения и характер персонажа; } \\
\text { - приводит примеры из текста, подтверждающие его мнение. }\end{array}$} \\
\hline Языковые цели & \multicolumn{3}{|c|}{$\begin{array}{l}\text { Расширение словарного запаса: акын, чалый, жаулык, молодка, } \\
\text { песчататься, жаулык. }\end{array}$} \\
\hline $\begin{array}{l}\text { Привитие } \\
\text { ценностей }\end{array}$ & \multicolumn{3}{|c|}{$\begin{array}{l}\text { Искусство слова, ценность любви, самопожертвование, честь, } \\
\text { прощение. }\end{array}$} \\
\hline $\begin{array}{l}\text { Межпредмет- } \\
\text { ные связи }\end{array}$ & \multicolumn{3}{|c|}{ Казахская литература, история. } \\
\hline $\begin{array}{l}\text { Предварительн } \\
\text { ые знания }\end{array}$ & \multicolumn{3}{|c|}{$\begin{array}{l}\text { Данный раздел основан на содержании, навыках и знаниях, } \\
\text { приобретенных учащимися в } 7 \text { классе. }\end{array}$} \\
\hline
\end{tabular}

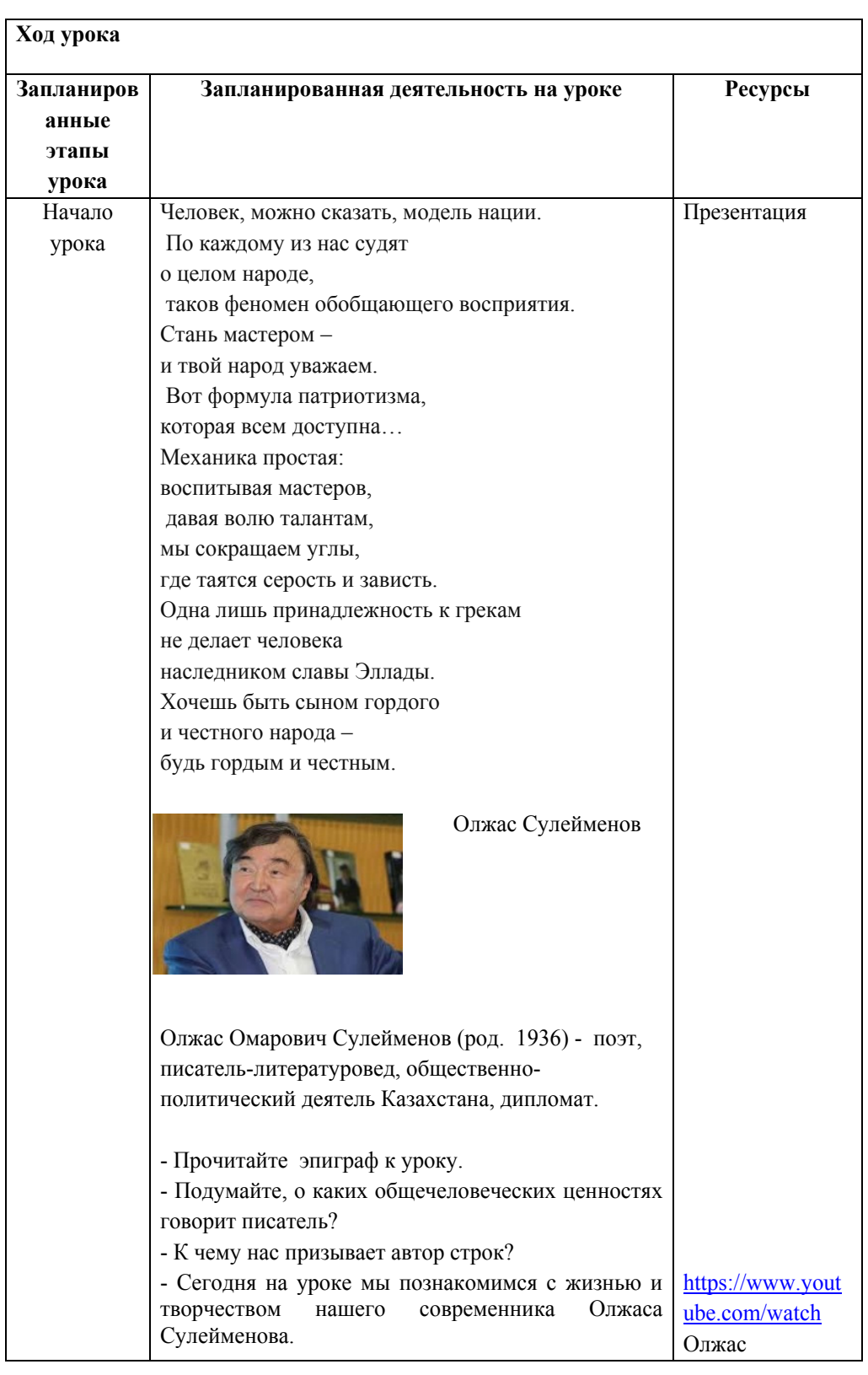




\begin{tabular}{|c|c|c|}
\hline & $\begin{array}{l}\text { Далее заранее подготовленные учащиеся } \\
\text { расскажут краткую биографию писателя. (см. } \\
\text { методические указания) } \\
\text { Учитель подведет итог после сообщения учащихся: } \\
\text { - Известность получил как автор лингвистических } \\
\text { исследований, в частности, посвященных } \\
\text { тюркским элементам «Слова о полку Игореве». По } \\
\text { сценариям Олжаса Сулейменова поставлены } \\
\text { фильмы «земля отцов» (1966), «Синий маршрут» } \\
\text { (1968), «Красная полынь» («Махамбет») о } \\
\text { казахском поэте ХІХ века Махамбете Утемисове и } \\
\text { «Ах, как интересно было в Петербурге» (о хане } \\
\text { Жангире). Олжаса Сулейменова причисляют к } \\
\text { поэтам-шестидесятникам, его друзьями были } \\
\text { Андрей Вознесенский, Евгений Евтушенко, Роберт } \\
\text { Рождественский. } \\
\text { - Сегодня мы поговорим с вами о произведении } \\
\text { О.Сулейменова «Последнее слово акына Смета» } \\
\text { - Серж Пьетро - академик, изобретатель, писал об } \\
\text { этом произведении так: «Великая философия! Но } \\
\text { философия веков». } \\
\text { - Еще один отзыв на это произведение: «Олжас } \\
\text { Сулейменов - великий поэт, и данное произведение } \\
\text { - очередное доказательство. Столько мудрости и } \\
\text { смысла». } \\
\text { - Сегодня и на последующих уроках мы с вами } \\
\text { попытаемся выяснить, в чем же заключается } \\
\text { мудрость этого стихотворения и какова его идея. }\end{array}$ & \begin{tabular}{|l} 
Сулейменов. \\
Воспоминания.
\end{tabular} \\
\hline $\begin{array}{c}\text { Середина } \\
\text { урока }\end{array}$ & $\begin{array}{l}\text { объясняет значение выделенных в тексте слов; } \\
\text { - понимает тему произведения (открытая } \\
\text { информация); } \\
\text { - раскрывает смысл произведения } \\
\text { (подразумеваемая информация); } \\
\text { - делает вывод. } \\
\text { Задание: } \\
\text { 1. Объясните значение слов: аркан, юрта, чалый, } \\
\text { молодка, песчататься, жаулык. } \\
\text { 2. Назовите тему произведения, аргументируйте } \\
\text { ответ. } \\
\text { 3. Сформулируйте идею произведения } \\
\text { 4. Как подтекст произведения помогает понять его } \\
\text { идеюе? } \\
\text { Спикеры от групп представят работу. } \\
\text { Г, Ф - взаимооценивание } \\
\text { кО: находит в тексте цитаты, отражающие } \\
\text { тематику произведения и характер персонажа. }\end{array}$ & $\begin{array}{l}\text { https://slovarozhe } \\
\text { gova.ru/ } \\
\text { Толковый } \\
\text { словарь Ожегова }\end{array}$ \\
\hline
\end{tabular}

\begin{tabular}{|c|c|}
\hline & 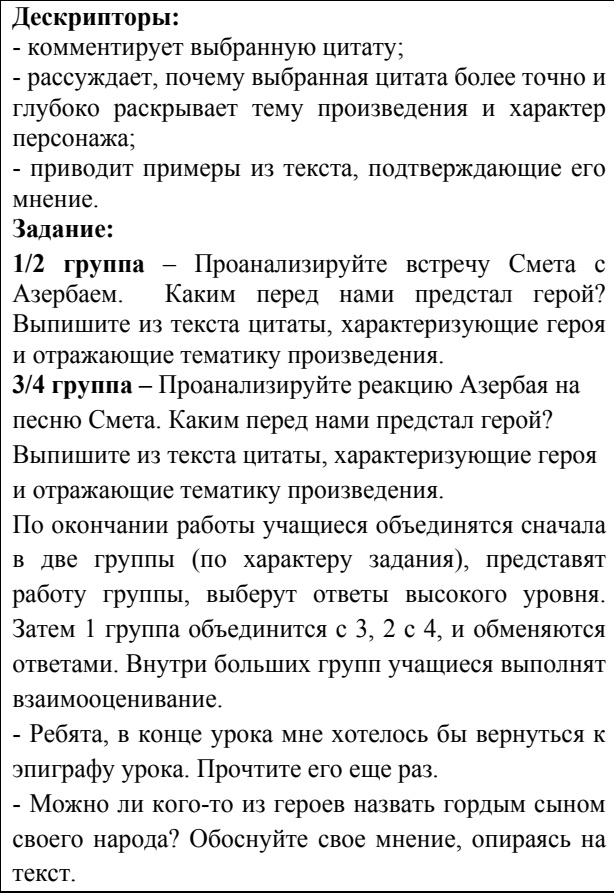 \\
\hline Конец урока & 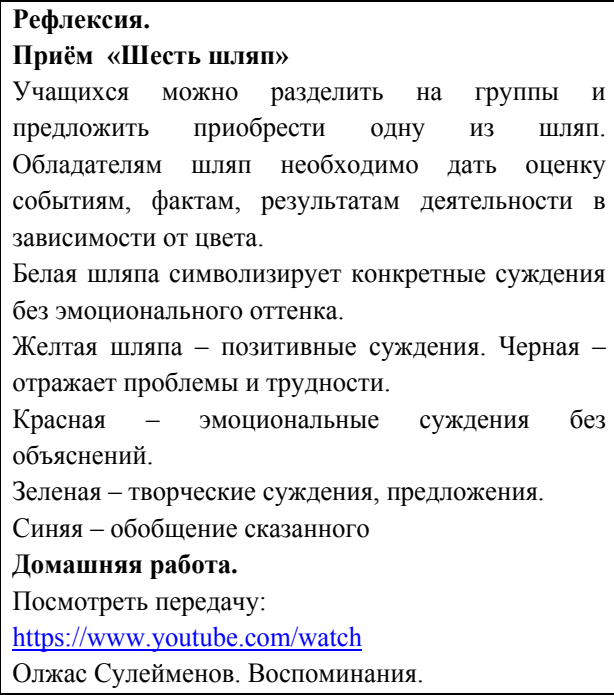 \\
\hline
\end{tabular}




\begin{tabular}{|c|c|}
\hline $\begin{array}{l}\text { Раздел: } \\
\text { Тема урока }\end{array}$ & $\begin{array}{l}\text { А.С.Пушкин«Евгений Онегин» } \\
\text { Онегин и Татьяна. } \\
\text { Сопоставительный анализ героев. } \\
\text { Татьяна -любимая героиня поэта. }\end{array}$ \\
\hline $\begin{array}{l}\text { Цели обучения. } \\
\text { Которые } \\
\text { необходимо } \\
\text { достичь на } \\
\text { данном уроке. }\end{array}$ & $\begin{array}{l}9 \text { ПО2 Понимать художественные произведения в деталях, } \\
\text { включая известную и неизвестную информацию. } \\
\text { 9АИ5Характеризовать героев произведения на основе деталей и } \\
\text { цитат из текста. }\end{array}$ \\
\hline \multirow{19}{*}{ 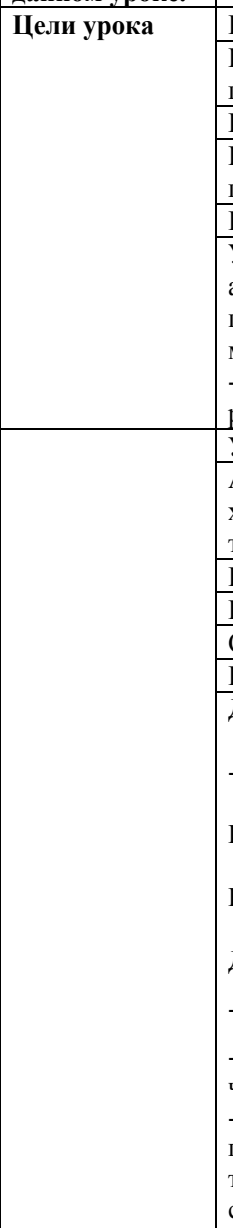 } & Все учащиеся смогут \\
\hline & $\begin{array}{l}\text { Понимать содержание произведения в деталях, характеризовать } \\
\text { героев произведения. }\end{array}$ \\
\hline & Большинство учащихся будут уметь \\
\hline & $\begin{array}{l}\text { Понимать содержание произведения в деталях, характеризовать } \\
\text { героев,выражая своё мнение о них. }\end{array}$ \\
\hline & Некоторые учащиеся смогут \\
\hline & $\begin{array}{l}\text { Установить сходство и различие героев произведения на основе } \\
\text { анализа их речи и поступков. Сравнить героев } \\
\text { произведения,сделать выводы о необходимости духовного роста } \\
\text { молодого поколения. } \\
\text { - развивать ассоциативное и аналитическое мышление, память, } \\
\text { речь; }\end{array}$ \\
\hline & Учащиеся могут: \\
\hline & $\begin{array}{l}\text { Анализировать поступки героев, их речь, давать образную } \\
\text { характеристику персонажей, делать выводы, создавать связный } \\
\text { текст - характеристику героев на основе деталей. }\end{array}$ \\
\hline & Ключевые слова и фразы: \\
\hline & Роман в стихах,сопоставление,контраст, аристократ театр, \\
\hline & Стиль языка, подходящий для диалога/ письма в классе. \\
\hline & Вопросы для обсуждения \\
\hline & \\
\hline & - Кому из них посвящены эти строки? \\
\hline & И он убит - и взят могилой, \\
\hline & Как тот певец, неведомый, но милый, \\
\hline & Добыча ревности глухой... \\
\hline & - Что такое дуэль? \\
\hline & $\begin{array}{l}\text { - Как по-вашему, дуэль - это убийство или позволительная защита } \\
\text { чести? Аргументируйте свой ответ. } \\
\text { - Итак, на прошлом уроке мы познакомились с двумя главными } \\
\text { героями романа: Евгением Онегиным и Владимиром Ленским. А } \\
\text { теперь давайте обратимся к главным женским персонажам романа в } \\
\text { стихах «Евгений Онегин». Назовите их. }\end{array}$ \\
\hline
\end{tabular}

- Почему так много раз, описывая Татьяну, автор употребляет частицу «не», показывает, какой она НЕ была? В чем необычность Татьяны?

Подсказки: примерные ответы на вопросы:

1)Меня удивило в произведении ...

(- Почему же отвергла Татьяна любовь Онегина, если она попрежнему его любит?»:).

2) Развиваться отношения не могут, так как....

(Их разлучает то, что называется долгом, что Татьяна обозначает словами «я другому отдана», и ее долг - быть ему верной «век», до конца жизни.Татьяна и раньше так же относилась к долгу жены: вспомним, что она писала Онегину, когда еще была «девочкой несмелой).

3) Я считаю, что проблема в романе.....

(Пушкин упоминает вопрос долга и чести).

Преды-дущее Читать тексты. Изучать детали для анализа и характеристики обучение героев произведений. Отвечать на вопросы, высказывать мнение, анализировать, делать выводы. На этом уроке продолжают отрабатывать данные навыки.

\begin{tabular}{l|l} 
Цен-ности & Через изучение и анализ литературного произведения побуждать
\end{tabular} учащихся к стремлению совершенствовать себя и мир вокруг

\begin{tabular}{l|l} 
Меж-пред- & Сценическое искусство, история,русский язык.
\end{tabular}

метная связ

План.

\begin{tabular}{|l|llll|l} 
Планир & Планируемые действия ( замените записи & ниже & ресурсы
\end{tabular}

уемые

запланированными действиями)

сроки

Начало

Деление на группы по словам: олицетворение, метафора,

С., С

гипербола, эпитет, антитеза ( стикеры)

минут Мотивация.

Эдуард Успенский сказал: «Если вы хотите узнать, насколько умнее и лучше становится человек, прочитавший тысячу книг, прочитайте тысячу книгу.

Желаю вам читать всегда, читать везде и быть успешным и на

этом уроке и в жизни.

Подведение к теме урока, «Мозговой штурм»,вопросы,

подводящие к теме урока:

1.Олицетворение,метафора,гипербола,эпитет,антитеза

(цветные карточки-актуализация пройденных тем)

2..- Итак, на прошлом уроке мы познакомились с двумя главными героями романа: Евгением Онегиным и Цветны Владимиром Ленским. Друзья или враги? Анализ строф

XXVIII-XXXIV.

3.- Кому из них посвящены эти строки?

карточк

И он убит - и взят могены и- 


\begin{tabular}{|c|c|}
\hline 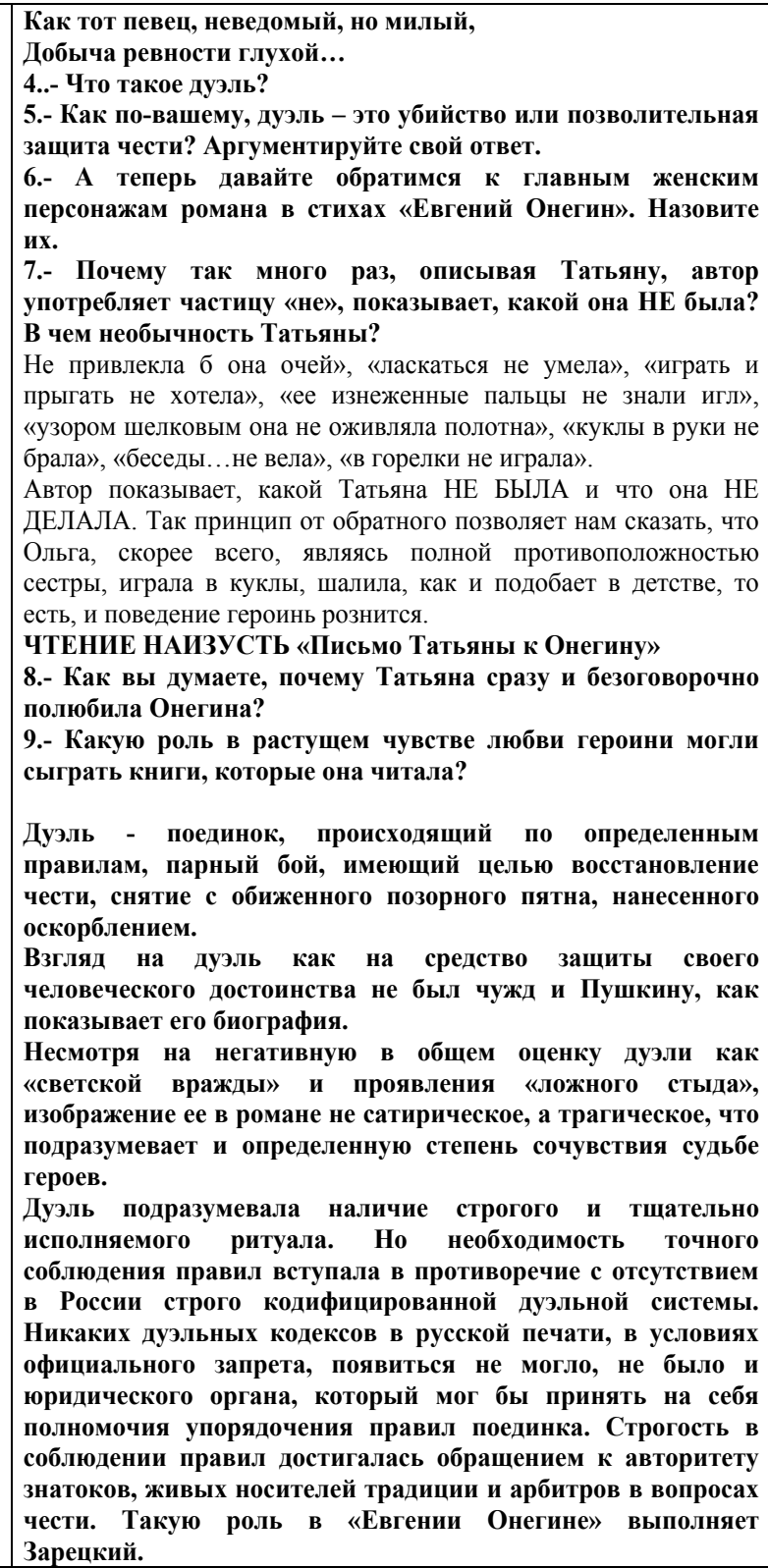 & вопросы \\
\hline
\end{tabular}

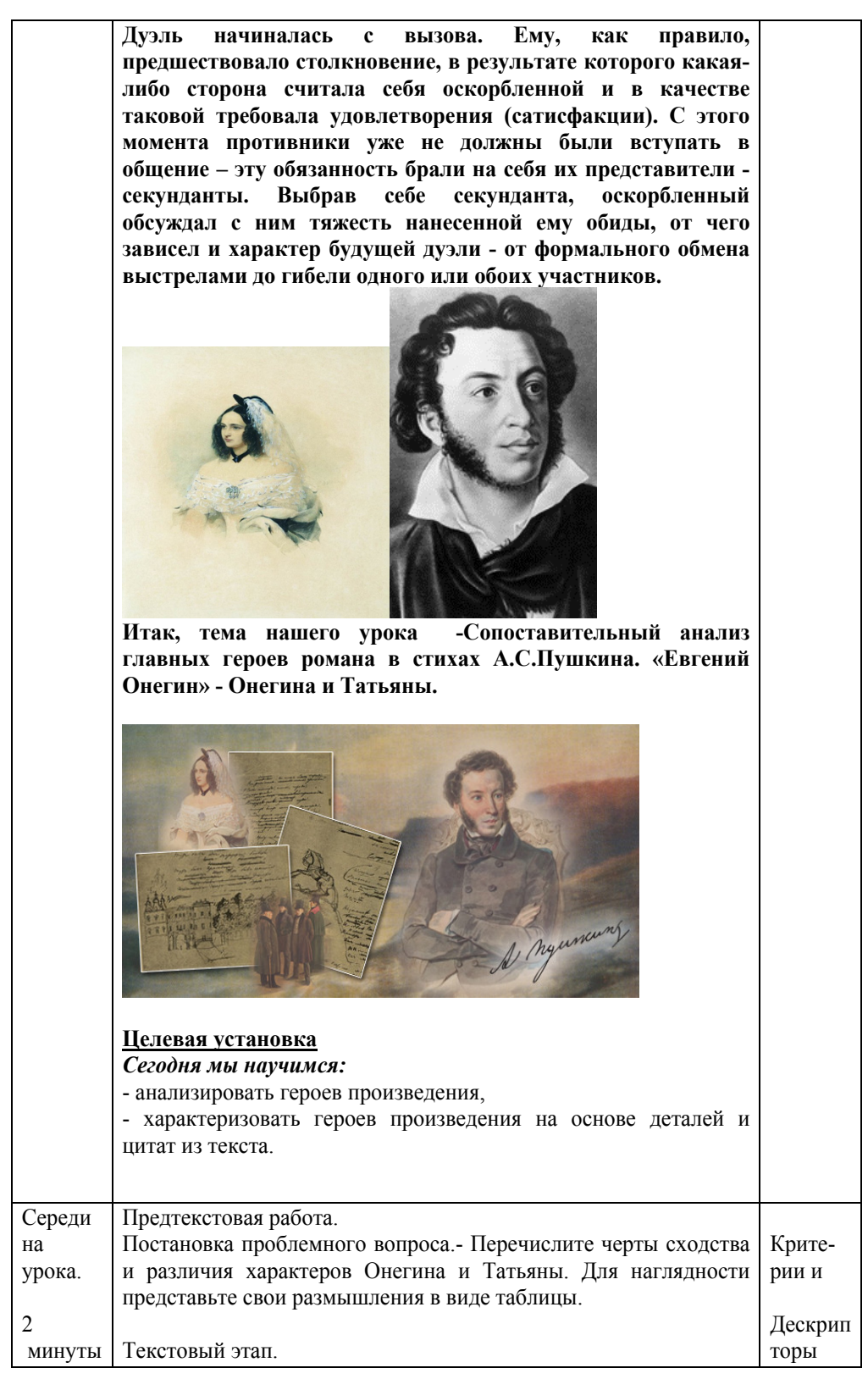




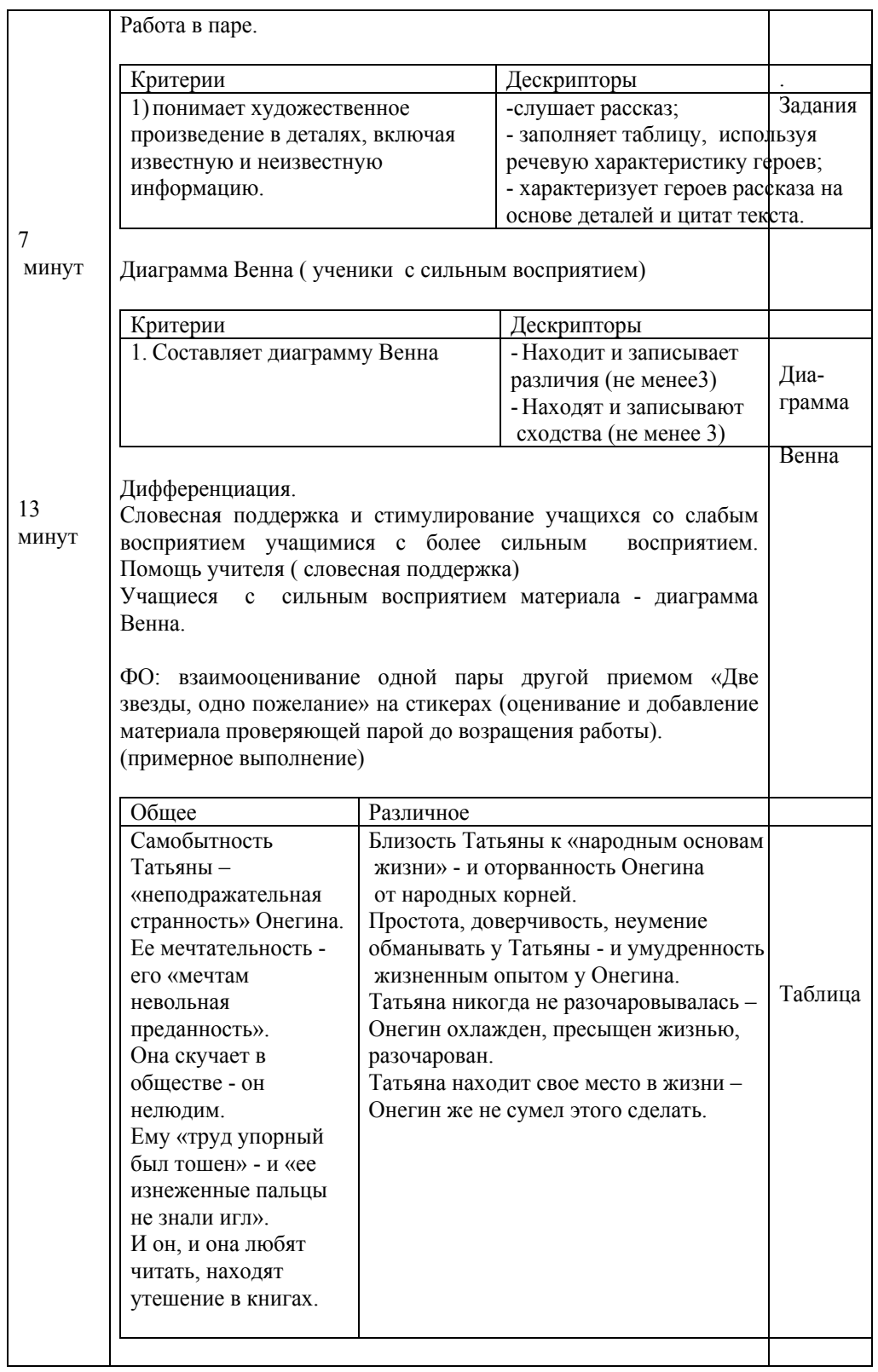

Вопросы для подведения итогов изученного произведения.В.Г. Белинский в своей статье о Татьяне писал: «Здесь не книга родила страсть, но страсть все-таки не могла не проявиться немножко по-книжному. Зачем было воображать Онегина Вольмаром, Малек-Аделем, де-Линаром и Вертером?.. Затем, что для Татьяны не существовал настоящий Онегин, которого она не могла ни понимать, ни знать

1.Как вы понимаете эти слова ?

И вот Татьяна и Онегин встретились. Что же слышит от него девушка? Этот монолог Онегина (строфы XII-XVI) литературоведы называют по-разному: исповедь, проповедь, отповедь. А как думаете вы? Аргументируйте свой ответ.

- Проповедь Онегина противопоставлена письму Татьяны совершенным отсутствием в ней литературных клише и реминисценций.

Смысл речи Онегина именно в том, что он неожиданно для Татьяны повел себя не как литературный герой («спасительи или

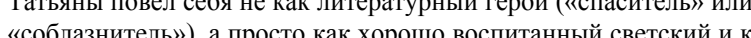
«соблан

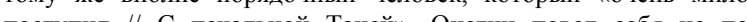

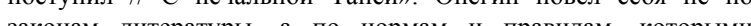
законам литературы, а по нормам и правилам, которыми руководствовался достойный человек пушкинского круга в жизни. Этим он обескуражил романпическю героию, которая была готова и к «счастливым свиданьям», и к «гибели», но не к переключению своих чувств в плоскость приличного светского поведения, а Пушкин продемонстрировал ложность всех штампованных сюжетных схем, намеки на которые были так щедро разбросаны в предшествующем тексте.

Не случайно во всех последующих строфах главы доминирующей делается тема литературной полемики, разоблачения литературных штаппов и противопоставления им райствительест, истины и прозы Олнак при всей наивности дейстительости, истины начй способноси к чувспу, огслспуюц в душе трезвого героя. 2.Какова проблема, раскрываемая автором в сопоставлении Онегина и Татьяны? Почему вы так думаете?

Пушкин упоминает вопрос долга и чести. Эту тему полностью раскрывает Татьяна Ларина. Она была, как и Евгений, дворянского происхождения, получила поверхностное воспитание в домашних условиях. Однако нравы света не повлияли на ее чистую и невинную душу. Она безумно любит Онегина, однако ставит свой долг перед мужем, хоть и нелюбимым, превыше всего. Даже страстная тирада героя не склонила ее поменять принятое решение.

3.Как вы думаете, какую задачу ставил перед собой писатель, создавая перекрестное описание отношений Татьяны и Евгения? Пушкин продемонстрировал ложность всех штампованных 


\begin{tabular}{|c|}
\hline 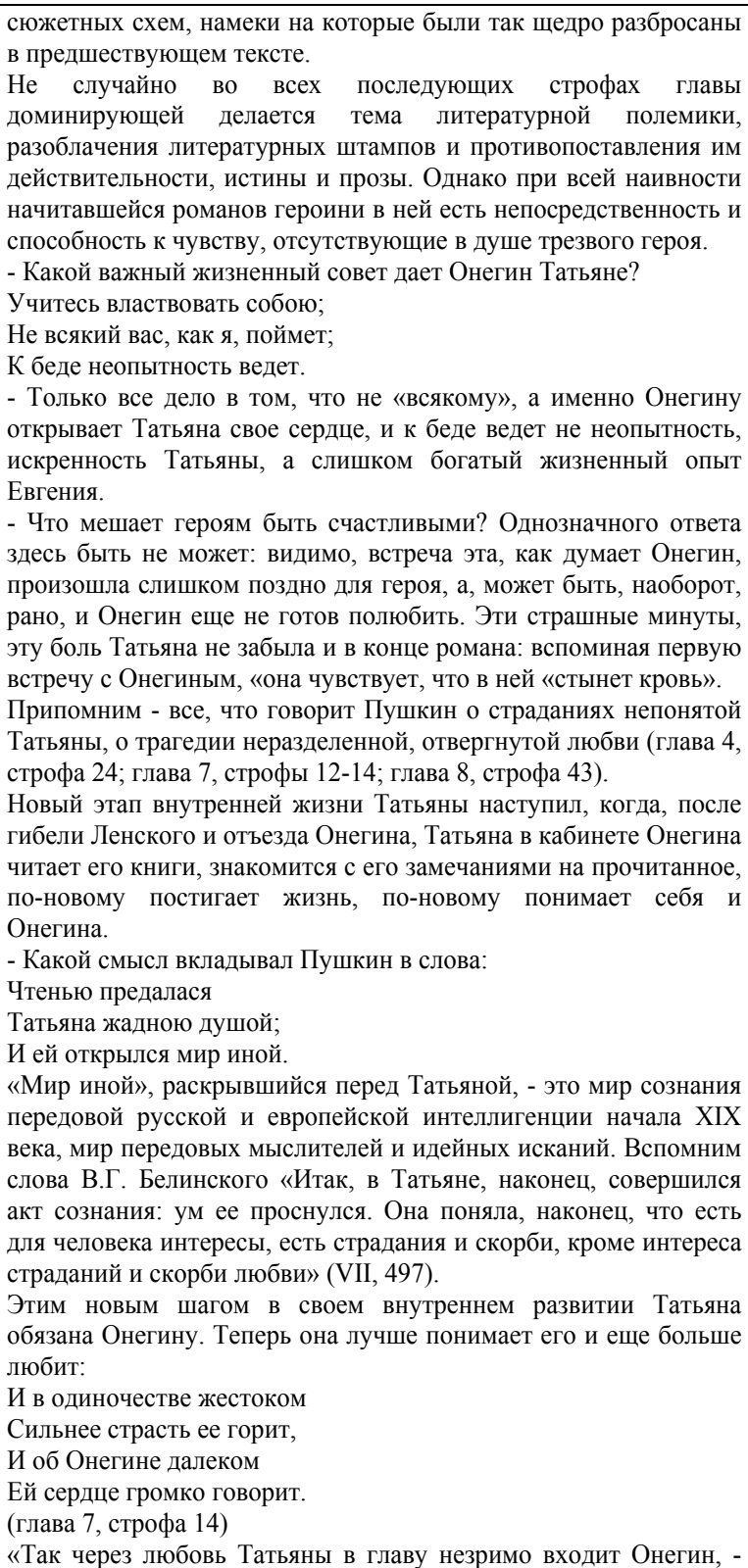 \\
\hline
\end{tabular}

комментирует эти слова Г.П. Макогоненко. - Его нет, он где-то далеко, но мы узнаем новые стороны его души». Теперь Татьяне видно, что «многое в Онегине не является особенностями его личности нЛи гапризами столичного модного «чудақа», но принадлежит времени, человеку».

Глава седьмая заканчивается встречей Татьяны в дворянском собрании с ее будущим мужем. Она становится великосветской дамой, княгиней. Между событиями седьмой и восьмой глав прошло приблизительно два года; но переход от Татьянь, провинциальной барышни, к Татьяне, важной княгине, Пушкиным не показан.

Давайте теперь поговорим о том, какой Татьяна предстает перед нами в финале романа. Какой описывает Пушкин Татьяну на светском рауте? (Строфы 14 и 15.)

Татьяна изображена здесь в духе пушкинского идеала женщины: «Все тихо, просто было в ней».

- В чем же изменилась Татьяна? (Строфы 27-28.)

7 минут Вместо «девочки несмелой, Влюбленной, бедной и простой» перед нами «равнодушная княгиня», «неприступная богин Роскошной царственной Невы». Вместо «девчонки нежной» «величавая», «небрежная законодательница зал». Глубину происшедших с Татьяной изменений подчеркивает и автор: «Как изменилася Татьяна!»

Индивидуальная работа:

Стратегия РАФТ: роль, аудитория, форма, тема.

Задание: написать письмо в виде РАФТ( ученику предлагаются роли: писателя, читателя, героя произведения, ученики сами выбирают роль и аудиторию).

\begin{tabular}{|l|l|}
\hline Критерии & Дескриптеры \\
\hline Пишет письмо в виде РАФТ & -выбирает роль \\
& - выбирает аудиторию \\
& - соблюдает структуру и жанр \\
\hline
\end{tabular}

Дифференциация.

Предусматриваются виды дифференциации: итоги, выбор роли, поддержка учителя

Оценивание учителя

Задание на дом:

-Напишите эссе-рассуждение (200-250слов),на тему:» Татьяна

любимая героиня А.С.Пушкина.»

Подготовьтесь к дискуссии на тему «Актуально ли творчеств А.С. Пушкина в наши дни?» 
Министерство образования и науки Республики Казахстан Западно-Казахстанский инновационно-технологический университет

\title{
КУЗНЕЦОВА А.Н.
}

Диалог: содержание и форма педагогической деятельности

\author{
Уральск, 2021
}

Бумага офсет. Формат 60x84/16.

Подписано в печать 31.03.2021. Объем 10,5 усл.п.л.

Тираж 1000 экз.

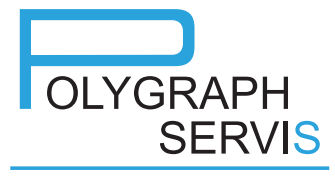

ТИПОГРАФИЯ

Отпечатано в типографии ТОО «Полиграфсервис».

г.Уральск, ул. Л.Толстого, 27/6. Тел.факс: 8 (7112) 50-51-46, 51-41-99. 